Andrews University

Digital Commons @ Andrews University

1995

\title{
A Series of Sermons and Growth Experiences in Marital Covenant Love Relationships in the Ottawa East Seventh-day Adventist Church
}

Vaudré Pierre Jacques

Andrews University

Follow this and additional works at: https://digitalcommons.andrews.edu/dmin

Part of the Practical Theology Commons

\section{Recommended Citation}

Jacques, Vaudré Pierre, "A Series of Sermons and Growth Experiences in Marital Covenant Love Relationships in the Ottawa East Seventh-day Adventist Church" (1995). Professional Dissertations DMin. 641.

https://dx.doi.org/10.32597/dmin/641

https://digitalcommons.andrews.edu/dmin/641

This Project Report is brought to you for free and open access by the Graduate Research at Digital Commons @ Andrews University. It has been accepted for inclusion in Professional Dissertations DMin by an authorized administrator of Digital Commons @ Andrews University. For more information, please contact repository@andrews.edu. 


\section{ABSTRACT}

A SERIES OF SERMONS AND GROWTH EXPERIENCES IN MARITAL COVENANT LOVE RELATIONSHIPS IN THE OTTAWA EAST SEVENTH-DAY ADVENTIST CHURCH

Vaudré Pierre Jacques

Adviser: James J. North, Jr. 


\section{ABSTRACT OF GRADUATE STUDENT RESEARCH \\ Project Report}

Andrews University

Seventh-day Adventist Theological Seminary

Title: A SERIES OF SERMONS AND GROWTH EXPERIENCES IN MARITAL COVENANT LOVE RELATIONSHIPS IN THE OTTAWA EAST SEVENTH-DAY ADVENTIST CHURCH

Name of researcher: Vaudré Pierre Jacques

Name of degree of faculty adviser: James J. North, D.Min. Date completed: May 1995

\section{Problem}

In my interactions with my church members or more precisely with married couples, I have become aware of their idiosyncrasies in the realm of marital conflicts. It is hoped that this project will help to salvage marriages. However, this project is written from a preventive stance.

\section{Method}

In this project, a theological basis for marital covenant relationship was developed. Second, a series of five sermons and five growth seminars were conducted with some married couples and persons contemplating marriage. 
Third, pre- and post-questionnaires were distributed in order to assess the understanding of what is being discussed.

\section{Results}

From the comments that were made, the program seemed to have been a success. Couples expressed improved mutual understanding and a desire to learn more. The participants reached a better understanding of mutual intimacy, effective communication, mutual forgiveness, and marital maturation. The participants learned that every relationship has its problems, but they should control those difficulties.

\section{Conclusion}

A successful intimate relationship is a precious thing, well worth investing time and energy to protect it. The couples found that with practice, a few skills, and a willingness to change and to improve their life together, they can enjoy a more peaceful, lasting, and fun-filled marriage. Good marriages do not just happen. They may be created in Heaven but must be lived on earth. This project helps couples maintain, refine, and enhance their marriages. 
Andrews University

Seventh-day Adventist Theological Seminary

A SERIES OF SERMONS AND GROWTH EXPERIENCES IN MARITAL COVENANT LOVE RELATIONSHIPS IN THE

OTTAWA EAST SEVENTH-DAY ADVENTIST CHURCH

\author{
A Project Report \\ Presented in Partial Fulfillment \\ of the Requirements for the Degree \\ Doctor of Ministry
}

by

Vaudré Pierre Jacques

May 1995 



\section{A SERIES OF SERMONS AND GROWTH EXPERIENCES IN MARITAL COVENANT LOVE RELATIONSHIPS IN THE OTTAWA EAST SEVENTH-DAY ADVENTIST CHURCH}

A project report

presented in partial fulfillment of the requirements for the degree

by

Vaudré Pierre Jacques

APPROVAL BY THE COMMITTEE:
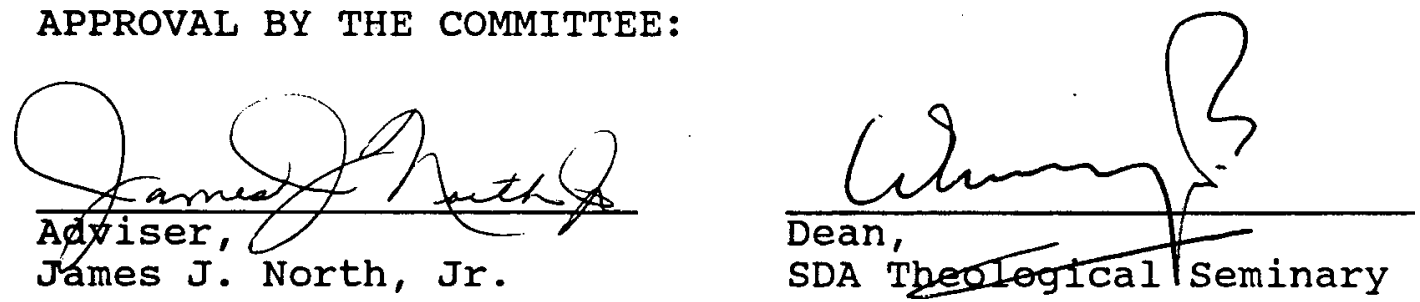

Woecen B.T. Do ugles

Walter B. T. Douglas

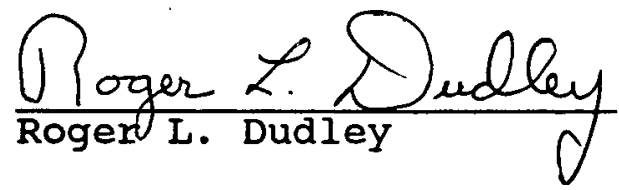

$\frac{\text { May } 24,1995}{\text { Date approved }}$ 
TABLE OF CONTENTS

ACKNOWLEDGMENTS . . . . . . . . . . . . . . . . i i

INTRODUCTION . . . . . . . . . . . . . . . . . 1

Purpose of the Project............... . 1

Justification for the Project ........... 1

Description of the Project . . . . . . . . . 6

Expectation from the Project . . . . . . . . . 7

An Overview of the Project . . . . . . . . . . . . 8

Chapter

I. THEOLOGICAL FOUNDATION OF MARITAL/

COVENANT LOVE . . . . . . . . . . . . . . 10

Introduction ............. . 10

The Meaning of the Word Covenant ..... . 11

The Marriage Covenant . . . . . . . . 21

II. COVENANT LOVE AND INTIMACY . . . . . . . . 35

Part one: The Meaning of Intimacy . . . . . 38

Part Two: The Intimacy Principle . . . . . 40

Leaving and Cleaving.......... 43

Severance .............. . 44

Permanence .............. 45

Unity . . . . . . . . . . . . . . . . . 46

Part Three: Building and Maintaining 47

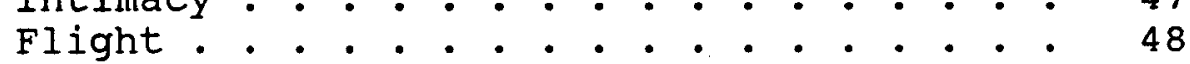

Diversion ............. . 49

Fighting . . . . . . . . . . . . . . 49

Compromise . . . . . . . . . . . . 50

"Smooth" . . . . . . . . . . . . 50

Withdrawal . . . . . . . . . . 50

Confrontation ............. . 50

Seeking Help... . . . . . . . . . 50

Constructiveness . . . . . . . . . . 50

Part Four: The Marital Pyramid . . . . . . 51

Stages of Intimacy . . . . . . . . . 56

The romantic/honeymoon stage .. . . 56

The conflict/power struggle stage . . 57

The interdependence stage . . . . . . 59

The full commitment stage . . . . . 60 
Part Five: Intimacy Brings Satisfaction . .

III. COVENANT COMMUNICATION . . . . . . . . . . 64

Part one: The Importance of covenant

Communication ............ 66

Part Two: Effective Communication . . . . 68

Part Three: Characteristics of Good

Communication .......... . 70

Part Four: Obstacles to Covenant Communication ............. 73

One Example of Ineffective Communication . 74

One Example of Effective Communication . . 75

Three Hindrances to an Effective

Communication ......... . . 77

Part Five: Techniques for Enhancing

Covenant Communication . . . . . . . 77

Five Techniques for Exploring Your

Partner's viewpoint ....... . . 80

IV. COVENANT FORGIVENESS . . . . . . . . . . . 83

Part one: What Is Forgiveness? . . . . . 85

Giving Up ................ . 86

Giving Notice ............ . 87

Giving Gifts....... . . . . . . . 87

Part Two: The Process of Forgiveness . . . . 89

Naming the Injury . . . . . . . . . . . 89

Claiming the Injury . . . . . . . . . . 91

Blaming the Injurer ... . . . . . . 92

The Objective of Blaming . . . . . . . . 93

Restitution: Balancing the Scales... . 95

Choosing to Forgive . . . . . . . . 98

The Emergence of a New Self . . . . . 101

Part Three: Biblical Forgiveness . . . . . 102

How to Forgive... . . . . . . . . 102

Unlimited Forgiveness . . . . . . . . 104

Receiving and Extending Forgiveness . . 105

Forgiveness in Word and Action . . . . . 106

Part Four: Covenant Forgiveness as

Therapy . . . . . . . . . . 110

V. SURVIVAL TECHNIQUES FOR ENHANCING

MARITAL COVENANT LOVE . . . . . . . . . . . 117

Introduction . . . . . . . . . . . . 117

Part One: Hindrances to Marital
Covenant Love ...... 117

Lack of knowledge . . . . . . . . . . 119

Lack of Love Expression . . . . . . . 120

Lack of Adaptation to Different

Stages of Life .......... . 121

Lack of Spiritual and Moral Communion . . 123

Lack of Intimacy . . . . . . . . . . 124 
Prolonged Absence . . . . . . . . . 125

Outside Influences . . . . . . . . . 126

Part Two: Techniques for Enhancing

Marital Covenant Love . . . . . . . 136

VI. COVENANT CHRISTIAN MATURITY • • • • . • . • • 155

Introduction . . . . . . ....... . 155

Part one: The Necessity of Christian

Maturity . . . . . . . . . . . . 156

Part Two: Four Essential Elements to

Maturity . . . . . . . . . . . . 159

Part Three: The Characteristics of the

Spiritually Mature Person . . . . . . 160

Part Four: The Pyramid of Christian

Maturity ............. . . . 161

Part Five: Four Kinds of Love . . . . . . . 162

Part Six: Signs of Maturity in Ourselves

and others ............... . 164

Part Seven: Seven Guidelines for Attaining Christian Maturity . . . . . . . . 168

VII. DESCRIPTION OF SEMINARS • . . . . . . . • • • . 180

Seminar \#1 . . . . . . . . . . . . . 180

Seminar \#2 . . . . . . . . . . . . . . . 181

Seminar \#3 . . . . . . . . . . . . . . . 182

Seminar \#4 . . . . . . . . . . . . . 182

Seminar \#5 . . . . . . . . . . . . . . 183

VIII. EVALUATION, SUMMARY, CONCLUSIONS,

AND RECOMMENDATIONS • • . . . . . . . . . . . . 184

Evaluation . . . . . . . . . . . . . 184

The Questionnaire Results . . . . . . 184

Summary . . . . . • . . . . . . . 185

Conclusion . . . . . . . . . . . . . 187

Recommendations . . . . . . . . . . . 188

APPENDIX 1 .

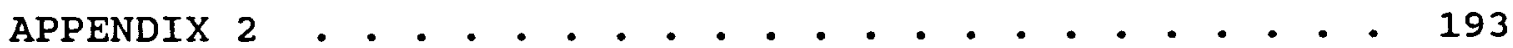

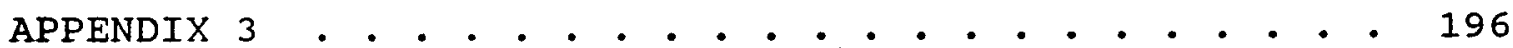

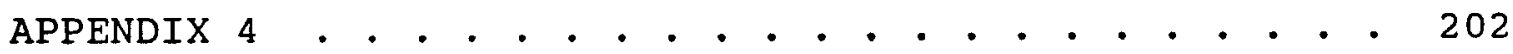

APPENDIX 5 . . . . . . . . . . . . . . . . . . 206

BIBLIOGRAPHY • • • • • . . . • • • . . . • • . 316

VITA 


\section{ACKNOWLEDGEMENTS}

For the successful completion of this project, I am indebted to several persons, only a few of whom it is possible to mention here. Indirectly, I feel indebted to many authors who have written valuable studies on the subject of marital problems and solutions. Directly, I want to express my deepest gratitude to Dr. James North, my adviser, from whom I have received continual insight and support, and who has guided me through the project.

I also want to thank Frank Campbell who has read most of the material and has made helpful corrections. Various persons have assisted in the typing. One of them, Bonnie Beres, although a full-time secretary in the Christian Ministry Department in the Theological Seminary, found the time to skillfully type the complete work. Jan Higgins, the Doctor of Ministry secretary, has greatly encouraged me through her kindness and the practical information she provided on the timing of the project. My thanks also go to Drs. Walter Douglas and Roger $L$. Dudley for reading the material and reacting constructively to it.

I dedicate this project to Gladys, my wife, and to my children, Danielle and Patrick. They have sustained me with 
the love and delight of family life during my years in the Doctor of Ministry program.

Above all, I thank God the Father, Jesus Christ my Saviour, and the Holy Spirit my Comforter, who helped see me through. It is my deepest hope that this project--the fruit of a profound conviction that God wants every married couple to experience lasting marital happiness--may contribute to the enhancement of conjugal satisfaction in many homes. 


\section{INTRODUCTION}

\section{Purpose of the Project}

The purpose of this project was to develop and

preach five sermons on the hindrances that undermine marital covenant love relationships and hold five growth sessions on how to overcome them. The project was implemented in the Ottawa East Seventh-day Adventist Church.

\section{Justification for the Project}

The most important pastoral functions are teaching and preaching. Couples need both. They need to be reminded that a successful marriage does not just happen. It is the result of continual commitment and improvement. Couples in the church must be taught to be intentional about the success of their marriages. There needs to be an emphasis on the biblical concept of marital covenant love, the heart of marriage itself. This is the urgent task of those of us who believe in God and believe in marriage.

Moreover, it is an undeniable fact that christian marriage is in trouble in today's society. Divorce is rampant. Many unhappy couples stay together mostly for the sake of the children. Widespread frustration with marriage 
lessens the power of morality or religion to hold things together. Harville Hendrix remarks that

we have bought the idea that unhappy people should not have to stay in unhappy marriages. We have given credence to the idea that when trouble comes you should just change partners, when the truth is that the way you are living with that person must be changed. ${ }^{1}$

Several unhappy married couples confessed to me that "what they want is not a change of partners, but a change in the behavior of their partners." Rather than getting rid of the partner and keeping the problem, couples should get rid of the problem so that they can keep the partner. Divorce is not the best solution to resolving marital difficulties.

Divorce is not a disease; it is a symptom. Society is sick and in danger of losing its soul. The childish notion that the accumulation of material possessions and the instant gratification of desires constitute the royal road to happiness lies at the root of most of the dislocations of contemporary life, including drugs, crime, and the corruption of our political and economic order. ${ }^{2}$

Erosion of genuine values threatens to destroy the family by subverting the institution of marriage--an institution that has, for most of recorded history, been the best instrument yet discovered for the protection of children, the socialization of their behavior, and the

\footnotetext{
${ }^{1}$ Harville Hendrix, Keeping the Love You Find (New York: Pocket Books, 1992), 22 .

${ }^{2}$ Robert Gordis, Love and Sex: A Modern Jewish Perspective (New York: McGraw-Hill Ryerson, 1978), 122.
} 
satisfaction of the physical and emotional needs of men and women. ${ }^{1}$

One moral imperative of Christianity is to strive to re-establish the sense of the sanctity of marriage as the noblest condition available to a man and woman. only a lifelong process of education can avail. The example of the loving home will prove far more efficacious than formal teaching in the classroom and eloquent preachment in the pulpit.

If there could be a nationwide recognition of the need to reeducate ourselves about relationships, marriages would survive and prosper, our children would be healthier, and we wouldn't need 80 percent of the remedial programs now dealing with the end products of unloved children--whether they be drugs, violence, incest, child abuse, high dropout rates, thievery, alcoholism, or teenage pregnancy. ${ }^{2}$

God knows divorce is not the answer. "I hate divorce, says the Lord God of Israel" (Mal 2:16). ${ }^{3}$ Divorce is the acid test of marriage, the litmus paper revealing the stresses and strains that threaten the survival of the divine institution. With the proportion of divorces to marriages in North America reaching one in three, it is clear that marriage as the basic pattern of male-female relationships is in jeopardy.

'Ibid., 123.

${ }^{2}$ Hendrix, 23.

${ }^{3}$ Unless stated otherwise, the version of the Bible used in this paper is the New International Version (NIV). 
We are learning, too, that no matter how easy we make it, the children of divorce carry lasting scars. Divorce may allow people to escape from bad marriages, but until we take steps to ensure good marriages, to facilitate individual happiness and fulfillment, until we learn what we are about, we will continue to have desperate singles, joyless marriages, troubled children, and a society becoming more dysfunctional by the decade. ${ }^{1}$

All resources must be mobilized in order to inculcate an ideal of marriage that will reckon with human limitations. Nothing less will rescue humankind from the morass of degradation and misery into which it is being plunged today.

The pastor skilled in pastoral counseling has a vantage point. Because the pace of marriage breakup is increasing the Christian pastor needs wisdom, theological insight, and compassion in sharing in and ministering to a difficult and complex situation.

Samuele Bacchiocchi observes that the church can play an important role in preventing marriage breakups in these common situations. First, through counseling, a pastor trained not only theologically but also in counseling skills can help a couple having marital conflicts to understand how to resolve their differences constructively, not by seeking divorce but by improving their communication skills. ${ }^{2}$

${ }^{1}$ Ibid.

${ }^{2}$ Samuele Bacchiocchi, The Marriage Covenant (Berrien Springs, MI: Biblical Perspectives, 1991), 218. 
The church is called to be an agent of reconciliation and forgiveness. Its mission also includes proclaiming and creating the possibility for the living out of God's will for marriage.

While I venture to hope that this project is based on solid scholarship and reflects a firsthand knowledge of what is happening in churches and society, it is not an academic treatise on marital conflicts. Rather, this project has a threefold purpose. The first is to help couples in my church become conscious of some of the hindrances that undermine marital covenant love relationships. I want them to become conscious of the fact that they do not have to leave marriage in order to grow and change. Powerful healing is possible through marriage. The Lord God said, "It is not good for the man to be alone. I will make a helper suitable for him" (Gen 2:18). Marriage is not so much a rigid institution as it is the framework within which a dynamic process takes place. Marriage itself, properly understood, is the therapy we need to grow and become whole, to return to our innate joyful state. ${ }^{1}$

The second is to provide couples with some techniques that will help them enhance their marital covenant love relationship. Couples can and will resolve their conflicts if there is some mutual good-will, comprehension and tenderness--if they make Jesus christ the object of their affections. "I can do everything through

\footnotetext{
${ }^{1}$ Hendrix, 23.
} 
him who gives me strength" (Phil 4:13). "Apart from me you can do nothing" (John 15:5).

The third is to encourage growth and maturity in Christian marriage. Our lives inevitably head for a fall if we do not accept responsibility for the part we have played in our problems and accept that all humans have strengths and weaknesses. The real mistake lies not in committing an error, but in failing to learn from it.

Every mistake can be the signal for a new step toward therapeutic competence, if it is recognized, analyzed, and used for growth. Don't be complacent about your mistakes. They are not good, and nobody likes to make them. However, don't magnify them out of proportion, either. Like rocks in a stream, they can be used to trip and fall over or as a bridge to a new and better ife. ${ }^{1}$

\section{Description of the Project}

The Bible and the writings of Ellen $\mathrm{G}$. White and other relevant material were explored and used as a theoretical foundation for this project.

The project was divided into three parts:

1. Sermons: A series of five different sermons were preached. The themes included: Covenant Love and Intimacy; Covenant communication and the Practice of Christian Qualities; Covenant Forgiveness; Covenant Techniques for Enhancing Marital Love; Covenant Maturity Techniques for a Lasting Marriage.

${ }^{1}$ Janet Moursund, The Process of Counselling and Therapy (Englewood Cliffs, NJ: Prentice-Hall, 1990), 213. 
2. Fellowship dinners following each worship service.

3. Five afternoon seminars: The afternoon sessions were designed mainly for fifteen married couples but couples contemplating marriage were allowed to attend. Most of the material used in the seminars was taken from the project itself in the form of transparencies, feedback, and input from the couples.

A pre-questionnaire was distributed at the beginning of the seminar and a post-questionnaire at the end to assess the understanding of what was discussed. (See the appendices.)

\section{Expectation from the Project}

The overall goal is to provide married couples with the needed insights and skills that enable them to deal more effectively with problems in marital life. This project will help Christian couples to become conscious of those hindrances that block marital happiness and hinder christian growth and maturity.

The participants will learn that all is not lost in an estranged relationship. There is something on which one can rekindle a relationship. The participants will learn to tell how they feel without speaking malicious remarks which they will later regret. Since marital life is under the umbrella of biblical teaching, all other christian teachings concerning kindness, patience, humility, sobriety, industry, 
self-sacrifice, and gentleness apply with special force in the marriage relationship. In a nutshell, the participants will learn how and why to avoid cul-de-sac approaches, winlose situations.

It is hoped that this project will enable other pastors likewise to be pro-active in enriching marriages in their churches and bringing a decrease in marital break up in the church.

\section{An Overview of the Project}

Chapter 1 of this paper explores the basic concepts underlying the project: biblical covenant love relationships and the essential characteristics of covenant love relationship between God and His children and between husbands and wives.

Covenant relationships induce freedom, not paralysis. A covenantal relationship rests on shared commitment to ideas, to issues, to values, to goals, and to management process. Words such as love, warmth, personal chemistry, are certainly pertinent. Covenant relationships . . fill deep needs and they enable work to have meaning and to be fulfilling.

Chapter 2 deals with love and intimacy in marital covenant love relationships. We get out of our marriage what we put into it. It considers negative elements undermining covenant love and intimacy and how to deal with them. The objective in this part is to see how it is

${ }^{1}$ Bennis Warren, on Becoming a Leader (Addison, IL: Wesley Publishing Co., 1989), 158. 
important to maintain love and romance in marriage by knowing the different stages of intimacy.

Chapter 3 deals with the importance of effective communication in marital covenant love. Good communication does not just happen; husband and wife have to desire it, work at it, re-evaluate it, and consistently maintain it. Lack of effective communication affects marital and family functioning. Lack of adequate communication impedes marital adjustment and problem-solving in the family.

Chapter 4 deals with the benefits of forgiveness. The lack of forgiveness affects not only the home but also the church family. An unforgiving spirit can affect the health of the partners.

Chapter 5 addresses the core of this paper. It is divided into two sections. The first portion looks into the major hindrances to marital covenantal love. The second portion proposes basic techniques that can turn marital conflicts into opportunities for building a better, durable marriage.

Chapter 6 examines maturation in marriage. The ultimate end in marital covenant love is the attainment of completeness in Christ. Marital covenant love is a long process that includes struggles. 
CHAPTER 1

THEOLOGICAL FOUNDATION OF

MARITAL/COVENANT LOVE

\section{Introduction}

My goal is to begin to elucidate a theology of the marriage covenant. This is not a study of biblical texts relating to covenant love. My purpose, rather, is to examine the broader theological question: "What are the essential characteristics of a covenant love relationship between God and His children and between husbands and wives?"

I address this question by considering, first of all, the covenant relationship between God and His people. This understanding is to be an integrative model. I make use of knowledge derived from biblical data, Ellen G. White, and other relevant sources.

The primary task, however, remains a theological

one. I think Emil Brunner was correct when he wrote, "Man must first of all be defined theologically; only then may 
the philosopher, the psychologist, and the biologist make their statements." 1

\section{The Meaning of the Word Covenant}

The Greek word of covenant is diatheke. In the Septuagint, diatheke is the equivalent to the Hebrew word berit. The word covenant may be defined as:

A solemn promise made binding by an oath, which may be either a verbal formula or a symbolic action. Such an action or formula is recognized by both parties as the formal act which binds the actor to fulfill his promise. Covenants may be between parties of different socio-political groups, in which case the covenant creates a relationship between them regulated by the terms of the covenant; or a covenant may take place within a legal community, in which case obligations are assumed which the law does not provide for, i.e., it makes new obligations binding. ${ }^{2}$

In the vast majority of occurrences of berit, the LXX renders it with diatheke, which in Greek ordinarily (and very frequently) meant "last will and testament." ${ }^{3}$ It denotes, therefore, an irrevocable decision, which cannot be cancelled by anyone. A prerequisite of its effectiveness before the law is the death of the disposer. Hence, diatheke must be clearly distinguished from syntheke, an agreement. ${ }^{4}$

\footnotetext{
${ }^{1}$ Emil Brunner, Man in Revolt: A Christian Anthropology (Philadelphia: Westminster, 1939), 102.

${ }^{2}$ The Interpreter's Dictionary of the Bible (1962), s.v. "diatheke."

${ }^{3}$ Ibid., 716.

${ }^{4}$ The New International Dictionary of New Testament Theology (1975), s.v. "syntheke."
} 
Balz and schneider point out in their comment on the word diatheke:

In all instances the emphasis lies on irrevocable commitment. This is indeed the case for diatheke in the sense of last will and testament. What is of significance is that what is irrevocable is valid (Gal. 3:15), coming to be "in force" after death (Heb. 9:17). God has firmly obligated himself to his people in his holy covenant promise to Abraham (Luke 1:72f.).1

The relationship of the partners in the covenant is expressed by hesed, God's covenant loyalty (RSV, steadfast love; NEB, love, loyalty, constancy). 1 Sam 20:8 understands it as protective action. Man's remembrance of the covenant expresses itself in action (Ps 103:17f.).2

The LXX assumes that diathèkè expresses the essential content of berit. The King James translates berith as "covenant" 260 times. The word is used of "agreements between men," as with Abraham and Abimelech (Gen 21:32): "Thus they made a covenant at Beer-sheba." David and Jonathan "made a covenant" of mutual protection that would be binding on David's descendants forever (1 Sam 18:3; $20: 8,16-18,42)$. In these cases, there was "mutual agreement confirmed by oath in the name of the Lord." Sometimes there were also material pledges (Gen 21:28-31). ${ }^{3}$ s.v. "hesed."

${ }^{1}$ Exegetical Dictionary of the New Testament (1990),

${ }^{2}$ The New International Dictionary of the New Testament, s.v. "hesed."

${ }^{3}$ Nelson's Expository Dictionary of the Old Testament (1980), s.v. "berith. 
The great majority of occurrences of berith are God's "covenants" with men, as in Gen $6: 18$ above. The verbs used are important. "I will establish my covenant" (Gen 6:18), literally, "cause to stand" or "confirm." "I will make my covenant" (Gen 17:2, RSV). ${ }^{1}$

"Covenant" is parallel or equivalent to the Hebrew words dăbăr ("word"), hōg ("statute"), and chesed ("lovingkindness") (Deut 7:9, NASB). These words emphasize the authority and grace of God in making and keeping the "covenant," and the specific responsibility of man under the covenant. The words of the covenant were written in a book (Exod 24:4, 7; Deut 31:24-26) and on stone tablets (Exod $34: 28) .^{2}$

People "enter into" (Deut 29:12) or join (Jer 50:5) God's covenant. They are to obey (Gen 12:4) and observe carefully all the commandments of the covenant (Deut $4: 6$ ). But above all, the covenant calls Israel to "love the Lord thy God with all thine heart, and with all thy soul, and with all thy might" (Deut 6:5). God's covenant is a relationship of love and loyalty between the Lord and $\mathrm{His}$ chosen people. ${ }^{3}$

The Bible indicates that God's covenant is central to the entire Holy Scripture. The Bible relates God's

$$
\begin{aligned}
& \text { I'Ibid. } \\
& { }^{2} \text { Ibid. , } 83 . \\
& { }^{3} \text { Ibid. }
\end{aligned}
$$


covenant purpose, that man may be joined to Him in loving service and know eternal fellowship with Him through the redemption that is in Jesus Christ. ${ }^{1}$

The question resounds, What then is a covenantal love relationship between God and His people?

When God enters into a covenantal relationship with people, He sovereignly institutes a life and death bond. A covenant is a bond in blood, or a bond of life and death, sovereignly administered. ${ }^{2}$ Extensive investigation into the etymology of the old Testament term for "covenant" has proven inconclusive in determining the precise meaning of the word. Yet the contextual usage of the term in scripture points rather consistently to the concept of a "bond" or "relationship." It is always a person who makes a covenant. still further, with few exceptions it is another person who stands as the other party of the covenant. The result of a covenant commitment is the establishment of a relationship "in connection with," "with," or "between" people."

The prominence of oaths and signs in the divine covenants underlines the fact that a covenant in its essence is a bond. A covenant commits people to one another. ${ }^{4}$

${ }^{1}$ Ibid.

${ }^{2} 0$. Palmer Robertson, The christ of the covenants

(Grand Rapids, MI: Baker Book House, 1980), 4 .

'Ibid. , 6 .

${ }^{4}$ Ibid. 
As stated above, the word covenant (berit) is a central theme in the old Testament theology--the essence of its teaching on God.

First of all, the word alliance or covenant appears in Gen $6: 18$; later it marks out the principal relationship stages of God with His people (Gen 15:18; 17:1; Exod 2:24).

It is also worthy to note the verbs used in concert with the word covenant. There are three important ones; each has its particular import. The verb karat means "to cut" (Gen 15:18). Another verb, gum, "to establish" (Gen $6: 18$ ), means to fulfill, to execute (what has been promised). The third one, natan, "to place or nominate" (Gen $6: 18$ ) underlines the bond of the covenant.

This closeness of relationship between oath and covenant emphasizes that a covenant in its essence is a bond. By means of the covenant, persons become committed to one another. ${ }^{1}$ The presence of signs in many of the biblical covenants also emphasizes that the divine covenants bind people together. The token of the rainbow, the seal of circumcision, the sign of the Sabbath--these covenantal signs enforce the binding character of the covenant. ${ }^{2}$

God enters into covenant with $\mathrm{His}$ people because He loves them. He wants them to take part in His work. He makes a covenant with them in which He offers the

\footnotetext{
${ }^{1}$ Ibid. , 7.

${ }^{2}$ Ibid.
} 
essentials: love, blessing, protection, life eternal. In return, He demands that they trust and obey Him for their own benefit.

For the Israelites, a berith signifies a communal relation between two parties with resultant rights and duties. The result is peace, salom, well-being. In the tribal way of life, people relied on blood or on a berith. It regulated private life (1 Sam 18:1-4), public life (2 Sam 5:5:1f.), and even relations with foreign tribes (2 Kgs $5: 15-32)$. It was not an acknowledgement of equality. It was considered a holy thing since it was done under the deity, Baal-Berith, El-Berith (Judg 9:4,46) who punished the violators. It was fulfilled with an oath and the pronouncement of a curse. It was concluded with the performance of prescribed rites, related to blood, originally perhaps mixing blood.

Since the blood is the seat of life (Lev. 17:14; Deut. 12:23), by mingling their blood the members of a covenant would then become one soul, and blood relationship would be effected symbolically. ${ }^{1}$

Another rite was to cut the sacrificial victims in pieces so those entering into the covenant could pass between them. This indicated a willingness to undergo this

${ }^{1}$ William Doane Kelly, quoted in Louis Hartman, Encyclopaedic Dictionary of the Bible (New York: McGrawHill Publishing Co., 1963), 160. 
fate if they broke the covenant. This is probably the origin of "to cut a covenant" (Gen 15:9-20; Jer 34:18f.)." The deity can also be one of the parties of the covenant. The covenant of Yahweh with Israel is always due to God's gracious initiative (Gen 15:9-18; Exod 19:4-6). If the people take the initiative, it is always to renew former obligations neglected or forgotten. "The covenant obliges Israel to honor Yahweh alone, . . and to keep all His moral laws and commands as the condition of divine protection (Exod 19:5; 34:15)."12

The content of the covenant is summed up in the "formula" of election. You Israel are my people and I am your God (Hos 2:23; Jer 7:23; Ezek 11:20). Israel belongs exclusively to Yahweh and is His special possession ( 1 Sam 10:1; Exod 19:6; Deut $7: 6)$.

The Bible mentions several covenants:

1. Gen 9:8-17 tells of a covenant after the deluge, the sign of which was a rainbow in the clouds. This requires faith from Noah and his descendants and included a prohibition against drinking blood. ${ }^{3}$

2. A covenant with Abraham guarantees the possession of Canaan; its sign is circumcision (Gen 17:10, 11).

'Ibid., 168 .

${ }^{2}$ Ibid.

${ }^{3}$ Ibid. 
3. The covenant of Sinai (Exod 19-24) is called the "old covenant" (2 cor $3: 14)$.

4. Deut 29:1 states that a second covenant is made by Moses in the plains of Moab, east of the Jordan (Deut $4: 44,45 f$.$) .$

5. The covenant of Josh 24:1-28 tells of a solemn covenant at sichem. Joshua urged the people to decide on whose side they were.

6. King Josiah assembled the people in Jerusalem in 622 B.C., read a rediscovered book of the law, and made a covenant to serve Yahweh and keep the laws (2 Kgs 23:1-3f.)

7. After the exile, Nehemiah read the book of the law of Moses to the people, which they bound in writing. From what has been said, one can draw the following conclusion:

Thus the entire history of mankind and especially that of the chosen people is represented as the working out of a plan of salvation carried out by God through a series of covenants that demonstrates His constant grace and protection (Pss 105:8ff.).'

According to Louis Hartman, diatheke was probably selected in the septuagint because it signified a last will and testament in the popular sense, and a contract or disposition of the will in the more classical usage. This would be used in preference to sundeke, treaty, because in the "Old Testament berith was also used for a unilateral disposition of the will." Thus diatheke means in the

\footnotetext{
${ }^{1}$ Ibid., 110.
} 
Septuagint a bilateral treaty (Gen $21: 27,32$ ), a covenant in the metaphorical sense (Isa 28:18), the covenant between Yahweh and Israel (Exod 24:8; 34:10), or the conditions of the covenant (Pss 103:18; 132:12).1

The New Testament uses diatheke "26 times; 7 times in citing the OT, 16 times in alluding to it, and 3 times independent of the OT." Consequently, the New Testament writers kept to OT concepts and, being Jews, would have a covenant and not a treatment in mind. ${ }^{2}$

The apostle Paul saw the covenant ratified by Christ's blood (1 cor 11:25) bringing freedom, while the old covenant could only make slaves (Gal 4:22-31). The basis for the distinction between the old and new covenants is the granting of the Spirit (2 Cor 3:6; Rom 7:6), which frees from slavery of the flesh (Rom $8: 1-4$ ).

Before Jesus came, a covenant made between two persons included the cutting of a living animal in half from top to bottom and shedding its blood, thus symbolizing the death of the covenant maker's individual rights through the death of the animal. Then the covenant makers passed between the two halves of the animal, symbolizing their union (see Jer 34:18-20). When God made a covenant with Abraham, He walked between the split animals alone while Abraham watched, for God and Abraham were not equals.

\footnotetext{
${ }^{1}$ Ibid.

${ }^{2}$ Ibid.
} 
A covenant is a bond in blood. It involves commitments with life-and-death consequences. At the point of covenantal inauguration, the parties of the covenant are committed to one another by a formalizing process of blood shedding. This blood shedding represents the intensity of the commitment of the covenant. By the covenant, they are bound for life and death. ${ }^{1}$

spiritual joining is based on covenant. The relationship between God and Abraham was cemented by a covenant (Gen 15:9-11, 17-18). The relationship between Jesus and His church is based on a covenant (Luke 22:20). The relationship between a husband and wife is also based on a covenant (Mal 2:14).

In his book, The Marriage Covenant, Dr. Samuele Bacchiocchi observes that the

concept of the covenant stands out in scripture among all the signs and symbols used by God to reveal His saving grace. In His mercy God chose to enter into a solemn covenant of love, not only with individuals such as Abraham, but also with the whole house of Israel. They did not deserve His love which He freely manifested toward them. God's covenant of love, though not always reciprocated, is everlasting, extending from generation to generation. ${ }^{2}$

To help His people understand and accept the unrelenting nature of $\mathrm{His}$ covenant of love, in the old Testament God often used the metaphor of the husband/wife relationship. The obvious reason is that the marriage

\footnotetext{
${ }^{1}$ Ibid., 15.

${ }^{2}$ Bacchiocchi, 31 .
} 
covenant, characterized by love, compassion, and faithfulness, fittingly exemplifies God's covenant relationship with His people. ${ }^{1}$

Therefore, the joining is meant to be permanent and to involve commitment. The point that the author of this project wants to show is the idea of inviolability, unalterability, and therefore absolute validity in a marital covenant love relationship.

\section{The Marriage Covenant}

A covenant commits people to one another. In Jer 31:3 God says, "I have loved you with an everlasting love; Therefore I have continued my faithfulness to you" (RSV). Because God made marriage important to understanding spiritual truths, He joins people together spiritually when they marry. This joining is permanent.

God's covenant of grace with His people is made first by the initiative of His gracious promise and its associated requirement: "I will be your God, you shall be my people," and then by His people's acceptance of His undertaking to be their God in their response of obedient love to Him. The public nature of such promise and response was often declared by the giving of a covenant sign. Covenant theology is thus a theology of personal pronoun: I will . . you shall . . The covenant relationship is the

\footnotetext{
${ }^{1}$ Ibid.
} 
life of faithful response to God's initiative and promise and continuing gift of faithful love. ${ }^{1}$

Indeed, the fundamental biblical description of marriage is given in covenant terms and the interchange of analogies by which human marriage is used to describe God's covenant relationship with His people. The relationship between God and His people, or Christ with His church, which is used to provide a pattern for human marriage, can be traced through both old and New Testaments. ${ }^{2}$

For the sake of clarity, the scriptural passages referring to the marriage covenant relationship are mentioned here. Throughout scripture, God is referred to as the husband of Israel "Not like the covenant which I made with their fathers when I took them by the hand to bring them out of the land of Egypt, my covenant which they broke, though I was their husband, says the Lord" (Jer 31:32, RSV). "And in that day, says the Lord, you will call me, 'my husband,' and no longer will you call me 'my Baal'" (Hos $2: 16$, RSV).

In Eph 5:25-33, Jesus is referred to as the husband and the church as the wife.

The prophet Hosea expounded God's covenant of grace by reference to the human reality of marriage. "Chapters 1

${ }^{1}$ David Atkinson, To Have and To Hold--The Marriage Covenant and the Disciple of Divorce (Grand Rapids, MI: Eerdmans, 1979), 70-71.

${ }^{2}$ Ibid. 
to 3 employ the marriage-relationship to describe the bond between God and Israel and the reaction of the chosen people to this situation in terms of the adultery of the wife."1 Hosea's personal marriage to Gomer, a harlot, and her subsequent departure to her "lovers" (2:5) are used as a picture of Israel's unfaithfulness to God. All Gomer had the right to expect from Hosea--all faithless Israel had the right to expect from God--was the judgment of divorce. But then $(3: 1)$ the second theme of the prophecy is introduced:

And the Lord said to me, "Go again, love a woman who is beloved of a paramour and is an adulteress; even as the Lord loves the people of Israel, though they turn to other gods and love cakes of raisins.'

What is important to observe, however, is that Hosea knew the waywardness of his wife from the very beginning of their marriage, just as God was aware of the infidelity of Israel from the time of the wilderness period. ${ }^{3}$

For Hosea, sinfulness was envisaged in terms of the breaking of a covenant or agreement that needed, by definition, to be honored by both the participants. ${ }^{4}$ The prophet taught that the relationship between Israel and God was characterized by hesed, which for him constituted the essence of the covenant. The term is difficult to render by

${ }^{1}$ Roland Kenneth Harrison, Introduction to the old Testament (Grand Rapids: Eerdmans, 1969), 861.

${ }^{2}$ Atkinson, 72 .

${ }^{3}$ Harrison, 867 .

${ }^{4}$ Ibid. 
means of a single word, and attempts to equate it with "zeal" or "piety" tend to substitute only a part for the whole.' Hesed embodies the concept of true love in the light of some specific relationship, and is marked by a profound emotional and spiritual content. ${ }^{2}$

The quintessence of Hosea's message may be thus: "That despite Israel's unfaithfulness to God, God's steadfast love and mercy remain constant, and a way is found for the relationship to be restored." ${ }^{3}$ No wonder the great German philosopher, Hegel, an ardent student of the philosophy of history, said of the history of Israel: "It is a dark, troublesome enigma to me. I am not able to understand it. It does not fit in with any of our categories. It is a riddle."

Samuele Bacchiocchi remarks:

Through Hosea's marital experiences, God revealed Himself to Israel as a compassionate, forgiving husband: "In that day, says the Lord, you will call me, my husband. . . . And I will betroth you to come to me in righteousness and in justice, in steadfast love, and in mercy. I will betroth you to me in faithfulness; and you shall know the Lord" (Hosea 2:16, 19-20). By revealing Himself as a faithful, compassionate and unrelenting husband, God sets a pattern for the husband/wife relationship. What God does on a larger scale as Israel's husband, a human

\footnotetext{
${ }^{1}$ Ibid.

${ }^{2}$ Ibid.

${ }^{3}$ Atkinson, 73 .

${ }^{4}$ Hegel, quoted in Charles L. Feinberg, The Minor
} Prophets (Chicago: Moody Press, 1980), 25. 
husband is called to do on a smaller scale in his relationship with his wife.

The prophet Jeremiah, likewise, reminded the people that God had entered into a covenant with them and had become their husband: "My covenant.. . they broke, though I was their husband" (Jer 31:32). Even though they had broken the covenant, God remained a faithful husband who would make a new covenant with His people, working to transform their hearts (Jer 33:33). The implication is clear: marriage is a sacred covenant in which the husband and wife must be faithful to their commitment as God is faithful to His promise. ${ }^{2}$

Another clear example of the marriage covenant love is Jer 2:2, "Go and proclaim in the hearing of Jerusalem, thus says the Lord, 'I remember the devotion of your youth, your love as a bride, how you followed me in the wilderness." "

In her youth, Israel had responded to the wooing of God's love. In poetic imagery, God is represented as the Lover and Israel His betrothed. ${ }^{3}$ Israel's unfaithfulness (Jer 2:20f.) is expressed in the language of divorce. Because of Israel's infidelity, Judah was captured by the Babylonians and led into captivity. There in a foreign

${ }^{1}$ Bacchiocchi, 32 .

${ }^{2}$ Ibid.

${ }^{3}$ SDA Bible Commentary (Mountain view, CA: Pacific Press Pub. Assn., n.d.), 4:358. 
land, Ezekiel resounded God's hesed toward Israel. It is one of His central characteristics. God's loving kinaness is offered to His people, who needed redemption from sin, enemies, and troubles. ${ }^{1}$

Ezekiel used the image of "infidelity," the "harlot," the "adulteress" in his vivid descriptions of Jerusalem's marriage with the Lord. In chap. 16, for example, Jerusalem is depicted as God's bride: her birth (16:4), her growth of marriageable age (16:7), their betrothal and marriage (in covenant language, 16:8), and her infidelity and adultery $(16: 15-34)$ are traced out, and God's punishment for unfaithfulness is clear $(16: 40)$. Yet though the marriage covenant was broken (16:59), God did not forget His promise of love $(16: 60 f.) .^{2}$

In a similar vein, Isaiah uses the marriage imagery. God brought Israel out of Egypt to become His bride, but she had become unfaithful by serving other gods (Jer 3:1-11; Ezek 16:8-16; Hos 2:5-12). This was her disgrace and shame. Her ugly past would be forgiven and forgotten, and she would be restored to the privileges and honor originally promised her. Although Israel had forsaken her "husband," He would bring her back to Himself and again be her husband. ${ }^{3}$

Testament, 233 .

${ }^{1}$ Nelson's Expository Dictionary of the old

${ }^{2}$ Atkinson, 73 .

${ }^{3}$ SDA Bible commentary, $4: 294$. 
For the Lord has called you

Like a wife forsaken and grieved in spirit,

Like a wife of youth when she is cast off,

says your God. For a brief moment I forsook you, but with great compassion. I will gather you. In overflowing wrath for a moment I hid my face from you, but with everlasting love I will have compassion on you, says the Lord, your Redeemer (Isa 54:6-8, RSV).

The above citations and examples suffice to show how the old Testament prophets often describe God's covenant relationship with His people in terms of an ever-loving, faithful husband who never tires of wooing back an unfaithful wife." "This example of God as a faithful and loving husband reveals what God intends marriage to be: a sacred covenant where love and faithfulness prevail."2

Malachi is the last of the great succession of prophets who gives a synopsis regarding the indissoluble nature of the marriage covenant. "Malachi's message is, for the most part, rebuke and condemnation. The moral and spiritual conditions of Israel in his day are those of professing christendom today." ${ }^{3}$

The sins of Israel that provoked Nehemiah were the same that stirred up Malachi. The failures were: (1) the defilement of the priesthood; (2) foreign marriages with

\footnotetext{
${ }^{1}$ Bacchiocchi, 33 .

${ }^{2}$ Ibid.

${ }^{3}$ Feinberg, 249 .
} 
divorce of their Israelitish wives; and (3) neglect of the tithe and offerings. ${ }^{1}$

Nowhere in the old Testament do we have so much said concerning the evil of divorce. We need not press its applicability to our own day; it is a sin that cries out mightily unto God. But the contemporaries of the prophet ask why God should reject their sacrifices. The answer is because God was a witness to the legally contracted marriage where God was called to witness the covenant. Their wives were the companions of their youth, their choice in youth sharing both the joys and sorrows of life. ${ }^{2}$

The message in Malachi is crystal clear. God hates divorce, the putting away of wives. "This verse is not at variance with Deut 24:1, where divorce is allowed. This was countenanced because of the hardness of their hearts (see Matt $19: 3-8) .{ }^{3}$ It is not difficult to see, since the prophet is speaking of divorce, a reference here to the original institution of marriage by God Himself.

Notice that "both mixed marriages and divorce were abhorrent to God." The marriage of men of Israel with idolatrous women had another aspect to it. There was a second thing, a second sin. Such marriages involved divorcing their Jewish wives. These forsaken wives came to

\footnotetext{
I'Ibid., 250.

${ }^{2}$ Ibid., 257 .

${ }^{3}$ Ibid. , 258 .
} 
the altar of the Lord and covered it with their tears. Thus when the former husbands came with their offerings, the Lord would not receive them with good will. Because He had regard for the tears from their heartbroken wives, He had no regard for their offerings.' (See Mal 2:11-17.)

Samuele Bacchiocchi observes,

Note that God hates divorce, not the divorcee. As Christians we should reflect Christ's attitude of loving concern toward those who have suffered marital disaster (John $4: 6-25$ ) while at the same time upholding the Biblical imperative of the sacred and inviolable nature of the marriage covenant. ${ }^{2}$

Malachi urges us not to divorce the wife to whom we have promised fidelity, because "the Lord was witness to the covenant between you and the wife of your youth, since she is your companion and your wife by covenant."

"Malachi's teaching on the sacred nature of the marriage covenant was reiterated and expanded four centuries later by Christ Himself." ${ }^{3}$ Jesus referred to marriage many times. (See Matt 19:3-12; Mark 10:2-12.)

To the question asked by the Pharisees, "Is it lawful to divorce one's wife for any cause?" Jesus answered, Have you not read that He who made them from the beginning made them male and female, and said for this reason a man shall leave his father and mother and be joined to his wife, and the two shall become one flesh? so they are no longer two but one flesh. What

\footnotetext{
${ }^{1}$ Harrison, 959.

${ }^{2}$ Bacchiocchi, 34 .

${ }^{3}$ Ibid.
} 
therefore God has joined together, let not man put asunder (Matt 19:3-6, RSV).

It is interesting to note that the first part of what Jesus says is an exact quotation by Jesus from Gen 1:27. Here Jesus affirmed that God is the Creator of humankind, and that from the beginning humankind was created male and female. This shows that human sexuality, sexual functions and activity, and sexual capabilities and needs are God's will for mankind and part of God's gift to mankind, and in fact are an essential element of being human.

After having aroused in the man this awareness of longing and need, God places him in a deep sleep, and from man's side He makes woman. Thus woman is taken from man, showing that each is incomplete without the other. So the story of creation shows, and the teaching of Jesus confirms and reinforces, that a human being is deliberately created by God with the three types of need: for companionship, mutual help, and sexual fulfillment. God plans that we shall be aware of our need, and then shall have the joy and the satisfaction of having it fully met in the relationship of marriage.

Jesus said, "What God has joined together, let not man put asunder" (Mk 8:9). Here there is an emphasis put upon the permanence of the marriage bond. Unequivocally Jesus affirmed that the marriage covenant must not be disrupted by divorce and remarriage because it is a sacred, 
inviolable bond. To do otherwise is to commit adultery. ${ }^{1}$ The biblical teaching of lifelong monogamy stands as the only alternative.

Another advocate of the permanence of marital covenant love is St. Paul. In Eph 5:22-33, Paul compares the union of husband and wife to that of the believer and christ. It is interesting that Paul also quotes Gen 2:24 to emphasize the oneness of husband and wife: "For this reason a man shall leave his father and mother and be joined to his wife and the two shall become one flesh" (Eph 5:31). Calvin's New Testament Commentaries put it this way:

That is, they shall be one man, or, to use a common phrase, they shall constitute one person, which certainly would not hold true with regard to any other relationship. All depends on this that the wife was formed of the flesh and bones of her husband. "2

According to Paul, no man can love himself without loving his wife. Marriage was appointed by God with the purpose that the two should become one person. The husband is supposed to love his wife as exemplified by christ who loved the church and died to save and purify her.

In the Ephesian passage, the analogies are interchanged. Christ and His church are pictured as bridegroom and bride, but the context in which this is set is the exposition of the obligations of human married life,

${ }^{1}$ Ibid., 35.

${ }^{2}$ Calvin's New Testament Commentaries (Grand Rapids: Eerdmans, 1979), 209. 
which is, says Paul, to be patterned on the relationship of Christ with His church. It is of the living bond of committed love between Christ and the church that Paul uses the language of "one flesh."1

The covenant language implicit in the pronouns of Gen 2:24 is thus made explicit in Eph 5:31. The primary purpose of marriage is to be found in the acceptance of God's will that the covenant relationship of man and wife, both made in the image of God, shall be an image of $\mathrm{His}$ covenant relationship with His people. ${ }^{2}$

G. R. Dunstan suggests five marks of comparison between God's covenant with His people and human marriage. The first is an initiative of love inviting a response, and so creating a relationship. Second, as God's covenant of grace is made sure by oath, so the essence of the marriage covenant is the vow of consent, the vow guarding the union against filthiness of the emotional bond, and against the destructiveness of emotional power. Third, covenant conditions are expressed in commandments from God to man. These are paralleled in marriage by covenant obligations of faithfulness.

The fourth mark of God's covenant, continues Dunstan, is the promise of blessing to those who remain

\footnotetext{
${ }^{1}$ Atkinson, 74 .

${ }^{2}$ Ibid., 75.
} 
faithful to their covenant obligations. Here Dunstan explains:

The great word of Genesis that a man shall cleave to his wife and they shall become one flesh, is at once command and promise. It is a command; press on to that unity for the sake of your perfection; see that you fall not out by the way; do not forsake the covenant yourself; and if the other does, remember God in Christ, faithful to His bride the church, and so forgive to the uttermost. This is the command of God. And the promise is that this, the impossible, is possible.

The two do become one, and signify or exemplify to the world the mystical union between christ and his church. What God commands He also gives.

The fifth mark of covenant is sacrifice. In both testaments, the covenant of God with His people is secured by the laying down of life in death. "In marriage, too, there is death: death to the dependence of childhood . . . death to self as a whole, in order to rise to a wholeness of a new sort with the spouse." 2

Samuele Bacchiocchi affirms,

Just as the prophets in the old Testament used the marriage covenant to portray the relationship between God and Israel, so Paul in the New Testament uses the marriage union to represent Christ's covenant of sacrificial love and oneness with the church. Just as marriage unites two people when they commit their lives to each other, so the Gospel joins the believer to christ as he trusts Him for his salvation. Since the marriage covenant relationship represents the permanent relationship between Christ and His church, it must be permanent, otherwise it would be an inaccurate

245 .

${ }^{1}$ G. R. Dunstan, Theology 78, no. 659 (May 1975):

${ }^{2}$ Ibid. 
representation of the indissoluble relationship between * christ and His Church. ${ }^{1}$

${ }^{1}$ Bacchiocchi, 36. 
CHAPTER 2

COVENANT LOVE AND INTIMACY

The following appeared in the Journal of Marital and Family Therapy:

The marital couple that most recently consulted with us complained of a problem that we have encountered again and again in our practice of marital and family therapy. The husband and wife agreed, in despair, exasperation, and seeming self-contradiction: "We no longer have anything in common. We can't agree on anything. We think we still love each other, but we have lost all intimacy.

Edward, 47, and Helen, 43, had lawyers draw up divorce papers. ${ }^{1}$ Compared to others, this couple was unusually articulate in expressing what they meant by "no intimacy." Edward lamented: "I am living in a house of strangers. We never sit down for dinner together. We all do our own thing. I need to communicate--I want to know what she is feeling." Helen confirmed their disconnected lifestyle, but her goal for marriage called for a different version. "I would like him to accept me for what I

\footnotetext{
${ }^{1}$ Lyman C. Wynne and Adele R. Wynne, "The Quest for
} Intimacy," Journal of Marital and Family Therapy 12 (October 1986): 383 . 
am . . , but he talks constantly. He is always wanting to know what I am thinking."1

Marriage is a curious mixture of feelings, romance, reason, and, above all, everyday living. Those who think that love suffices to make a successful marriage are in error. I asked a lady in her early thirties why she had divorced her husband. Was it because she had ceased to love him? "No," she replied, "I still love him, but we could not get along."

Margaret Trudeau, the former wife of Pierre Trudeau, said in an interview with sue Montgomery that she loved and still loves her ex-husband. "I loved him and will always love him. He's the most marvelous man I know. I would do anything for him. It is just sad that it could not work between us as husband and wife." Blaming the break-up on the strains of political life, she added: "What a lucky girl I was to have met him."2 In spite of Margaret's love for Trudeau, she left him in 1977.

The following story is worth repeating. Rosalie married Thomas (a journalist) a few years ago. There was love and intimacy between them. They kept no secrets from

\section{${ }^{1}$ Ibid.}

${ }^{2}$ The Ottawa Citizen, May 15, 1994, A4. Pierre E. Trudeau became Prime Minister of Canada as head of the Liberal Party in 1968 and governed until 1979 when the Conservatives took power. He was re-elected in 1980 and retired in 1984. Margaret married Trudeau in 1971. They separated in 1977 and were divorced in 1983. 
each other. There was openness, dialogue, trust, romance, etc. Rosalie said, "I played the role of a dutiful wife to Thomas. Then he was promoted, and away we went." While Thomas departed each day for the camaraderie and constant commotion of the newsroom, Rosalie cleaned house and cared for their one-year-old son. over the next few years, as Thomas was praised for his work and given added responsibility, Rosalie saw her own skills growing rusty with disuse. Rosalie is an efficient secretary and an excellent writer. Her growing envy of Thomas was mixed with feelings of failure.

Unfortunately, Thomas was too absorbed in his own accomplishments and goals to see the effects of the changes on his wife. He blindly followed the pattern he had witnessed in his parents' traditional marriage--the man at the office and the woman at home. His social life revolved around male team sports--volleyball in summer, hockey in winter.

Listen to Rosalie's own words:

My husband thought I had an easy life. He couldn't understand what the fuss was about. I could not make him see that the big home, the nice car, the beautiful furniture, even the beautiful son could not fill the void in my heart. I wanted to be with him more often. I wanted him to touch me, to caress me and to tell me that he understood my loneliness and he would see to it that after work he would come home instead of spending half of the evening with friends.

What made it even more difficult for Rosalie was that she felt unable to talk to anyone about her 
frustration. When her parents called, she would say that everything was just perfect. She did not want the pastor to visit her, either. She had lost touch with her former classmates, most of whom were either pursuing a career or raising a family. At the end of six years, as Thomas's absences became more and more frequent, she decided, "I cannot take it any longer. Enough is enough."

I asked Rosalie one day, "Have you stopped loving Thomas? Would you say that the reason for divorcing him was a lack of love and intimacy?" She replied, "Pastor, a marriage cannot function without intimacy. I still love him, but he cannot be any longer a part of my life. There was a time when we used to demonstrate love, we used to have romance."

\section{Part one: The Meaning of Intimacy}

Judith $\mathrm{K}$. Balswick defines intimacy

as the process of coming to know and be known by another in a deep, caring way. It involves selfdisclosure and the ability to be naked and not ashamed in emotional, physical and psychological interactions. It entails an openness and shared vulnerability between spouses, which are dependent upon security established in a committed relationship. ${ }^{1}$

Balswick continues:

The bride and groom desire to know and be known in the most intimate ways, including sexual

'Judith K. Balswick, Toward A Practical Theology of Marital Sexuality (n.p.), 285 . 
familiarity. They are pledged to grow together in an I-Thou encounter of personal disclosure and vulnerability in their marital union. ${ }^{1}$

According to Anderson, "Intimacy is discovered when both persons are vulnerable and secure, when each can be defenseless in the presence of the other."2

As human beings, we need closeness and we need autonomy. Closeness implies connectedness and relatedness to another person. Autonomy implies individuality and independence from another human being. ${ }^{3}$

"The principle of intimacy is to know and be known." ${ }^{4}$ God knows us intimately! God sees the sparrow fall, counts the number of hairs on our heads, knows us in all our ways. David wrote: "O Lord, you have searched me and you know me. You know when I sit down and when I rise. You discern my going out and my lying down; you are familiar with all my ways" (Pss 139:1-3).

This is why the Psalmist can cry out in agony as well as in ecstacy to God, who knows the innermost parts of his being. Adam and Eve stood before God completely open and transparent before the Fall. They were naked before each other, without shame, free to be themselves without

\section{${ }^{1}$ Ibid. \\ ${ }^{2}$ Ibid.}

${ }^{3}$ DeLoss D. Friedsen and Ruby M. Friedsen, Counseling and Marriage, vol. 19 (Dallas: Word Publishing, 1989), 178. ${ }^{4}$ Balswick, 292 . 
pretense or deception. Their relationship with God was gravely disrupted when they disobeyed. They hid from God. Their nakedness and shame interrupted their intimacy with God. Fear leads people to put on masks and play deceptive games to keep from being known.1

The capacity of spouses to communicate feelings with each other freely and openly is contingent upon the absence of fear. John gives us insight when he proclaims, "God is love. . there is no fear in love, but perfect love casts out fear" ( 1 John $4: 16-18$ ).

Safety and security in being known comes out of the trust established between spouses in an unconditional covenant love. Covenant love is based on the grace principle (acceptance and forgiveness) and leads to the empowering principle, the mutual giving and receiving that leads to intimacy. ${ }^{2}$

A satisfying, intimate relationship is a precious thing. Watchfulness or alertness is worth the time and effort that we put into it.

\section{Part Two: The Intimacy Principle}

The Seventh-Day Adventist Minister's Manual states: God made both man and women in such a way that neither is complete without the other. The

\footnotetext{
'Balswick, 293.

${ }^{2}$ Ibid., 295.
} 
Creator made Eve from Adam's rib to teach at least three lessons: (1) It was taken from his side, for the woman was neither above nor beneath, but to stand by the side of the man; (2) The rib was from under his arm, for she was to be protected by him; (3) It was taken from near his heart, for she was to be loved by him. Thus it was that Jesus quoted: "For this reason a man shall leave his father and mother and be joined to his wife, and the two shall become one flesh" (Matthew $19: 5) .1$

Robert C. Kistler states in his book, Marriage, Divorce, and....:

Holy wedlock. It is more than two people trying to live, in a time of economic stress, more cheaply than one. It is more than having a legal sexual partner. It is a total relationship sanctioned by God. Reference is usually made to marriage coming to man with the sweet fragance of Eden and to Christ's presence at the marriage feast in Cana of Galilee. ${ }^{2}$

The couple may be reminded, Kistler adds, that marriage is "a lifelong union," "A Holy covenant," and that from henceforth, the other person in marriage is the most important person for husband or wife." "Therefore shall a man leave his father and his mother, and shall cleave to his wife, and they shall be one flesh" (Gen 2:24). Adam and Eve knew that they belonged to each other and that their marriage was indeed a lifelong union, a holy covenant.

${ }^{1}$ Seventh-Day Adventist Minister's Manual (Silver Spring, MD: General Conference of Seventh-day Adventists, $1992), 256$.

${ }^{2}$ Robert C. Kistler, Marriage, Divorce, and...', ed Raymond H. Woolsey (Washington, D.C.: Review and Herald Publishing Association, 1987), 16.

${ }^{3}$ Ibid. 
4. And they were both naked and were not ashamed-Intimacy. ${ }^{1}$

Intimacy cannot truly exist without the presence of these three "musts": severance, permanence, and unity. These three are now briefly considered in turn.

\section{Severance}

Leaving father and mother has great psychological importance. Early in our psychological development, usually in the first four years of life, we go through a process of separation and individuality to become distinct and unique individuals. "We are separate, and yet we are not abandoned. We learned we could switch from being alone to being together and back to being alone. We had true closeness and we had true autonomy." 2 The command to "leave and to unite" appears in the Bible before the command to "honor and obey" one's parents. A person must know that he or she is the most important person to his or her spouse. While one still loves one's parents, one's spouse must occupy first place in one's life. ${ }^{3}$

${ }^{1}$ Charles Swindoll, Strike the original Match: Rekindling and Preserving Your Marriage Fire (Portland, OR: Multnomah Press, n.d.), 21. 132 .

${ }^{2}$ Friedsen and Friedsen, Counseling and Marriage,

${ }^{3}$ Ibid., 133 . 
Permanence

God intends marriage to be permanent. His will for every spouse is emotional, physical, and financial security. Paul tells us: "To the married, I give this command (not I, but the Lord). A wife must not separate from her husband, but if she does, she must remain unmarried or else be reconciled to her husband, and a husband must not divorce his wife" (1 Cor $7: 10,11)$.

The Lord Jesus Christ and the Apostles took pains to emphasize its importance and its permanence and to give careful instructions, concerning married life. The highest and holiest glorification of marriage came when the inspired Apostle Paul used it as a figure of the relationship of Christ with His Church. 1

I referred earlier to the intimacy or closeness of the relationship between God and marriage partners. One may also rightly say that marriage involves a solemn covenant between God and the couple. Marriage is certainly something beyond a mere physical union. It is a union of two personalities; a meeting of souls. Each retains his or her separate individuality, but in a very real sense the two become one, and this by their own voluntary choice. ${ }^{2}$

commitment is an aspect of permanence. Commitment is one of the factors that causes the marriage to endure. When things are going smoothly or when the couple is deeply

${ }^{1}$ Robert G. Rayburn, o come, Let US Worship (Grand Rapids, MI: Baker Book House, 1980), 273.

${ }^{2}$ Ibid. 
in love, commitment is not needed to keep the couple together. It is when things are rocky or when the first love grows weak that commitment needs to come into play. commitment is the glue that holds the couple together during those times when the marriage has little going for it. ${ }^{1}$

Unity

In a healthy marriage, to be united means to share a common commitment, a common purpose, and common goals. It means agreement on the central issues. Unity requires giving up some of myself for the sake of the relationship. I put my spouse ahead of my parents, my friends, my activities, and my children. My spouse does likewise. This is unity. ${ }^{2}$

In order to maintain unity in our relationship, we must often sacrifice what we are. I should spend time with other loved ones and even leave time for myself, but not to the detriment of my marital relationship. My spouse should do likewise. ${ }^{3}$

133.

${ }^{1}$ Friedsen and Friedsen, Counseling and Marriage,

${ }^{2}$ Ibid.

${ }^{3}$ Ibia. 
Part Three: Building and Maintaining Intimacy

In his book Maximum Achievement, Brian Tracy states:

You get out of your marriage or romance exactly what you put into it. The more of yourself that you put into a relationship, the more love, satisfaction and joy you will get out of it. Men and women are born incomplete, and need each other to become whole. They are born with complementary qualities and characteristics. Each needs the other to fulfil his or her human destiny. Happy relationships go hand in hand with peace of mind, long life, health, happiness and abundance. Men and women with poor relationships, or no relationship at all, have more ill health and die younger than men and women who live happily together. ${ }^{1}$

Tracy provided evidence to show that divorced men die from heart disease, cancer, and strokes at double the rate of married men. The rate of all types of cancer is five times higher for divorced men and women, compared to their single counterparts. If for no other reason than your desire to live a long and happy life, you should be very serious about building and maintaining excellent relationships with the most important person in your life. ${ }^{2}$

one's ability to create love and intimacy is directly proportional to one's skill and willingness to deal effectively with conflict and anger. It is easy to love and feel close when things are going well, but your mutual

\footnotetext{
${ }^{1}$ Brian Tracy, Maximum Achievment (New York: Simon and Schuster, 1993), 286.

${ }^{2}$ Ibid., 286.
} 
respect and goodwill is tested in times of antagonism or disappointment. ${ }^{1}$

The ability and willingness to resolve conflicts successfully are among the most important social skills you can possess. These skills alone will help you gain selfconfidence and the respect of people around you. ${ }^{2}$

Strategies for resolving conflicts may be classified into nine basic types: (1) flight, (2) diversion, fighting, (4) compromise, (5) "smooth," (6) withdrawal, confrontation, (8) seeking help, (9) constructiveness.

\section{Flight}

Some people seem to take off at the first sign of conflict. One lady told me, "My marriage was a mistake, anyway. There is no need to try. We were not meant for each other."

Some couples flee into silence. Another person alleges, "My husband won't discuss anything." There are situations where flight is the most appropriate and effective strategy. If your partner cannot control himself or herself in public, or seeks to embarrass you in the company of friends, the best thing to do is to remain silent or to leave the location.

${ }^{1}$ Judith A. Sellner and James G. Sellner, Loving for Life (North Vancouver: Self-Counsel Press, 1991), 102.

${ }^{2}$ Ibid. 


\section{Diversion}

Diversion is an attempt to delay undesirable action by deflecting attention away from the conflict. Changing the subject and criticizing your partner's mode of expression are tactics designed to divert attention away from the real problems or to keep the issue so unclear that attempts at a constructive resolution of the conflict are impossible.

A biblical example of diversion is found in Dan 2. King Nebuchadnezzar had dreams and was unable to remember what he saw in the dreams. The king summoned the wise men to his kingdom to tell him the dreams. The wise men tried to divert the king's attention. The king responded by saying, "I know for certain that you are bargaining for time - . for you have agreed together to speak lying and corrupt words before me until the situation is changed" (vss. $2,8,9$ ).

By contrast, the prophet Daniel did not try to divert the king's attention. Rather, he candidly asked for more time in order to come up with a satisfactory answer.

\section{Fighting}

When in doubt, attack. This is the strategy adopted by some people in the face of conflict. The intention is to get power over the other by the use of physical force (a punch in the nose); verbal abuse (screaming, yelling, accusing, trying to make the other person feel guilty); or 
punishment, both overt and covert (witholding love, sex, money, anger, anxiety, alienation, and physical assault are the usual by-product of fighting). ${ }^{1}$

\section{Compromise}

Compromise means avoiding zero-sum games or the "I win, you lose" approach. There is some give and take. The couple meets each other in the middle.

\section{$\underline{\text { Smooth }}$}

Smooth means to relinquish to the other person. Decide who needs it more. Let that person have it.

\section{Withdrawal}

Withdrawal means the turning inward of one partner, refusing to communicate on an issue.

\section{Confrontation}

This means to face the conflict, to negotiate, to think of situations that give both parties what they want and keep the relationship positive.

\section{Seeking Help}

Some couples consult a good counselor. They may go to a mediator. Or they may consult their pastor, etc.

\footnotetext{
${ }^{1}$ Sellner and Sellner, Loving For Life, 104.
} 


\section{Constructiveness}

Constructiveness requires that you learn and practice a set of skills:

a. The ability to figure out the source of the conflict

b. An ability and willingness to initiate constructive action as in the case of Tom and Barbara, mentioned earlier

c. The ability to use the process of conversation (see chapter 2)

d. The discipline to engage in a problem-solving process to bring about mutually acceptable action. ${ }^{1}$ When one faces a conflict one needs to ask oneself the following questions:

1. What do I gain from continuing the conflict?

2. What does my partner gain from continuing the conflict?

3. Does the conflict help me to mature?

4. Does this conflict help my partner to grow up?

\section{Part Four: The Marital Pyramid}

The Marital Pyramid illustrates well the steps to intimacy in a covenant love relationship.

IIbid., 105. 
Intimacy

Conflict Resolution \& Management Communication skills

Spiritual, Emotional \& Mental Health of Partner

The Marital Pyramid has four layers. The bottom or foundation layer is the spiritual/emotional/mental health of the partner. This has a great bearing on the happiness of the marriage. No one has perfect emotional responses and attitudes. However, it is important to a successful marriage for both partners to be free of any major spiritual, mental, and emotional problems.'

Couples should be careful to get enough rest, to maintain a healthy diet, to exercise regularly, to worship the creator, and to find time to pray. Let me make it clear: Unless the life of the couple is undergirded by an outside power--I call it the power of God or the power of the Holy spirit--these techniques may not be of much use. Jesus Christ said it well, "Apart from me, you can do nothing" (John 15:5).

The second layer of the pyramid is communication skills. Communication techniques are provided in chapter 3. True intimacy cannot exist without effective communication.

\footnotetext{
${ }^{1}$ Adapted from Friedsen and Friedsen, Counselling and Marriage, 19:56.
} 
The third layer is conflict management. Learning to * solve problems is a sign of growth. The way one handles life's vicissitudes, in particular the way one handles marital conflict, shows what type of person one really is. Intimacy is at the top of the pyramid. It is also the hallmark of a good marriage. Trying to help couples achieve intimacy while there are major unresolved conflicts is unlikely to be effective. This does not mean that the marriage has to be conflict-free. However, when conflict arises, the couple's closeness must be able to help them deal with it constructively.

D. and M. Friedsen state that

any major psychiatric disorder--depression, anxiety, phobia, manic-depression, illness, schizophrenia, or paranoia, and any significant personality disorder--asocial, avoidant, antisocial, passive-aggressive--can contaminate the higher levels of the pyramid.

According to Dr. Allen B. Weisse, the different types of personality disorders are readily recognizable. ${ }^{2}$ Dr. Weisse's descriptions of personality disorders follow. The paranoid personality is characterized by longstanding suspicion and mistrust of others. 56,57 .

${ }^{1}$ Friedsen and Friedsen, Counseling and Marriage,

${ }^{2}$ Allen B. Weisse, The Man's Guide to Good Health (Yonkers, NY: Consumer Report Books, 1991), 162, 163. Dr. Weisse is a practicing cardiologist and a professor of Medicine at New Jersey Medical School in Newark. 
The schizoid personality is isolated and lonely, and uncomfortable with human contact.

Histrionic types are excitable, emotional, and flamboyant, but often superficial in their relationships. Antisocial subjects are unable to conform to the norms of society and are often found among the criminal class.

Narcissistic personalities tend to focus on their own physical and personal attributes and problems to the exclusion of others.

Avoidant personalities are unable to interact with others for fear of rejection and are commonly labeled as having "inferiority complexes."

The dependent personality is a submissive individual who often burdens others with his personal indecision and is in constant need of approval and reassurance from others.

The compulsive person is characterized by his or her inflexibility and perfectionism as well as indecisiveness.

The passive-aggressive person is driven by an underlying aggression masked by subtle obstructionism, inefficiency, and resistance to change.

The sadistic personality delights in hurting others. The masochistic individual enjoys being hurt or abused.

Individuals with personality disorders think of themselves as perfectly normal and rarely seek help for 
their problems. As a result, their patterns of behavior, well established by adolescence, usually persist throughout adulthood. For instance, the neurotic patient frequently continues to function in society--going on with his or her daily work and household tasks despite any distress caused by mental or emotional symptoms. ${ }^{1}$

The psychiatric disorders mentioned above, when manifested in a relationship, can, if they are brushed aside, undermine love and intimacy. Like athletes, couples must keep themselves in a state of physical and mental health if they want to experience optimum levels of marital satisfaction. However, in the final analysis, we sustain intimacy by choosing to give. Paul wrote to the Corinthians:

The husband should fulfil his marital duty to his wife, and likewise the wife to her husband. The wife's body does not belong to her alone, but also to her husband. In the same way, the husband's body does not belong to him alone, but also to his wife. Don't deprive each other except by mutual consent and for a time, so that you may devote yourselves to prayer. Then come together again so that Satan will not tempt you because of your lack of self-control ( 1 Cor 7: 3-5).

Married couples have the responsibility to care for each other. Therefore christian couples should have a high regard for their sex lives. A husband must understand that a wife desperately needs tenderness, understanding, and love. To be able to give herself freely to him, she needs

'Ibid., 157. 
to talk about unresolved conflicts and have them solved before making love.'

Building and maintaining intimacy constitutes one of the best ways to create excitement in the covenant marital love relationship. DeLoss D. Friedsen points out: "The thoughts, the feelings, and the behaviors of people in intimate relationships are positive. Positive about the marriage, positive about their partners, and positive about themselves. "2

Love and intimacy cannot be separated. They may not be equated, but they certainly go together. When partners are intimate, they are emotionally and physically close in a way that allows them to feel safe while being vulnerable.

\section{Stages of Intimacy}

One of the keys to building and maintaining a sucessful marital covenant love relationship lies in understanding that intimacy goes through four stages. They are: the romantic/honeymoon stage, the conflict/power struggle-stage, the interdependence stage, and the full commitment stage.

${ }^{1} \mathrm{Jack}$ Mayhall and Carole Mayhall, Marriage Takes More Than Love (Colorado Springs: Navpress, 1978), 218. 126.

${ }^{2}$ Friedsen and Friedsen, Counseling and Marriage, 
The romantic/honeymoon stage

This is the wonderful initial stage of togetherness and oneness that most couples go through. In its pure form, the man and woman want to spend all their time together and seem to have similar tastes, feelings, and desires. In this stage they perceive each other as being incredibly alike. In this stage, the need for closeness is met, and there is no fear of abandonment. ${ }^{1}$

This stage is wonderful; it is exciting. There is a strong feeling that you were made for each other or that you have found something that draws you together. This romantic/honeymoon stage is healthy and important. "However, there is something potentially destructive about this stage if it continues too long. After a while, comes the fear of being swallowed up by the other person."2

The conflict/power struggle stage

This stage can also be called the separation and individuation stage. In this stage, the two persons emphasize individual identities. They no longer see everything alike. In fact, they may begin to emphasize their differences in taste, values, activities, parenting styles, and even religious convictions.

\footnotetext{
${ }^{1}$ Ibid.

${ }^{2}$ Ibid.
} 
The conflict/power-struggle stage begins when you realize that your partner is not all he or she appeared to be. He does something you do not like. She disappoints or betrays you. You realize that some of your basic values run counter to his or hers. Your likes and dislikes begin to clash. ${ }^{1}$

Anger, silence, jealousy, yelling at one another, slamming doors, withholding sex, demanding sex, being "nice," feeling tired as soon as he walks in the door, and fighting over money are some of the symptoms of the powerstruggle stage. ${ }^{2}$

In this stage, each sees the negative aspects of the other partner that strike at the other's core. The honeymoon or romantic stage has faded. Power struggles arise when the husband tries to tell his wife how she "should" be, but is not, and she does the same to him.

In this stage, each person pulls away from the other (separation) and each one emphasizes his or her individual identity (individualization). Doctors Judith A. and James G. Sellner remark:

This stage of relationship is inevitable and unavoidable. It's the stage at which couples separate, divorce, berate each other verbally or physically, and enter counseling. The problem is not that conflicts and power struggles occur in relationships; the problem is that we are not taught how to deal with them and move beyond them.

\footnotetext{
${ }^{1}$ Sellner and sellner, 22.

${ }^{2}$ Ibid.
} 
Indeed, long-term love and intimacy is built on a foundation of resolved conflicts and power struggles. Lasting love and deep happiness must be earned. The major difference between a relationship that is chronically and destructively in conflict and one in which love, intimacy, respect and companionship grow is each person's willingness to learn the required knowledge, attitude, skills, and behavior. ${ }^{1}$

one of the indispensable skills for resolving conflict is active listening. Active listening means listening acutely and understanding what the other is really saying.

The interdependence stage

"Interdependence means each person can live and function independently of the other. The interdependence stage is the midpoint between the extremes of total togetherness and dependence or total separation and independence. "2

This stage can also be called the realistic stage. To choose reality is to allow yourself to see the good, the bad, the ugly, and the beautiful sides of your partner. Out of this comes a feeling of safety based on knowing who your partner is. You are with a real person and each person has his/her strengths and weaknesses. You know that your partner can be sometimes "beast," sometimes "angel."

\footnotetext{
${ }^{1}$ Ibid., 24 .

${ }^{2}$ Friedsen and Friedsen, 130.
} 
Problems may be due to the pressures of earning a living, raising a family, or serving the needs of the church and the community, and from the investment of time in other activities. However, problems can also arise because couples are not taught that there can be intimacy (or closeness), togetherness, and interdependence at the same time.

The full commitment stage

A truly loving relationship requires commitment. Marriage is a covenant. It is indissoluble. clinical philosopher Dr. Peter Koestenbaum calls it "the decision to care." All relationships go through trying times--economic or psychological crises, illness, deep disappointments, or betrayals. That is the nature of ethical love, what has been referred to as covenant love. It is the result of a promise made and kept. ${ }^{1}$

Through commitment, you can create a true partnership expressed in such statements as "I want to be with you." It is what we call being yourself in relationship. It means that you are going to work out with each other the essentially conflicting goals of freedom and intimacy, of separateness and unity, of loneliness and sharing. In doing so, you make a commitment to keep your

\footnotetext{
'Sellner and Sellner, 31.
} 
relationship loving, fresh, alive, interesting, and authentic. ${ }^{1}$

The people in our lives might be divided into three groups. Acquaintances are people whom we know only casually. Friends are closer. They are people who care for one another, spend time together, and have similar interests and viewpoints. Intimates have all the characteristics of friends, but they also share mutual concerns and personal struggles. ${ }^{2}$

In marriage, intimacy includes sexuality. Husband and wife should show understanding and experience a closeness, acceptance, loyalty, vulnerability, accountability, caring, empathy, and love that is not present in mere friendship.

Physical communication is the most intimate expression of a highly successful marriage. For too long, principles and information concerning the sexual relationship have been presented outside of God's truth. The implication often is that God and sex are set against each other. On the contrary, God is for sex! ${ }^{3}$

${ }^{1}$ Ibid.

${ }^{2}$ Gary R. Collins, Christian counselling: A Comprehensive Guide (Dallas: Word Publishing, 1988), 189.

${ }^{3}$ Tim Timmones, Maximum Marriage (New Jersey: Fleming H. Revell Company, 1976), 19. 


\section{Part Five: Intimacy Brings Satisfaction}

Lucy and william Hume in their book, practicing Marriage, point out that "practicing marriage is a practice in intimate living." Intimacy, closeness with another, brings deep satisfaction to the human spirit. Intimacy eases the anxiety of our estrangement and loneliness. We feel joined to another, and it feels warm and good. We have found our "fit" and feel complete. The creator said, "It is not good that the man should be alone" (Gen 2:24).1

Intimacy is obviously something for which we were made. Being created in God's image means being created for communion with God. This union is what distinguishes our humanity and completes it. ${ }^{2}$ The story of the Fall follows the institution of marriage. The Fall is a fall away from the divine image--from communion into isolation, alienation, and loneliness. The Creator's act of redeeming fallen humanity restores it to communion, to intimacy. All the barriers to closeness are removed through the divine initiative of forgiveness. ${ }^{3}$ (See chapter 3.) This forgiveness is received in the initiatory sacrament of

${ }^{1}$ Lucy Hulme and William Hulme, Practicing Marriage (Philadelphia: Fortress Press, 1987), 23.

\footnotetext{
${ }^{2}$ Ibid.

${ }^{3}$ Ibid.
} 
baptism in which we are covenanted--bonded to God--in a union that is comparable to marriage.

Intimacy is also a union of minds. Marital partners are soulmates. Analogous to our communion with God, "one flesh" signifies a union of body and mind and spirit, with sexual intercourse as its most holistic expression. "Sexual oneness is one of the unique features of marriage; but it is not the only unique aspect."1

Men and women need companionship. Alhough they are in communion with God, companionship with the Divine does not obviate the need for companionship with humanity. ${ }^{2}$

The Church is the bride of Christ. (See Rev 21: 9.) It is also the body of christ. The interrelationship among the members of this body provides the social complement to the inner dialogue of the individual with Christ. Marital companions can be supported in their relationship by friendships with fellow members of the body of christ.

${ }^{1}$ Charles M. Sell, Achieving the Impossible: Intimate Marriage (Portland, OR: Multnomah Press, 1978), 35.

'Ibid., 36. 
CHAPTER 3

\section{COVENANT COMMUNICATION}

Communication is as vital to the "good health" of the relationship as good circulation of the blood is to the body's health. Blood brings nourishment and oxygen and carries away poisons and wastes. If circulation is impaired, the body sickens and may die. Communication brings new ideas and signs of caring and acceptance, and it carries away fears and anxieties. If dialogue is impaired, the relationship weakens and may die.'

Not only does communication facilitate the relationship in good times, it is also crucial in helping to mend a fractured marriage. In fact, what and how we communicate influences, more than almost anything else, the process of conflict resolution.

Bornstein and Bornstein report that as many as 90 percent of all distressed couples cite communication difficulties as a major problem in their relationships. Communication may not be the most important area with a

'John L. Thomas, Beginning Your Marriage (Chicago: ACTA Publications, 1987), 73 . 
specific couple, but it is often the most obvious symptom of a relationship gone sour. ${ }^{1}$

If couples want their love to grow, they must communicate openly and honestly. Couples should try to understand each other. They can learn to manage their feelings in accordance with the fundamental values of respect, mutual understanding, and tenderness in order to create happier, more fulfilling marital lives. The Golden Rule, "Do unto others as you would have them do unto you," should be the motto of couples desiring to improve their relationships.

How can communication in the marital covenant love relationship be compassionate, non-judgmental, and psychotherapeutic? What is effective and ineffective communication in covenant relationships? We shall analyze here the main hindrances to good communication in the covenant love relationship and provide couples with skills to avoid them.

It is through communication that husbands, wives, and other family members interact. Effective communication is a sine qua non for every aspect of marital functioning. Communication in marital covenant love relationship is much more than just the exchange of words. All behavior conveys some message and is, therefore, a form of communication.

\footnotetext{
${ }^{1}$ Friesen and Friesen, 125.
} 
We communicate with our partners through words, actions, and attitudes, and by other means. All communication involves persons transmitting symbols to which certain meanings are attached. ${ }^{1}$

\section{Part one: The Importance of covenant communication}

J. A. Fritze, a Lutheran minister and clinical counselor, has said:

You can't know anyone unless you communicate with them. You cannot love anything you don't know. Therefore, the depth of love existing between husband and wife will largely depend on the amount and depth of their communication.?

Communication (verbal and non-verbal) is a process of sharing information with another person in such a way that he or she understands what you are saying. ${ }^{3}$ Communication experts tell us that there are six messages involved in the communication process:

1. What you mean to say

2. What you actually say

3. What the other person hears

4. What the other person thinks he hears

'Leo Buscaglia, Loving Each other: The Challenge of Human Relationships (New Jersey: Slcak, 1984), 53.

'J. A. Fritze, quoted in Mayhall and Mayhall, 65.

${ }^{3}$ Ibid. , 66. 
5. What the other person says about what you said

6. What you think the other person said about what you said. ${ }^{1}$

The basic, most important techniques that couples must possess to deal effectively with interpersonal problems are communication skills. Both partners must be willing and able to communicate. Regardless of how willing and skillful one's partner might be, the communication quality is impaired unless the other partner somehow matches this willingness and skill. ${ }^{2}$

Both partners must desire deep, personal communication in their marriage. They have to make this a mutual priority. If one partner desires intimate communication and the other is indifferent, there is the likelihood of an impasse. ${ }^{3}$ However, a kind, patient, understanding, empathetic, communicative partner can be an excellent teacher. Where there is a will, there is a way.

${ }^{1}$ Mayhall and Mayhall, 67.

${ }^{2}$ Challon O'Hearn Roberts and william P. Roberts, Partners in Intimacy: Living Christian Marriage Today (New York: Pantist Press, 1988), 33 .

${ }^{3}$ Ibid. 
Part Two: Effective Communication

The first aspect of effective communicaton is the sending of a message. The three basic requirements for sending an effective message are to phrase the message so it may be understood, have credibility as a sender, and encourage feedback on how the message is affecting the receiver. ${ }^{1}$

How can couples know when communication is working effectively and when it is not? Effective communication exists between persons when the receiver interprets the sender's message in the same way the sender intended it. If John tries to communicate to Jane that it is a wonderful day and he is feeling great by saying, "Hi," with a warm smile, and if Jane interprets John's "Hi" as meaning John thinks it is a beautiful day and he is feeling well, then effective communication has taken place. ${ }^{2}$

Poor communication in the relationship undermines family functioning. This can happen in a number of ways. For example, communication involves one person expressing something while another person listens. So, good communication in a covenant love relationship involves

${ }^{1}$ David W. Johnson and Frank P. Johnson, Joining Together: Group Theory and Group Skills (Englewood Cliffs, NJ: Prentice-Hall, 1991), 161.

İid., 107. 
partners who are good not only at expressing thoughts and feelings, but also at listening to each other.

Challon O'Hearn Roberts and William P. Roberts, in their book, Partners in Intimacy: Living Christian Marriage Today, declare: "If asked what is the most important thing a couple must do to work toward marital intimacy, the answer would have to be: Communicate! Communicate! Communicate!"1 strong families and happily married couples have been found to practice good communication. They are good listeners, and they are skilled in expressing their thoughts, desires, and emotions to one another. ${ }^{2}$ Dr. Judson Swihart remarks:

strong families do not automatically have a good communication system. They have to desire it, work at it, re-evaluate it. Communication requires a constant watchful eye and large doses of nurturing. ${ }^{3}$

David and Vera Mace in their book, The Sacred Fire, state, "An effectively functioning communication system is first and foremost in a marital love relationship." 4

${ }^{1}$ Roberts and Roberts, 30 .

${ }^{2}$ George A. Rekers, counseling Families (Waco, TX: Word Books, 1988), 107.

${ }^{3}$ Ibid.

${ }^{4}$ David Mace and Vera Mace, The Sacred Fire: Christian Marriage Through The Years (Nashville: Abingdon Press, 1987), 253. 
The authors add that couples can be trained in communication skills, and that such training can "bring real vitality to a languishing marriage."1

\section{Part Three: Characteristics of Good Communication}

Dr. Ketterman ${ }^{2}$ has identified seven characteristics of good communication:

1. Communicators must have open minds and must focus on the present. ${ }^{3}$

2. Communicators make sure their intellects are not subservient to their emotions.

3. Communicators must resist the temptation to be judgmental or to condemn.

4. Communicators must learn to empathize with each other, while avoiding execessive sympathy or pity.

5. Communicators do best when they "listen with their hearts as well as their heads."

I'Ibid., 253.

${ }^{2}$ See Rekers, 107.

${ }^{3} \mathrm{Dr}$. Samuele Bacchiocchi, The Marriage covenant, 112, echoes the same idea. Dr. Bacchiocchi recounts the story of a woman who complained to her friend that her husband became historical every time they had an argument. "Her friend corrected her by saying, 'You mean he becomes hysterical.' 'No,' replied the woman, 'I mean historical. Whenever we have an argument, he brings up every related problem since we have been married.'" 
6. Communicators must remain focused on the goal of each transaction.

7. Communicators must be both assertive and gracious. 1

David W. Johnson and Frank P. Johnson suggests eight guidelines to bear in mind when sending a message.2

1. Clearly "own" your messages by using first person pronouns ("I" "My") . Personal ownership includes clearly taking responsibility for the idea and feelings that one expresses.

2. Make your message complete and specific. Include all the information necessary for the receiver to understand the message.

3. Make your verbal and non-verbal message congruent. Do not say one thing with your voice and another with your actions or facial expressions.

4. Do not be afraid to repeat yourself. Sending the same message more than once and using more than one channel of communication (such as pictures and written messages as well as verbal and non-verbal cues) will help the receiver understand your message.

'Jay E. Adams, The Christian Counselor's Manual (Grand Rapids, MI: Baker Book House, 1973), 65.

${ }^{2}$ Johnson and Johnson, 110 . 
5. Ask for feedback. To communicate effectively you must be aware of how the receiver is interpreting and processing your messages.

6. Make the message appropriate to the receiver's frame of reference. You would need to present the same information differently to an expert in the field and to a novice, to a child and an adult, to your boss and a coworker.

7. Describe your feelings by name (I feel sad), by action (I feel like crying), or by figure of speech (I feel down in the dumps). Description will help communicate your feeling clearly and unambiguously.

8. Describe others' behavior without evaluating or interpreting. When reacting to the behavior of others, be sure to describe it ("you keep interrupting me") rather than evaluating it ("you are a rotten, self-centered egotist who won't listen to anyone else's ideas"). ${ }^{1}$

Another indispensible element in interpersonal communication is the credibility of the sender. One lady said to me, "Pastor, I can't trust my husband at all. He is not trustworthy. He doesn't keep his word." No amount of communication techniques can help this husband in his communication with his spouse until he first brings his own credibility as a communicator into a state of repair.

${ }^{1}$ See Johnson and Johnson, 110. 
Part Four: Obstacles to Covenant Communication

In his book, The Power of Ethical Persuasion, 1 Tom Rusk lists five barriers to human communication:

1. We all live in unique and private worlds of personal experience.

2. Nearly everyone is insecure to some extent. Thus, when we feel threatened, hurt, or angry, we tend to react with blame and self-defense rather than with attempts to improve communication.

3. Everyone has difficulty handling strong feelings and maintaining a dynamic balance between mind and heart.

4. Feelings are facts to the person experiencing them. Rejecting a person's feelings makes the person feel rejected as a whole.

5. We almost always perceive some kind of power imbalance in difficult communication, but we rarely discuss power openly.

When applying these five barriers to covenant communication in a marriage, it will be helpful for couples to ponder the following points:

1. To what extent do I acknowledge and respect my partner's point of view? Am I always willing to learn

\footnotetext{
${ }^{1}$ Tom Rusk, The Power of Ethical Persuasion (New York: Penguin Books, 1993), 9.
} 
something new about my partner's world and personal experience?

2. Am I willing to admit fear or insecurity as a means of improving understanding? Do I prefer to resort to blaming my partner or defending myself instead?

3. When do strong feelings seem to interfere with my partner's ability to be reasonable and considerate?

4. Am I more engaged in determining "right" and "wrong" than in respecting each other's feelings and viewpoints?

5. Am I willing to discuss respectfully any real or perceived imbalances of power in my marital relationship?

All human communication, whether between children at play or diplomats trying to avert war, reflects this pushand-pull tension between self-protection and openness. As husbands and wives and parents, we often avoid saying what we really think and feel for fear of provoking one another. We defend this habit by saying that we do not want to damage our relationships. Yet it is exactly this withholding that interferes with the openness necessary to create intimacy. ${ }^{1}$

One Example of Ineffective

Communication

Here is an excerpt from a discussion between a husband and a wife during one of my pastoral visits:

${ }^{1}$ Rusk, 9. 
Wife: "Tom, the pastor is here. Tell him what you want to tell him."

Husband: "You told the pastor that things are not going the way they shoud be going around this house."

Wife: "You are not honest with yourself. You are responsible for all the trouble we are going through in this family."

At this point, I intervened, suggesting to them a better way of dealing with their conflict. Blaming and accusing could not resolve the problem. Only active listening, mutual respect, and mutual understanding could achieve that result.

\section{One Example of Effective}

Communication

One evening at $100^{\prime}$ clock one neighbor knocked on my door. I could immediately read distress on her face. "What can I do for you?" I asked. "Come right away and talk to Dan. He wants to go away," she replied.

Here is an excerpt from the discussion between Dan and his wife, Lisa. (Dan and Lisa are fictitious names.) Pastor: "I am here to listen to both of you in order to see if I can help." Adding in a relaxed voice, "Who would start?"

Lisa: "The reason why I asked you to come, Pastor, is that Dan threatened to leave me and the children, and I love him and the children love him too." 
Dan: "My wife should know, Pastor, why I decided to act this way. I am depressed because of her attitude. I have provided for my family, as you can see. My wife humilates me in front of the children, which I don't like at all. She always contradicts when I speak, and this has been going on for a long time. Last time I got so depressed that I had to stay in a motel for a week. I am fustrated. I can't take it any longer."

Iisa: "I am sorry for what has happened. Pastor, whatever advice you have for us I will take." Happily, Dan did not leave Lisa. Both seem to be happier now. Since they are my neighbors I can testify to that.

It takes two to communicate effectively. This couple did not try to sabotage the conversation as in the previous case. Both were able to express their feelings without interruption. When Dan said why he wanted to leave, Lisa was able and willing to respond by saying, "I love him and the children love him too." She accepted part of the responsibility for the problem. The one apparently negative aspect was that they both spoke to me, a third party, rather than to each other. However, as often happens in delicate diplomatic negotiations, this third-party facilitation can be helpful when emotions between the parties are high. 
Three Hindrances to an Effective

Communication

1. The attitude that there is no point in communicating or continuing a dialogue is very damaging. Suppose Lisa had said, "Dan wants to leave. It is up to him. I won't discuss it with him." It is almost certain that Dan would have gone.

2. A second hindrance to communication is the idea based on a take-it-or-leave-it attitude. It is not enough to emit without being received. To be listened to--as well as to listen--is therefore essential. One lady said to me, "My husband sees only himself all the time. He does not care about my feelings at all."

3. Communication must be consistent if it is to be persuasive. Also, the words that we utter must coincide with the acts we do. In 1 John 3:18 we read: "Dear children, let us not love with words or tongue but with actions and in truth." Contradictory messages are harmful to a good relationship. We must send clear messages and we must be reliable and credible. Space does not permit me to list all the problems we find in communication.

\section{Part Five: Techniques for Enhancing Covenant communication}

Couples need basic communication skills to deal effectively with their marital problems. My personal experience affirms this. One of the first things said by a 
spouse having marital difficulties is, "My husband and I don't communicate," or "My wife does not know how to communicate." Communication skills are vital to lasting relationships.

There are four important elements in communicating:

1. The Sender and Receiver of the Message

In this discussion, the couple constitute the sender and receiver. An exchange does not take place unless one sends a message and the other receives it. According to Judith $A$. and James $G$. Sellner, the effectiveness of the exchange is determined by the physiological and psychological condition of the individuals as well as the perceived relationship between a couple. ${ }^{1}$

\section{Form of the Message}

A message can be conveyed verbally (in words) or non-verbally (in silence, or by action). A rigid posture can send as powerful a message as a few well-chosen words. So can a smile or a paternal pat on the head. A message can also be communicated in writing--through a letter--for instance. A mixed message is one in which your words contradict your action or body language. In my involvement with couples, I have discovered that they do not always mean what they say. This is often true when there is hurt, when emotion is high. A rule of thumb is to go by the person's action, not his/her words.

\footnotetext{
${ }^{1}$ See sellner and sellner, 57.
} 


\section{Content}

The content of a message can do four things:

(a) It can convey information. "I took your car to the garage, it will be ready at 4 P.M." "I bought your favorite soap."

(b) A message can transmit a feeling. "I feel unhappy" (with no smile on the face) or "I love you" (followed by a warm hug).

(c) A message can convey the desire to have power or authority over the other. "You should," or "Do what I say."

(d) A message can make a statement about your values, prejudices, or beliefs. "What is the use of your religion?" "You only care about one thing."

\section{Intent}

Effective communication requires that you be aware of your intent. Are you entering into this exchange to create more understanding, love, and intimacy? or are you more interested in changing or controlling the other person, getting your own way, or making your partner feel guilty or silly? If your intent is to build up your partner's selfesteem, or to create more understanding, love, and intimacy, your partner will likely remain open to what you have to say. In the long run, your communication will be more pleasing. But if your intent is to humiliate your partner, 
to make him or her feel guilty, your partner may become defensive and distant. Your exchanges, rather than promoting greater understanding, will lead to greater conflict.

\section{Five Techniques for Exploring}

Your Partner's Viewpoint

\section{Establish that your immediate goal is mutual} understanding.

When you realize that a communication is in trouble, you may try to say, "Look, it feels to me like things are getting out of hand. Can we back up a little and first make sure we really understand each other?" or "I don't feel like we are getting anywhere with this problem. Can we put a hold on finding a practical solution for the moment and simply compare our points if view in greater detail? I'd be happy to let you expand on your position first."

\section{Elicit your partner's thoughts, feelings, and} desires about the subject at hand.

You can begin by saying, "I have a problem and would appreciate your help" or "I need to be certain that I understand what you want to happen as a result of our meeting or discussion." If your partner seems to be getting upset, immediately say something like, "Am I doing or saying something/not doing or saying something that creates a problem for you?" or "You seem to be upset, unhappy, or irritated with me. Am I wrong?" If you notice that you are 
getting upset while your partner remains calm, you might put it this way, "Look, I have to tell you that I am beginning to feel uncomfortable (or a little upset) about this. So I need to be especially careful to make sure that I really understand what you are saying." or "Wait a minute. Something about the direction we are going just doesn't feel right to me. Perhaps I misunderstand. Would you mind going over what you've said so far?"

3. Ask for your partner's help in understanding him or her.

Try not to defend or disagree. you might say it this way, "I think I hear what you are saying, but I want to double check. Do you mean that?. . ." or "Since nobody is perfect, I might be quite wrong about what is going on, so I need you to explain . . ." "Maybe I'm jumping to conclusions, but to me what you are saying means that . . Exactly what do you mean? How does it feel to you? Am I getting it right?"

4. Repeat your partner's position in your own words to show you understand.

"Okay, I want to make sure that I've got this straight. You are saying that.. . Have I got that right? Is that correct?" Or "It's important to me that I really understand. Let me see if I can put what you are saying into my own words" or "So what you are saying is . . ." 
5. Ask your partner to correct your understanding and keep restating his or her position.

ways to say this might include, "Okay, I need to back up a little. What exactly did you mean when you said? . . " Or "Sorry, I guess I am jumping to conclusions. Tell me a little bit more about. . . so I can get this straight." "Thank you for setting me right on this. Let me know whether I've got it now. The way I would describe your position is . . ."1

Remember the foregoing techniques are designed to help couples communicate and express their feelings in a more effective way. Poor communication undermines the marital love relationship. As one lady in a counseling session said to me, "My husband can't communicate. That explains the trouble."

${ }^{1}$ I am indebted to Dr. Tom Rusk for some of these techniques. For more detail, see The Power of Ethical Persuasion, 70-80. 
CHAPTER 4

\section{COVENANT FORGIVENESS}

The purpose of this chapter is not to discuss the large theological problems involved in forgiveness, but to consider the benefit of forgiveness and see how it can be applied to marital covenant love relationships. My intention in writing this chapter is to help couples understand that husbands and wives can make mistakes. Thus there is necessity to forgive each other and to recognize forgiveness as a gift through which an injured person releases himself or herself from anger and resentment. This chapter deals with:

1. What is forgiveness? What are the three essential elements of forgiveness?

2. The six phases in the process of forgiveness

3. Biblical forgiveness

4. Covenant forgiveness as therapy.

J. A. Barker wrote:

Those who marry may not need to be freed from an idealization of each other and of marriage in order to become reliable companions and lovers. The dynamics of forgiveness maintain the momentum 
in marriage. The heartbeat of every marriage, as a Christian sees it, is forgiveness."

Barker continues:

This is the knowledge we may find ourselves sharing with those who come to be married: a vision of acceptance found within the love of God, caught in the sparkle of human love and never quite lost in the shadows. ${ }^{2}$

Failure can be disarmed through the miracle of forgiveness. Forgive your mate when his/her error has affected you. Urge your spouse to receive God's forgiveness and to forgive himself/herself. The act of forgiveness opens the door to healing. ${ }^{3}$

Remember Paul's advice, "And be kind to one another, tenderhearted, forgiving each other, just as God in Christ has forgiven you" (Eph 4:32). "Bearing with one another, and forgiving each other, whoever has a complaint against anyone, just as the Lord forgave you, so also should you" $(\operatorname{Col} 3: 13)$

Perhaps your partner's failure causes you to be late, which you dislike intensely. Maybe his failure costs him a bonus that you were counting on to buy that new love seat. Because of your partnership in marriage, your mate's mistakes and failures will affect you. Whatever the

\section{${ }^{1}$ Peter Chambers, Made In Heaven (London: n.p.,} 1988), 122 .

${ }^{2}$ Ibid. , 122,123 .

${ }^{3}$ Dennis Rainey and Barbara Rainey, Building Your Mate's Self-Esteem (San Bernardino, CA: Here's Life Publishers, 1966), 135. 
situation, mistakes carry a price tag. ${ }^{1}$ Why, then, should one forgive an erring mate? Can such forgiveness be truly therapeutic? If so, for whom? What is this thing called forgiveness, anyway? Let me now attempt some answers to these questions.

\section{Part one: What Is Forgiveness?}

Quite simply, when you forgive, you give up your right to punish. Forgiveness is an act of the will, a deliberate choice, which means you will not retaliate although you may feel the other person has wronged you. True forgiveness does not throw your mate's failures back at him/her or use them to hurt him/her!

Pure and free forgiveness gives us something we often do not deserve. This is how God relates to us His children. He has given us love when we deserve punishment. Forgiveness says, in effect, "I won't reject you for your failures. I choose to accept you fully just as you are and I won't remind you of your failures."2

Forgiveness stands with the open arms of a loving friend, ready to embrace. It is difficult for a mate to resist such complete and unselfish love. By removing the

\footnotetext{
${ }^{1}$ Rainey and Rainey, 135.

${ }^{2}$ Ibid.
} 
fear and rejection, one gives one's mate renewed hope to keep trying without fear of failure. ${ }^{1}$

According to Walter Wangerin, Jr., there are three elements that must be present in the act of forgiveness:

$$
\begin{aligned}
& \text { 1. Giving up } \\
& \text { 2. Giving notice } \\
& \text { 3. Giving gifts. }
\end{aligned}
$$

Giving Up

Forgiveness is a willing relinguishment of certain rights. The one sinned against chooses not to demand her rights of redress for the hurt she has suffered. The husband does not hold his spouse accountable for her sin, nor enforce a punishment upon her, nor exact a payment or any reparations from her. The wife does not make his life miserable in order to balance accounts for her own misery, although she might feel perfectly justified in doing so. The act of forgiveness is inconsistent with a tit-for-tat approach .

This is how Wangerin characterizes the act and the consequence of forgiveness:

In this way she steps outside the system of law, she steps into the world of mercy. She makes possible a whole new economy for their relationship. Not the cold-blooded and killing machinery of rules, rights and privileges, but the tender and nourishing care of mercy

${ }^{1}$ Ibid.

${ }^{2}$ Walter Wangerin, Jr., As for Me and My House (Nashville: Thomas Nelson Publishers, 1987), 79. 
always rejoices in the growth, not the guilt or the pain, of the other. This is sacrifice. To give up one's rights is to sacrifice something to one's self-something hard-fought for in the world. ${ }^{1}$

\section{Giving Notice}

Giving notice means that a man or woman will reveal to his/her spouse, as clearly as he/she can, what she/he has done. The purpose of this revelation is not to accuse. It is to inform.

with love and not with bitterness, he/she explains both her/his act and its consequences, remembering always that this communication is for her/his sake, the sinner's sake, and showing always in his/her countenance a yearning for her/his peace and happiness. This, too, is sacrifice. To react in a manner opposite to vengeance, to risk reopening wounds, and to seek to heal the one who sought to hurt--these are sacrifices of oneself. ${ }^{2}$

\section{Giving Gifts}

Wangerin notes that forgiveness is not just "giving up" and "giving notice." It is also the giving of gifts.

The receiver doesn't deserve it; the giver wants nothing for it. It is not a thanksgiving, because that is the return of one goodness for another. It is not a purchasing price, not even the price of marital peace, because that is hoping to buy one goodness with another. Forgiveness is not a good work which expects some reward in the end, because that motive focuses on the giver, while

\footnotetext{
${ }^{1}$ Ibid., 79, 80.

${ }^{2}$ Ibid.
} 
this kind of giving must focus completely upon the spouse. The one receiving cannot say, "because I have given something to you, now you must give something to me." That's no gift at all."

Rather, forgiveness is giving love when there is no reason to love and no guarantee that love will be returned. The spouse is simply not loveable right now! Forgiveness is repaying evil with kindness, doing all the things that love requires even when you do not feel the love, for you do love also on the "desert days" when you don't feel loving."

This is grace. For example, when a husband has heard his sin, so that he might anticipate, under the law, some retribution, but receives instead the gestures of love--only then can he begin to change and grow in the same humility that his wife has shown him. Gift-giving, in the sense in which I have used the term, ranks among the greatest of all sacrifices, for it is the complete "giving away" of one's self. ${ }^{3}$

The apostle Paul didn't say that love bears some things, that love believes only the best things, that love hopes for a reasonable period of time, or that it endures for a while. Paul said, "Love bears all things, believes all things, hopes all things, endures all things" ( 1 Cor

\footnotetext{
${ }^{1}$ Ibid., 80.

${ }^{2}$ Ibid., 80,81 .

${ }^{3}$ Ibid.
} 
89

13:6). Love is limitless. Love is to give infinitely, without end. ${ }^{1}$

\section{Part Two: The Process of Forgiveness}

Beverly Flanigan in her book, Forgiving the Unforgivable, ${ }^{2}$ proposes six phases in the process of forgiveness:

1. Naming the injury

2. Claiming the injury

3. Blaming the injurer

4. Restitution or balancing the scales

5. Choosing to forgive

6. The emergence of a new self.

\section{Naming the Injury}

The first phase of forgiving, naming the injury, has one overall objective--to help you interpret the meaning of your injury and your beliefs about it. Naming helps you isolate what you are going to forgive. Once you name what it is you must forgive, you will also come to recognize its true nature. ${ }^{3}$

\section{${ }^{1}$ Ibid.}

${ }^{2}$ Beverly Flanigan, Forgiving the Unforgivable: overcoming the Bitter Legacy of Intimate Wounds (New York: Maxwell Publishing Company, 1992), 74 .

${ }^{3}$ Ibid. 
To forgive your partner or anyone else, you will need to know what you are forgiving. To forgive a person for cutting your finger off when he/she has actually severed your arm at the shoulder is useless. In other words, when you forgive someone for injuring you, you should know what the injury is and what it really means for you.'

In Matt 18, Jesus outlines three steps by which to confront a sinner with his sin. I think that these steps can also be applied in this process called "naming the injury."

So, then, go to him. "Tell him his fault." The fault here is the injury. In the naming phase, you construct the meaning of the wound. You admit that you are harmed; you explore the dimensions of the injury. In naming the injury, you also identify the meaning of the injury in terms of its duration, controllability, consequences, and, to some lesser extent, its cause. Once these objectives are met, you are ready to move on to the next phase of forgiving because you now understand what you are attempting to forgive. ${ }^{2}$

${ }^{1}$ Ibid., 90.

${ }^{2}$ Ibid. 
Claiming the Injury

The second phase of forgiveness, claiming the injury, is a phase of taking ownership. You give up trying to pretend that nothing has happened. ${ }^{1}$

The first task of claiming is to say, "This is my injury; no one else's. Other people may have been hurt, too, but I cannot do anything about that." During the claiming phase of forgiving, the conversion from bitter to better begins--not to sweet as yet, but to better. Like the other phases, claiming involves tasks that require active work. ${ }^{2}$ Harmed people must say to themselves, "This is our situation. What do we want?" Then they need to separate their own damage from that done to other people, stake their claim to it, and begin to reform it to work to their advantage. Once this is completed, you not only understand, you also accept what it is you are trying to forgive.

When you claim your injury, you stop defending yourself against it. You stop rationalizing the behavior of the offender or providing justifications for his/her behavior. You give up trying to pretend that nothing has happened. ${ }^{3}$ Again, let us mention Matt 18:15. "So then. Go to him." Tell him his fault, as Jesus says, between you and him alone.

\footnotetext{
I'Ibid., 92 .

I'Ibid., 104 .

${ }^{3}$ Ibid., 93.
} 
Blaming the Injurer

The third phase of forgiving is blaming the injurer. Blaming means that you conclude that someone is accountable for causing something to happen and that what happened is wrong. Until someone can be blamed for an injury, you will spin your wheels over and over in the mire of the injury until you sink in a combination of self-blame, confusion, and rage. 1

\section{Flanigan explains:}

The first two phases of forgiving answer the question what? "What has happened to me? What has been harmed?" The third phase, blaming, answers the questions who? and why? "Who hurt me and why did she do it?" without an answer to these questions, you can be psychologically paralyzed, unable to move forward in life and certainly unable to forgive anyone. ${ }^{2}$

Many persons are uncomfortable with the idea of blaming. The discomfort may result from the biblical passage that says, "Judge not, that you be not judged. For with the judgement you pronounce, you will be judged, and the measure you give, will be the measure you get" (Matt 7: 1, 2). There is no doubt about it. A critical attitude towards others is unchristian. We must take care how we judge others since we will be judged by God who will hold us to account for our treatment of others.

\footnotetext{
${ }^{1}$ Ibid., 106

${ }^{2}$ Ibid.
} 
our judgments must be based on facts, not appearances. "Don't judge by appearances, but judge with right judgment," said Jesus (John 7:24, RSV).

Blaming the injurer means that you conclude that someone is accountable for causing something to happen and that what happened is wrong. This is not being judgmental. You tell the injurer his/her fault with the intent of healing.

\section{The Objective of Blaming}

To blame someone is, first of all, to hold that person responsible for causing an event to happen." "It is, second, to assert that the responsible person did something wrong. "12

People do not blame each other for good things, they blame each other when bad things happen. The story of Jonah is a good illustration of this. Because of Jonah's disobedience to the voice of the Lord, "the Lord sent a great wind on the sea, and such a violent storm arose that the ship threatened to break up" (Jonah 1:4, NIV). "The sailors said to each other, 'Come let us cast lots to find out who is responsible for this calamity." Jonah was responsible. Vs. 12 confirms this! "I know that it is my fault that this great storm has come upon you" (Jonah 7:12).

${ }^{1}$ Ibid., 108.

${ }^{2}$ Ibid. 
Thus, blaming has two steps. First, you must decide who caused something to happen. Second, you must decide that the responsible person was wrong. The person blamed has violated an accepted moral rule and is responsible for having done so. ${ }^{1}$ There is nothing bad or good about blaming. Blaming in its technical sense is holding someone accountable. ${ }^{2}$ Blaming requires action. Taking action gives people some control over events in their lives. ${ }^{3}$ The first action towards blaming is for a wounded person to decide who can be blamed for the injury. Who are the available "targets" of blame?4

In the case of Jonah, only one person on the boat was responsible for the danger. It would have been morally wrong to blame everyone for the crisis. Only Jonah was to blame. Jonah was the appropriate target.

Injured people need to be told that blaming is a positive step forward. But it is not, by any means, a place to land and stay; it is only a step on the way to healing. once you can blame, you know whom you must forgive. When you resolve the identity of the person to forgive, you are closer to accomplishing that goal. 5

\author{
'Ibid. \\ ${ }^{2}$ Ibid. \\ ${ }^{3}$ Ibid., 108, 109. \\ ${ }^{4}$ Ibid. \\ ${ }^{5}$ Ibid. , 123, 124 .
}


Three targets can be held to blame in injuries:

1. The injurer

2. The injured, or

3. A combination of the two. ${ }^{1}$

There are people whom you will sift through to decide if they are somehow to blame (e.g., in-laws, the "other woman," friends, etc.). ${ }^{2}$ After you have made the necessary determination and performed the act of blaming in a spirit of love and for the purpose of healing, you are ready to move forward. ${ }^{3}$

\section{Restitution: Balancing the} $\underline{\text { Scales }}$

The story of Zacchaeus, the tax collector who climbed a sycamore tree because he was too short to see Jesus in the midst of the crowd, conveys the meaning of true repentance and forgiveness (Luke 19:1-10). Zacchaeus determined to see Jesus and would let nothing hinder him. It was an opportunity not to be missed.

Zacchaeus made a decision in the presence of Jesus and in the presence of others. "And Zacchaeus stood, and said to the Lord, 'Behold, Lord, the half of my goods I give to the poor, and if I have defrauded anyone of anything, I restore it fourfold'" (Luke 19:8). He was determined to do

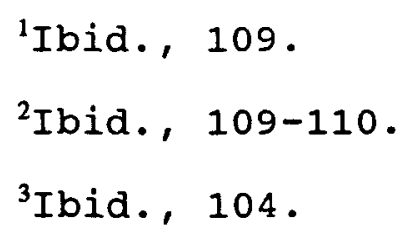


more than the law demanded. He showed by his deeds that he was a changed man. He was convicted of his sins, and chose to act on the conviction. Giving was a new experience for Zacchaeus.

God's forgiveness is a free gift that cannot be bought, but you can imagine how the local people would have reacted if the tax collector had announced that he accepted Christ as his Savior while keeping all the stolen money. Forgiveness always involves a cost to somebody. When you sincerely forgive, you give up all thoughts of getting revenge or demanding restitution. Your act of forgiveness has cost you something. You have given up all right to get even and have let God take care of meting out justice (Rom 12:17-19). In a somewhat similar fashion, Christ is able to forgive our sins because of the incredible price He paid when He willingly gave His life at Calvary.

How does this relate to making restitution or balancing the scales? First, if a person has broken the law and is legally guilty, he or she may have no alternative but to pay for the offense. The old Testament law required thieves and others to make restitution for their crimes and failures (Exod 22:3-6, 12; Lev 5:16; 6:5; 22:14; 24:18). Murderers were expected to pay with their lives (Lev 24:21). Today, law courts demand that legal of fenders pay for their wrongs by going to jail, by paying a fine, or 
sometimes by being put to death. Forgiveness for sins does not do away with legal justice.

second, when we have wronged another person who has forgiven us, it is a natural response to express gratitude by making restitution. However, like Zacchaeus, of ten the forgiven and grateful person is inclined to do all in his or her power to make things right.

Third, it is clear that making restitution often helps people accept the reality of their forgiveness. Forgiveness involves the principle of restitution whenever possible. There are some wrongs for which total restitution can be made. There are others for which only partial restitution is feasible.

In the case of zacchaeus, how could he find all those whom he had wronged? It would have been impossible for David to restore Uriah to Bathsheba (2 Sam 11:12).

In the case of a man who has divorced his first wife and married another woman, how does the adulterer make restitution to his former wife? What is the solution? Should people go around for the rest of their lives feeling guilty because they can never fully atone for a wrong? or is it enough for them to simply say, "The Lord has forgiven me, and that is all there is to it. I have no further obligation." Or shall they, after asking God's forgiveness and the forgiveness of the parties involved, put matters in 
the Lord's hands, willing to do what He directs--and when He. directs it?

Psychiatrist Mansell Pattison has distinguished between what he calls the reconciliation and the punishment models of forgiveness. In reconciliation, the forgiven person goes to the one he or she has wronged and seeks to make things right. If I steal your wallet and then seek your forgiveness, I must give back everything I have taken. This is not because your forgiveness depends on my returning the wallet, but because I want to restore what belongs to you, and I know that restitution increases the possibility of rebuilding our relationship. ${ }^{2}$ Beverly Flanigan puts it this way: "Balancing the scales returns power or resources to a wounded person because it restores that person's options and helps him to believe that fairness has returned to his life." ${ }^{3}$

\section{Choosing to Forgive}

What does the choice to forgive really mean? It means you no longer consider that the person who injured you

${ }^{1}$ Donald Ernest Mansell and Vesta West Mansell, Sure as the Dawn (Hagerstown, MD: Review and Herald Pub. Assn., 1993), 241 .

${ }^{2}$ Gary R. Collins, The Biblical Basis of Christian Counselling for People Helpers (Colorado Springs: NavPress, 1984), 145 .

$$
{ }^{3} \text { Flanigan, } 128 \text {. }
$$


owes you anything. It means that you set the injurer free. ${ }^{1}$ This is exactly the meaning of forgiveness. The Greek word aphiemi, means "let go," "cancel," "remit," "leave," "forgive."

It means that you do not look back. You no longer look at why the injury happened, you look at what you will do in the future. ${ }^{2}$ Choosing to forgive is a turning point, actually a pivotal point, in a person's life. Once the choice is made, a brand new life lies ahead.3

The following example will illustrate: Nancy had only one daughter. Nancy's daughter was intelligent, beautiful and considerate. A certain young man coveted. Nancy's daughter. The young lady was raped and killed. The killer was apprehended by the police and incarcerated. Nancy demanded the death penalty. She became disturbed. She became confused. She was losing her appetite, she could hardly sleep. Her health was deteriorating. She was becoming thinner and thinner.

She consulted her family doctor. After a thorough examination, the doctor recommended that she rest for a few weeks. Still her condition became increasingly complicated. After another lengthy consultation, Nancy's physician told her that her problems lay in her unforgiving attitude. If

\footnotetext{
I'Ibid., 144, 245

${ }^{2}$ Ibid. , 145

${ }^{3}$ Ibid.
} 
she wanted to regain her health, she would have to forgive her daughter's murderer.

Nancy decided to forgive. She bought a beautiful Bible. She wrote a nice letter. Then she went to the jail and obtained permission from the warden to say a few words to the prisoner. "I forgive you with all my heart," she told the man whose act had caused her so much pain. "I choose to forgive you." Nancy regained her health and her joy .

Jesus said, "Love one another as I have loved you." This was the love enacted on the cross. The sacrificial and self-emptying love, the love of forgiveness. Sin has obliterated the image of God from many marriages. Divorce has affected the covenant love relationship between God and His children and between husbands and wives. However, with the gift of mercy, seized by a strong faith and with the aid of the Holy Spirit, agape love can become once again a reality in marital life.

When you forgive someone, you say to yourself, "The person who hurt me is no longer responsible for the way my life will go. I am responsible now." Many of us would like to have someone else around to blame for our bad fortunes, but when you decide to make no demands on the injurer, you release that person from any responsibility for your fortunes. You become proactive. You become once again 
the true steward of your personal destiny. This is part and parcel of the reward we receive when we choose to forgive.

\section{The Emergence of a New Self}

As Janet' put it, "If something devastates your life, a complete reorganization begins. I needed a whole new philosophy about people." You remember the story of Nancy mentioned earlier. Nancy became a new person after she realized that she could no longer harbor ill feelings against her daughter's murderer.

The final phase of forgiving is called the emergence of the new self. It is in this phase that the word "forgiving" begins to make sense. The two parts of the word forgiving--"for" and "giving"--suggest the idea that a wound exists for the purpose of giving; in other words, wounds exist to give us a chance to give up one thing and begin something else. ${ }^{2}$

People who forgive choose not to dwell in the past but to look to the future. Jesus christ, the source of forgiveness, forgave Peter for denying Him. He encouraged him to move forward. "Feed my sheep. . . . Feed my lambs" (John 21:15-17). Now that Peter was forgiven, there was a new task before him. He was to learn from, but not to live in, the past. The same holds true today both for those who

\footnotetext{
${ }^{1}$ Real person but fictitious name.

${ }^{2}$ Flanigan, 162 .
} 
choose to forgive and for the beneficiaries of the act of forgiveness.

In Rom 6:28, Paul says, "And we know that in all things God works for the good of those who love Him, who have been called according to His purpose." Some harm we can control; some we cannot. Remember the serenity Prayer, "God grant me the serenity to accept the things I cannot change, the courage to change the things I can, and the wisdom to know the difference."

When you forgive a person who has hurt you, and that person may be your own partner, you say. in reality:

Harm comes to every one; moral contracts cannot prevent injury; no one is immune from it, but a larger force (usually God) has a reason, however mysterious, for injuries that befall people. People may suffer, but the suffering has a larger purpose. The test of a person's character is how well he functions even when he cannot understand God's plan for him.'

\section{Part Three: Biblical Forgiveness}

How to Forgive

The Greek word for forgiveness is aphiemi. It is used often in the New Testament, especially in the Gospels, and means "send away from oneself" (Matt 13:36:); "let go" (Matt 4:20); "turn away" (Matt 19:29; 1 Cor 7:10); "pass "forgiveness." 
over" or "neglect" (Heb 6:1)." Hence it is used in the sense of remitting a debt (Matt 18:27; 6:12, 14). The creditor tears up the bill, so to speak, or never enters the debt in the ledger. ${ }^{2}$

side by side with these instances, however, we must put the noun "aphesis," meaning release, pardon, cancellation, forgiveness, (paresis); letting pass, passing over. ${ }^{3}$

The forgiveness denoted by aphiemi and paresis is almost akin to the forgiveness we receive from God. In the Synoptics (cf. Acts $8: 22$; Ja 5:15), this is mostly a forgiveness to which man is continually referred and which he can receive on request so long as he is ready to forgive others (Matt 6:12,14f.; 18:21,35; Luke 17:3f; Mark 11:25). To this extent, the concept is the same as the old Testament and Jewish ideas of forgiveness. Yet there is a new and specifically Christian feature, for the community realizes that it has to receive from God the forgiveness that is offered to man through the saving act that has taken place in Jesus Christ. ${ }^{4}$ Aphiemi is used 142 times in the New "forgiveness."

${ }^{1}$ Dictionary of The Apostolic Church (1926), s.v.

${ }^{2}$ Ibid.

${ }^{3}$ The New International Dictionary of New Testament Theology (1975), s.v. "forgiveness."

4Theological Dictionary of the New Testament (1994),
s.v. "forgiveness." 
Testament. Of these examples, 47 are found in Matthew, 34 each in Mark and the Lucan writings, and 14 in John. This leaves only 13 examples in the rest of the New Testament. ${ }^{1}$ Forgiveness includes making of no account the sin which has been committed (Mark 2:5; John 8:11). It also means the acceptance of the sinner (Luke 15:20ff.). Christ taught not only the duty of forgiveness or repentance, but also that it was to be unlimited both in quality and quantity. No offense was so serious, no repetition of offense so excessive that forgiveness might be withheld, provided only that penitence was shown.

\section{Unlimited Forgiveness}

In Matt $8: 22$, Christ shows that

Forgiveness is not a matter of mathematics or legal regulations, but an attitude. He who harbors within himself the idea that at some future time he will not forgive, is far from extending true forgiveness even though he may go through the form of forgiving. ${ }^{2}$

If the spirit of forgiveness activates the heart, a person will be as ready to forgive a repentant soul the eighth time as the first, or the 491 st time as the eighth. True forgiveness is not limited by numbers. Furthermore, it is

\section{${ }^{1}$ The New International Dictionary of New Testament Theology (1975), s.v. "forgiveness." \\ ${ }^{2}$ Seventh-day Adventist Bible Commentary, Vol. 5 (Washington, DC: Review and Herald Pub. Assn., 1956), 449.}


not the act that counts, but the spirit that prompts the act. "Nothing can justify an unforgiving spirit."1

Receiving and Extending Forgiveness

When Jesus taught His followers to pray, He included the following verses:

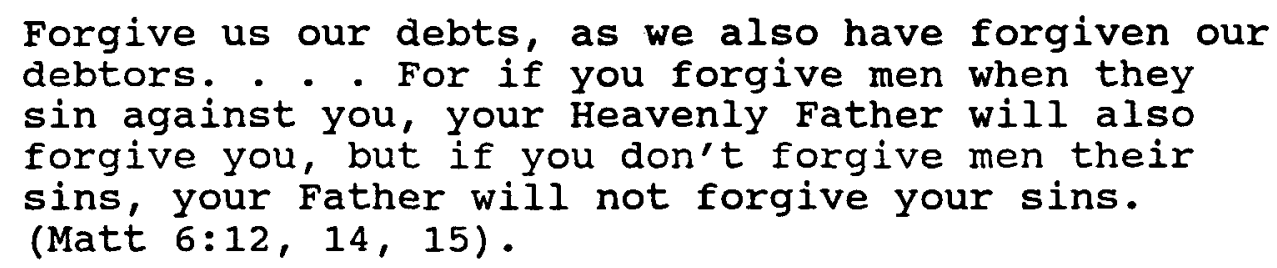

Forgiveness, then, clearly has two features. We ourselves need forgiveness and we must extend forgiveness to others.

Jesus warns in Matt 6:12, 15 that we cannot expect God's forgiveness if we are unwilling to exercise forgiveness towards others. Remember your own particular fault, remember the specific and healing grace of God for you. Remember, and you will find it difficult to approach your spouse in pride. If you did not commit sin against your spouse, certainly you did once against your parents, your schoolmates, your friends, your colleagues, or some other group. Or you did in your heart what you did not have the temerity to do openly with your hands.

${ }^{1}$ Ibid. 
The theologian William Barclay states that "there is. no reckonable limit to forgiveness."1 Alluding to the story of the debtor, Barclay further comments:

It teaches that lesson which runs through all the New Testament--a man must forgive in order to be forgiven. He who will not forgive his fellow men cannot hope that God will forgive him. "Blessed are the merciful" said Jesus, "for they shall obtain mercy." As James said, "For judgement is without mercy to one who has shown no mercy" (James 2: 13). Divine judgement and human forgiveness go hand in hand.

If God has forgiven all, how much more should a man or woman be ready to forgive the partner who has done wrong!

Forgiveness in word and Action

Jesus prayed for those who crucified Him, "Father forgive them, for they know not what they do." He washed the feet of the one who was going to betray Him. He graciously pardoned Peter for his denial of Him, then He reincorporated him into the apostolic circle.

It was the French philosopher Moliere who wrote this: "Men are alike in their words, but their actions differentiate among them." Jesus, the source of forgiveness, did not merely utter the words "I forgive you" but by His actions He demonstrated the spirit of forgiveness. Said Jesus, "If I, then, your Lord and Teacher, have washed your feet, you also ought to wash one

${ }^{1}$ William Barclay, The Daily Study Bible: The Gospel of Matthew (Toronto, Canada: G. R. Welch Co, 1975), 2:192.

$$
{ }^{2} \text { Ibid., 194, } 195 .
$$


another's feet. For I have given you an example so that you also should do as I have done to you."

Forgiveness, on the part of either God or man, is much more than a judicial act. It is a restoration of peace where there has been conflict (Rom $5: 1$ ). But it is even more than that. It includes the effort to restore the erring person himself (Gal 6:1). Applied to the marriage covenant, this idea implies that husbands and wives must pledge themselves to love each other unconditionally and to be always willing to overlook each other's frailties. Therefore I must be willing to forgive and accept my partner as long as I would like God to forgive and accept me. I am very much in agreement with Bacchiocchi's explanation of forgiveness:

In a covenant marriage, we recognize the sin that our mates have committed against us. We don't explain away the sinful behavior of our mates by saying "He did not mean what he said," or "probably I deserve what he did to me" or "I don't feel really hurt by what he did to me." Rather, we realistically recognize that we have suffered wrong, but we don't allow such wrongs to weaken our mutual commitment. Why? First, because we recognize that we are sinful beings who sometimes hurt each other terribly. We violate the deepest trust of our mates. We trample upon their unconditional love. Secondly, because we realize that since God can forgive our mates, so can we."

Bacchiocchi continues:

Forgiveness in a marriage covenant must be as unconditional as Christ's forgiveness to us. . . God forgave us in Christ, not after we promised to reform and obey, but "while we were yet sinners" 
(Romans $5: 8$ ). In the same way we must forgive our mates not only if they promise never to wrong us again, but simply because God in christ has forgiven.

Genuine forgiveness makes us free to love, to trust, and to grow with our mates. It enables us to break the cycle of retaliatory attacks. If we have been wounded by the words or actions of our mates, we refuse to retaliate by returning words or actions in kind. ${ }^{1}$

Let us remember that forgiveness is more than an act of the will. The heart must also be engaged. In fact, every faculty is mobilized in forgiveness: sensitivity, heart, intelligence, judgement, imagination, faith, etc. John Eadie, in his commentary on Eph 4:32, has this to say:

Instead of resentment and retaliation, railing and vindictive objurgation, Christians are to pardon offenses--to forgive one another in reciprocal generosity. Faults will be committed and offenses must come, but believers are to forgive them, are not to exaggerate them, but to cover them up from view, by throwing over them the mantle of universal charity. ${ }^{2}$

In the case of marital covenant love relationship, husbands and wives are to be full of deep and mellow affection, in opposition to the wrath and anger that they are summoned to abandon. A rich and genial sympathy should ever characterize all their intercourse. The measure and

${ }^{1}$ Tbid., 116

${ }^{2}$ John Eadie, A Commentary on the Greek Text of the Epistle of Paul to the Ephesians (Grand Rapids, MI: Baker Book House, 1979), 360 . 
motive of this universal forgiveness are stated in the phrase "as also God in Christ forgave you."

Kathōs kai - "as also"--is an example with an implied comparison. It is an example that Christians are bound to imitate. They are to forgive because God has forgiven them, and they are to forgive in resemblance of $\mathrm{His}$ procedure. ${ }^{1}$

In the exercise of Christian forgiveness, His authority was their rule, and His example their model. They were to obey and also to imitate--nay, their obedience consisted in imitation. "In Christ," as the element or sphere, signifies not "on account of or by means of christ," but as revealed in christ, acting in Him, speaking in Him, and fulfilling His gracious purposes by Him as the one Mediator. ${ }^{2}$ Christ's pardon is full, free, and irrevocable. Now, because God has pardoned us, we should be ready to pardon others. His example at once enjoins imitation and furnishes the pattern. Thus the offenses of others are to be pardoned by us fully, without retaining a grudge, and freely, without requiring any reciprocal measure. We must forgive not only seven times, but seventy times seven. Once pardoned, those who hurt us are not to be raked out of

'Eadie, 361.

${ }^{2}$ Ibid. 
oblivion, and again made the theme of collision and quarrel. ${ }^{1}$

\section{Part Four: Covenant Forgiveness as Therapy}

Researchers Michael McCullough and Everett Worthington concisely define forgiveness as a complex combination of

effective cognitive and behavioral phenomena in which negative effect and judgement toward the offender are reduced, not by denying one's right to such effect and judgement, but by viewing the offender with compassion, benevolence and love, while realizing that the offender has no right to them.

In their research studies on forgiveness, Mccullough and Worthington were able to demonstrate that forgiveness can lead to restored relationships and to restored peace of mind for both partners. When people forgive, there are decreased feelings of revenge, more positive feelings among every one involved, and more efforts to bring about reconciliation. ${ }^{2}$

Robert C. Roberts, Professor of Philosophy and Psychological studies at wheaton college, proposes forgiveness as a way of overcoming anger. He declares:

Anger degrades our lives in many ways. It messes up our marriages, alienates us from our children and our parents, destroys friendships, depletes our energy reserves, and distracts us from getting

${ }^{1}$ Ibid.

${ }^{2}$ Collins, The Biblical Basis of Christian Counselling for People Helpers, 146. 
on with the important things in life. It can cause anxiety, depression, guilt and despair, and it can lead loneliness and hatred in our life.

Roberts continues:

Besides all these "relational and psychological" problems, sustained anger causes, I am told, such bodily problems as heart disease, high blood pressure and stomach ulcers. If Christianity empowers us to forgive, surely it is a very therapeutic view of life. ${ }^{2}$

Richard Nixon once said, "When you hate others and refuse to forgive, you are the one who really loses in the end. When there is forgiveness between people, the forgiver and the offender both benefit."

In his book, Stress Without Distress, Dr. Hans Selye, recognized as the world's foremost authority on stress, has stated that hate causes stress and love eliminates it. He asks, "If everyone loved his neighbor as himself, how could there be any war, crime, aggression or even tension among people?"13

The problem, wrote Dr. Selye, is that, "if we don't somehow modify our built-in selfishness, we arouse fear and hostility in other people."4

${ }^{1}$ Robert C. Roberts, Taking the word to Heart: Self and other in an Age of Therapies (Grand Rapids, MI: Eerdmans, 1993), 190.

${ }^{2}$ Ibid.

${ }^{3}$ Hans Selye, Stress Without Distress (New York:

J. B. Lippincott Co., 1974), 35 .

${ }^{4}$ Ibid. 
Professor Jean Monbourquette recounts an incident of . forgiveness as therapy:

I was an eyewitness to a psychological, indeed a physical healing which followed an exercise of forgiveness. I received in therapy a university professor of deep faith. His industrious attitude and his marital problems brought him to the brink of depression. Furthermore he was suffering from ulcers. I asked him to admit his frustration, his anger against his alcoholic wife, his son (a victim of drugs), and his daughter's infatuation with a young man whom he detested. I suggested to him to forgive each of them. Two weeks later the university professor announced that he had no more ulcers and that his health was drastically improved.

In his book, Loving Each Other, Leo Buscaglia recounts another cure of forgiveness. It concerned a husband and wife who had gone to a prison to embrace, in forgiveness, a man who had raped and murdered their twentytwo-year-old daughter. Bob and Goldie Bristol told of the horror and pain they felt on learning of their daughter's murder. They revealed their eventual decision to leave retribution to heaven. Fortified with a deep sense of religious faith, they decided to embrace their enemy in love. After many attempts to reach Tom (the fictitious name they assigned to their daughter's slayer), he finally agreed to see them. Mrs. Bristol described their meeting in prison in touchingly simple language:

\footnotetext{
'Jean Monbourquette, Comment Pardoner (Ottawa, Canada: Novalis Centurion, 1992), 12, 13 (translation by Vaudre Jacques).
} 
The door opened, Tom entered the room. He was about six feet tall, dark haired and muscular, cleanly dressed and shaven. . . A person. God's love welled up within me and overflowed. Tom paused, his eyes filled with tears. My husband and I stood and each in turn embraced Tom. We wept together.

She frankly admitted that they did not understand the "why" of his brutal action. They simply allowed themselves to experience his humanness--the aspect of Tom they were able to identify with, understand, and accept.

After their meeting, they felt free, purged of anger and resentment. Even their pains disappeared.2

Asking for forgiveness and forgiving others are complicated processes that involve deep sympathy, humanity, and wisdom. Historically, we have found that without forgiveness there can be no lasting love, no change, no real growth, no freedom. ${ }^{3}$ Dr. Gerald Jampolsky is right when he states: "Hate, bitterness and vindictiveness are overpowering, self-defeating and intellectually as well as emotionally depleting."4

But we must remember that to be forgiven and to forgive involve the same dynamics. If we hope to be forgiven for wrongdoing, then we are compelled to forgive

\footnotetext{
${ }^{1}$ Ibid.

${ }^{2}$ Ibid., 94 .

${ }^{3}$ Ibid. , 95.

${ }^{4}$ Dr. Gerald Jampolsky, cited in ibid.
} 
also. If we are unable to forgive, we cannot expect others to forgive us. ${ }^{1}$

Again, the question arises: Why should we forgive? We forgive, for the price we pay for not forgiving is too great. To bear grudges, to harbor hate, to seek revenge, are all self-defeating and lead us nowhere. They neither satisfy nor heal. They keep us from moving forward and starting again. They bury positive energies in negative actions which serve only to exhaust and deplete us. They keep us suspicious and hesitant to trust again. They destroy our creativity, and retard our growth. ${ }^{2}$

It is certainly for this therapeutic benefit that Jesus instructed $\mathrm{His}$ followers to forgive (Luke 17:4). On another occasion, He spoke with disapproval about the servant who was forgiven a large debt, but then refused to forgive the much smaller debt of a fellow servant (Matt $18: 23-35)$.

The aim of forgiveness is reconciliation, God does not want brothers and sisters to live in estrangement. As Roberts puts it:

The aim of christian forgiveness is not to rid the forgiver of an unpleasant and disruptive emotion but to strive toward the attitudes and relationships characteristic of God's Kingdom. Forgiveness is therapy, and love is the health at which it aims. ${ }^{3}$

Forgivers are persons of integrity who do not play mental games with themselves. They do not shy away from the

\footnotetext{
${ }^{1}$ Ibid.

${ }^{2}$ Ibid., 104 .

${ }^{3}$ See Robert C. Roberts, 199.
} 
moral seriousness of the offense, but they have morally and spiritually proper reasons for overcoming anger. ${ }^{1}$

Forgiveness is an aspect of mental health. We are instructed to "be perfect" as our Heavenly Father is perfect (Matt 5:48), and part of this perfection is found in our forgiving one another as God in Christ forgave us (Eph 4:3251)..$^{2}$

No doubt, the forgiving spirit will increase a person's freedom from emotional pain as well as from ulcers and hypertension. Ps 32 contains insights and much helpful advice about the relationship between forgiveness and the well-being of the forgiver. David showed his understanding of repentance and forgiveness when he wrote:

Blessed is he whose transgressions are forgiven, whose sins are covered. Blessed is the man whose iniquity the Lord does not count against him and in whose spirit is no deceit. When $\dot{I}$ kept silence, my bones waxed old--through my roaring all the day long. For day and night thy hand was heavy upon me. My moisture is turned into the drought of summer (Ps $32: 1-4$, RSV).

When David refused to confess, he experienced severe mental conflicts and resultant physical suffering! Professor Jean Monbourquette, to whom I referred earlier, said that several times his client (the university professor) shed tears when it was his turn to ask forgiveness for his long absences from home, his lack of

\footnotetext{
'Ibid., 194 .

${ }^{2}$ Ibid.
} 
general interest toward his alcoholic wife, and for his anger toward his son and daughter.

Jesus is very specific in Matt 6:12: "Forgive us our debts, as we also forgive our debtors." we need to receive forgiveness and to extend forgiveness to others. Someone writes, "I made a distinction between forgiving in the head and forgiving in the heart. Not to forgive in your heart destroys your health and your heart. People should know, though, that it is hurdle after hurdle." Another person declares: "Not to forgive means not being the person you want to be. Not forgiving can do terrible things to a person. It changes you."

Janet wrote:

Forgiveness is a virtue, I think. Anger brings you nothing. No sleep, no smiling. Then it spurts out into other areas. . . God doesn't want us to be miserable mentally or physically. If you are harboring anger or wanting revenge, you are not doing God's will for you. You are not allowing yourself to be the person God wants you to be. Forgiveness is a fantastic way to live. It releases you from so much. You can never again be so angry. Never as intense. Never for so long. I think it's one of the most important things to be able to do. It is accepting the fact that no one is perfect. ${ }^{1}$

${ }^{1}$ These are fictitious names. 


\section{CHAPTER 5}

\section{SURVIVAL TECHNIQUES FOR ENHANCING \\ MARITAL COVENANT LOVE}

\section{Introduction}

My aim in this chapter is twofold: (1) to help couples become conscious of those factors that inhibit their ability to enhance their marital relationship; and (2) to provide them with some relevant survival techniques on how to deal with those factors. With mutual goodwill, understanding, and tenderness, a couple can resolve by themselves the unavoidable difficulties of life together.

\section{Part one: Hindrances to Marital Covenant Love}

"A good relationship consistently delivers pleasure while also keeping painful experiences at a minimum."1 Positive, pleasurable emotions benefit your physical and mental health, and the momentum they create sustains the

${ }^{1}$ Harriet B. Braiker, Lethal Lovers and Poisonous People: How to Protect Your Health from Relationships That Make You Sick (New York: Pocket Books, 1992), 227. 


\section{8}

motivation necessary to continue to improve the quality of your relationship.'

If couples want their marital covenant love to grow, they must build opportunities for fun, pleasure, playfulness, and humor into their relationship. Sharing fun and pleasurable experiences with your partner helps create more positive associations relative to the relationship. Generally, this is true simply because you tend to like people with whom you have fun; and you also are likely to attribute other positive qualities to your partner if he or she provides you with pleasure. ${ }^{2}$

What are the factors that can inhibit one's ability to enhance one's marriage relationship. Dr. Pierre Lanares, in his book the secrets of Love, enumerates seven obstacles to durable conjugal love:

1. Lack of knowledge

2. Lack of love expression

3. Lack of adaptation to different stages of life

4. Lack of spiritual and moral communion

5. Lack of intimacy

6. Prolonged absence

7. Outside influences. ${ }^{3}$

${ }^{1}$ Ibid., 228.

${ }^{2}$ Ibid.

${ }^{3}$ Lanares, 227 . 


\section{9}

Now let us take a closer look at each of these seven enemies.. of covenant love relationships.

\section{Lack of Knowledge}

When we buy a car, we receive with it a manual

telling us how to go about its maintenance. We attentively study its function. We appreciate the advantages and determine the inconveniences.

often, however, we ignore everything about the person who is going to be our life's companion. More often the choice of a partner is limited to the physical aspect, and ignores consideration of his or her background.

Knowing the traits of one's partner places the spouse at a vantage point. Knowing what to expect will prepare the partner for the challenges he or she can face. Knowing what to hope for will inspire the partner to take the journey. Harry stack sullivan says it nicely: "Throughout our lives opportunities for new integration and adaptation present themselves." "The secret of success in marital covenant love is diligence and healthy motives on the part of each partner. A superficial exchange is not enough. It is dangerous to refuse dialogue. There should be no hidden agenda between spouses. Strengths and

${ }^{1}$ Henry Stack Sullivan, quoted in Hendrix, 227. 
weaknesses should be revealed. Hence the necessity of humility and openness.

\section{Lack of Love Expression}

Love is like a garden. It needs to be taken care of. Love that does not exteriorate etiolates. There are simple ways to express one's tenderness: a smile, a tender look, etc.

One of the clearest ways to demonstrate your love is to do something unselfish or altruistic for your partner. The act need not be a grand gesture. On the contrary, small actions, performed consistently and done for your partner's benefit, instead of yours, will add up to a strong, ongoing expression of love.

Here are some ways in which a couple can express love.

1. Take a few minutes to thoroughly observe each other's physical appearance. Openly state at least three things that you like about your partner's appearance.

2. Say what you consider your partner's three greatest personality or character strengths; provide clear behavioral examples to illustrate each.

3. Mention at least one positive way in which your partner is special or distinct from most other people you know; give examples; explain why you value this in your partner. 
4. State at least two things that you think your partner does particularly well; give clear examples.

5. Tell your partner in what way(s) you would like to be more like him or her; give examples; say why you value this trait in your partner.'

Lack of Adaptation to Different Stages of Life

Conjugal harmony during the first marital years can be broken by a lack of adaptation during the coming of children. That is why at the beginning of love, we must prepare our heart to open up and to share. We must also anticipate the gloomy hours of life. Life is not always rosy. Life is often difficult and complex. Life even has surprises sometimes. When challenges arise in the form of financial difficulty, accident, or illness, it is good for the partners to remember the beautiful formula, "for better or for worse. . till death do us part."

As Elizabeth Achtemeier put it,

I will be with you, no matter what happens to us and between us. If you should become blind tomorrow, I will be there. If you achieve no success and attain no status in society, I will be there. When we argue and are angry, as we inevitably will, I will work to bring us together. When we seem totaliy at odds and neither of us is having needs fulfilled, I will persist in trying to understand and in trying to restore our relationship. When our marriage seems utterly sterile and going nowhere at all, I will believe that it can and $I$ will want it to work and $I$ will do my part to make it work. And when all is wonderful and we are happy, I will rejoice over our life together, and

\footnotetext{
${ }^{1}$ Braiker, 194-195.
} 
continue to strive to keep our relationship growing and strong. 1

Healthy partners who survive the stresses and the vicissitudes of life do so by reminding each other consistently and consciously of what each can do to increase their sense of control in the eye of a storm; that difficulties can be seen as challenges that strengthen their bond as they cope with problems together; and that, whatever happens, their mutual commitment is to love each other well, to value life by protecting their health, and to make each other happy.

Such a total commitment is possible only by divine grace. It is God who gives us power to hold fast to our commitment. What is true for salvation is also true for a committed marriage: there is both a divine initiative and a human response. As Paul puts it, "Work out your own salvation with fear and trembling; for God is at work in you both to will and to work for His good pleasure" (Phil 2:1213). We must work to achieve total permanent commitment in our marriage and yet recognize that it is God who is at work in and through us to make this goal possible. ${ }^{2}$

${ }^{1}$ Elizabeth Achtemeier, The committed Marriage (Philadelphia, PA: Westminster Press, 1976), 41.

${ }^{2}$ Bacchiocchi, 46 . 


\section{Lack of Spiritual and Moral Communion}

\section{Dr. Bacchiocchi explains:}

Most marital conflicts can be resolved when husband and wife enjoy a healthy fellowship with God. If one or both partners loses this fellowship, then the possibility of resolving conflicts is greatly reduced because they are no longer able to bring their problems together to the Lord in prayer and seek His solution."

According to Gary R. Collins,

religion can be a binding, strengthening force in a marriage, but when a husband and wife have different viewpoints, religion can also be a focus for marital tension. ${ }^{2}$

Life divides couples. One partner may have to work in the morning, the other at night. Therefore, one common faith, the submission to the same religious conviction, can be a capital element of comprehension and cohesion.

The couple should create their own personal time of spiritual study and prayer. If the christian couple presents a healthy christian model, the children will be influenced by it. Practicing religious faith can promote social health and facilitate self-healing for injured emotions. Harriet B. Braiker states:

If you are a spiritual person, availing yourself of the benefits of practicing your faith is a powerful antidote to toxic emotions. If you and your partner are of the same religion, practicing your faith together may help neutralize some of the toxic feelings between you. In particular, the antidotes of love and forgiveness are pervasive themes in sermons and religious liturgy. Strengthening your faith will help

\footnotetext{
${ }^{1}$ Ibid. , 96.

${ }^{2}$ Collins, Christian counseling, 412 .
} 
to counteract hopelessness, depression, anxiety, helplessness, and loss of control.

In addition, belonging to a christ-centered organized church offers strong social support systems to both individuals and couples.

\section{Lack of Intimacy}

The people in our lives might be divided into three groups. Acquaintances are people whom we know only casually. Friends are closer. They are people who care for one another, spend time together, and have similar interests and viewpoints. Intimates have all the characteristics of friends, but they also share mutual concerns and personal struggles. Intimate friends understand each other and experience a level of acceptance, loyalty, vulnerability, accountability, caring, empathy, and love that is not present in a mere friendship. In marriage, intimacy includes sexuality, but it should not be assumed that all intimacy involves sex. ${ }^{2}$ Life conditions may affect the intimacy of the couple. The smallness of an apartment and the scantiness of money may complicate existence and prevent in-laws from living by themselves. Often the presence of parents aggravates an already difficult situation. Such cohabitation, albeit inevitable, may not be conducive to the unity of the couple.

\footnotetext{
${ }^{1}$ Braiker, 194-195.

${ }^{2}$ Collins, Christian Counseling, 189-190.
} 
The frequent presence of friends also risks disturbing the conjugal life. When young adults fail to develop intimacy, writes Erikam, the future is more difficult. ${ }^{1}$

The effort required to build intimacy and to keep love alive is as intensely rewarding as it is demanding. The challenge of keeping the covenant marital relationship honest, vital, loving, and solid requires that the couple rise to their finest self. But by doing so, their love for each other is enhanced.

\section{Prolonged Absence}

The apostle Paul, knowing full well how absence can fracture intimacy and destroy the marriage relationship, counsels:

Do not refuse one another except perhaps by agreement for a season, that you may devote yourselves to prayer; but then come together again, lest satan tempt you through lack of self control (1 Cor 7:5).

"Married couples have the responsibility to care for each other; therefore, husbands and wives should not withhold themselves sexually from one another, but should fulfill each other's needs and desires." How can married couples fulfill each other's needs and desires when there are constant prolonged absences?

If there is prolonged absence, it should be maintained by good attention, good correspondence. 
outside Influences

Outside influences may sometimes be hurtful to conjugal love. We do not give what we do not have. Sometimes married couples, instead of going to a knowledgeable or family-oriented counselor, listen to people whose own marriages had ended in disaster, or to people who have no notion of how to handle marital difficulties.

Dr. Harriet Braiker, ${ }^{1}$ a practicing clinical psychologist in Los Angeles, states that there are seven deadly signs that can affect a marital relationship. Each sign refers to a persistent pattern of negative emotions that one might feel in response to one's partner or one's relationship. They are "deadly" signs because each is known to have psychological consequences. These signs are:

1. Helplessness

2. Anxiety

3. Hostility

4. Frustration

5. Cynicism

6. Loss of self-esteem

7. Hopelessness.

These deadly signs are emotional "buttons" that your partner pushes in you. Let us briefly consider each of the seven deadly signs.

${ }^{1}$ Braiker, 33. I am indebted to Harriet Braiker for many of the ideas expressed in this chapter. 
1. Helplessness refers to a sense of being out of control or of having lost control of yourself and of the problems in your relationship. This loss of control affects areas of your life beyond the relationship. These might include your ability to govern your personal health habits, such as eating or exercising. Or you might be prone to excessive emotional reactions such as outbursts of crying or fits of temper. Or your ability to focus and concentrate may be compromised.

A sense of helplessness makes you feel overwhelmed and unable to cope effectively with your problems. It produces the perception that you are trapped in a bad situation with few or no alternatives and that you are helpless to make yourself feel better. As a result, you might try to escape the overwhelming problems by sleeping excessively, using drugs, or using denial or avoidance strategies to shut out the sensation of drowning in your problems. Naturally, these ineffective and self-destructive ways of coping only make you feel deeply disappointed, perhaps even disgusted, with yourself. Your perception of your future is darkened and your view of life in general becomes sour. This combination of feelings results in depression.'

2. Anxiety comprises negative emotional responses that include insecurity, fear, and uncertainty, manifested 
as nervousness and tension. This often occurs when you are unable to predict or anticipate accurately either the behavior and feelings of your partner or the course of the relationship itself. Anxiety is fueled by fears of abandonment and reinforced by the malfunction of the relationship. When a relationship fails to provide the reassurance, stability, and commitment necessary to calm uncertainty, toxic anxiety results. If, for example, your partner cannot or will not make a commitment to your love relationship, assuming a commitment is desired--your anxiety can go sky high. ${ }^{1}$

Here is a case of anxiety. Analia is very anxious. Her husband is very demanding, exacting, and stingy. He exercises unilateral control over her and over the relationship. Her husband constantly criticizes or attacks her. She confessed to me that she would love to leave him, but because of their two daughters she refrained from doing so. The husband is very unpredictable and Analia told me she has developed symptoms of depression.

Chronic feelings of anxiety can damage your health in many ways. Protracted anxiety depresses the function of your immune system's natural killer cells designed to fight bacterial and viral infections. Tension and nervousness often produce headaches (including migraines), muscular and digestive disorders, exacerbations of painful arthritic

${ }^{1}$ Ibid. , 35. 
conditions, diabetes and other immune or autoimmune diseases, numerous skin disorders, and many other maladies. Anxiety is itself an emotional disorder and is closely related to depression. Protracted anxiety, caused by an unpredictable, unstable, or capricious relationship, triggers helplessness, loss of control, and clinical depression. ${ }^{1}$

3. Hostility typically takes the form of aggression, anger, rage, and irritability. A partner or relationship to which you respond with hostility on a frequent or chronic basis is bad for your health. If you are always ready for a fight, you may well be on your way to a heart attack. ${ }^{2}$ overt hostility involves raising your voice; saying hurtful, angry words to your partner; and blaming your partner for some wrong act.

Hostility also is a common reaction to frustration, exploitation, manipulation, jealousy, betrayal, and devaluation, and is likely to result when any of the deadly signs are present. As a consequence, excessive hostility over a sustained period of time results in a heightened risk of heart attack and other cardiovascular disease. ${ }^{3}$

4. Frustration occurs when the gratification or fulfillment of any of your significant psychological or

\footnotetext{
Ibid., 35-36.

I2Ibid., 37.

${ }^{3}$ Ibid.
} 
physical needs is obstructed. The longer your significant emotional needs remain unfulfilled, the more intense they will grow and the more toxic your frustration will become. Continued frustration of your significant needs invariably will generate feelings of anger, resentment, and, eventually, outrage. A "happy marriage" is one in which there is a relatively high degree of mutual need satisfaction. Conversely, an "unhappy marriage" has a high degree of mutual need frustration. If a relationship produces chronic, unmet emotional hungers, it will diminish the self-esteem of those involved, resulting in rejection, anger, and aggression. ${ }^{1}$ Mature love always involves the dimension of responsibility and respect for the needs of others. ${ }^{2}$

Our needs are numerous. They include affection, attention, acceptance, approval, reassurance, and praise. Poor communication can be a major source of frustration--and eventual hostility in relationships. When communication breaks down, your ability to discuss and resolve your problems is impaired. As a result, your relationship may be plagued by repetitive cycles of conflict over the same issues, causing further feelings of helplessness and futility. Hostility leads back to frustration and a

\footnotetext{
${ }^{1}$ Howard J. Clinebell, Jr., Basic Types of Pastoral Counseling (Nashville: Abingdon Press, 1966), 98.

'Ibid. , 19 .
} 
dangerous cycle is established. With no expressive outlet, the internal build-up of frustration and anger can produce symptoms of depression and anxiety and numerous physical disorders. ${ }^{1}$

5. Cynicism, jealousy, mistrust, suspicion, and disdain are characteristic components of the cynical reaction style. Cynicism frequently occurs as a result of disillusioning and disappointing experiences with love. The nature of the love may be romantic, platonic, or familial. ${ }^{2}$

If you expect the worst from your partner, he or she may eventually give up trying to prove you wrong and consequently conform his or her behavior to your cynical expectations, making your worst fears come true. BY harboring cynical emotions and expectations, you may also set the stage for your own self-destructive, preemptive actions. This means that you might wind up doing the very behavior you fear or suspect in your partner before he or she does it to you. Thus, if you believe that your partner ultimately will abandon you, you might be the one to end the relationship, even though no real evidence exists to substantiate your fears. Similarly, if you expect your partner to betray you through infidelity, you might become the one to stray, in a misguided attempt to protect your self-esteem.

${ }^{1}$ Braiker, 38-39.

${ }^{2}$ Ibid. 
Cynicism triggers depression, anxiety, and loss of self-esteem, and while cynicism and negativity will surely sicken your soul, they can do considerable damage to your physical health as well. Negative thinking fuels negative moods. The chronic psychological depression that results from cynicism reflects itself in the literal depression of your immune system, making you vulnerable to contagious and infectious illnesses, as well as to cancer. ${ }^{1}$

6. Loss of Self-Esteem includes feelings of diminished self-worth, inadequacy, negative self-image, reduced self-confidence, and deterioration of self-respect, with associated depression. Your self-esteem will also suffer as a result of participating in a relationship in which you feel unappreciated, unloved, unworthy, and mistreated. Several factors contribute to this loss.

First, the recognition that you have involved yourself in a relationship that is unhealthy will undermine your confidence in your judgment. Then, having realized your error, you may try to undo or correct it by attempting to change your partner or to fix the relationship. To the extent that your efforts yield little or no success, your self-esteem is likely to further deteriorate. ${ }^{2}$

Second, your self-esteem further erodes the longer you stay in a devaluing relationship. Consequently, your

\footnotetext{
${ }^{1}$ Ibid., 40.

I'Ibid., 41 .
} 
sense of helplessness increases and your self-esteem declines even more. With the progressive loss of selfconfidence, your motivation either to improve your situation or to muster the courage to leave is sabotaged.

When your partner simply cannot seem to make up his or her mind about you, the inevitable psychological message to your self-esteem is that, for whatever reasons, you are just not good enough. And yet we know that self-worth is deemed a core criterion of good mental health. ${ }^{1}$

7. Hopelessness comes in when your state of mind leads you to believe that your relationship and/or your life situation will never improve, or that it is impossible for you to feel better. This deadly attitude, known as the "giving up/given up" complex, has been isolated as the most consistent psychological precursor to a wide range of serious, often fatal illnesses. of course, when depression bottoms out into hopelessness, the risk of suicide is high. ${ }^{2}$ Giving up and allowing yourself feelings of despondency and hopelessness is the most dangerous choice you can make-- and it is a choice. When you choose to give up, chemicals transmitted from your brain through your body carry the same message. If your immune and cardiovascular

\footnotetext{
${ }^{1}$ Ibid.

${ }^{2}$ Ibid., 41-42.
} 
systems continue to receive that message, they may give up trying to keep you alive. ${ }^{1}$

It was mentioned earlier that the aim is to help couples become conscious of the hindrances and vicissitudes they may encounter in a marital covenant relationship. In my interaction with couples, I observe that most of the time they are not cognizant of the obstacles or problems that undermine their marital life.

Some of them, because of their christian upbringing, take for granted that their marital problems will someday disappear. And yet the problems persist. One lady said to me, "Pastor, I love the Lord. I do my very best to please my God. I am a good mother and I am a beautiful woman. Why can't my husband understand this and comply with my wishes?" During an interview I had with the lady's husband, the husband was accusing her of not understanding him enough. The point I wish to make here is this--human beings can face almost any external problem if all is well in their domestic affairs, if they are reasonably happy in their family ties, and are secure in the behavior pattern that bind husbands and wives, parents and children together in a warm bond of love and kinship.

Samuele Bacchiocchi, in The Marriage covenant lists the following elements as undermining the covenant love relationship.

${ }^{1}$ Ibia. , 42-43. 
1. Personality differences

2. Intellectual differences

3. Spiritual differences

4. Vocational differences

5. Role conflicts

6. Family crises

7. In-law difficulties

8. Sexual adjustments

9. Use of money. ${ }^{1}$

space does not permit me to elaborate on each of the differences.

I must admit that the hindrances that affect marital covenant love and those that I have tried to enumerate in this work are not exhaustive.

Whatever the cause, however, the solution lies in changing behavior. It takes goodwill, gentleness, and comprehension. It takes sacrificial love to effect change. It takes Christian growth and maturity. It takes concessions in order to make marital love work. It takes Christ in the home and in the heart to make it happen. "If any man be in christ, he is a new creation." "I can do all things through Christ who strengthens me" (Phil 4:13). Obviously, love and kindness are positive emotions; they are immensely healthy and, indeed, even healing. Love requires expression--verbally and nonverbally--in order to

\footnotetext{
${ }^{1}$ Bacchiocchi, 92-103.
} 
be adequately felt and communicated so that it can be nurtured and reciprocated.

Let us keep in mind that rebuilding a healthy relationship is an ongoing process. You must approach the solution to your relationship problems as a continuum rather than a black-or-white, all-or-nothing, quick-change event. This implies the need for commitment, patience, and endurance. It also requires that you learn to evaluate your relationship in relative terms. Relative to the way it was, is it getting better? Relative to the way it is now, how can it further improve? ${ }^{1}$

\section{Part Two: Techniques for Enhancing Marital Covenant Love}

Dr. Hans Selye, in his book Le stress sans Détresse, remarks that "whatever is the problem, we cannot face it but by one of two fundamental types of reaction: Actively, struggling with it, or positively, by running from it."2

Dr. M. Scott Peck echoes Selye's statement when he says that

life is a series of problems. Do we want to mourn about them or solve them? Problems are the cutting edge that distinguishes between success and failure. Problems call forth our courage and our wisdom; indeed they create our courage and our wisdom. It is only because of problems that we grow mentally and

\footnotetext{
${ }^{1}$ Braiker, 179 .

${ }^{2}$ Selye, 18, translation mine.
} 
spiritually. It is through the pain of confronting and resolving problems that we learn. ${ }^{1}$

It seems clear that simply telling one's partner to avoid any negative thought while trying to solve problems is unlikely to produce large gains in problem-solving success. The partner needs to know or learn some skills that will help him or her enhance their relationship.

Building love is a creative process, much more like painting a picture or playing a symphony than performing a mechanical function. Love will increase if both partners have or learn certain skills. Here are eleven techniques that can help build up marital love. These techniques are numerous and are not exhaustive, but the following ones are a good start.

1. Don't keep score.

2. Renew your marital commitment toward each other.

3. Take time alone to identify what each of you needs in order to feel loved.

4. Decide which of your desires are reasonable.

5. Understand that your needs and your partner's needs are not identical.

6. Take turns expressing and listening to each other's desires, attempting simply to understand, not to change them.

${ }^{1}$ Dr. M. Scott Peck, The Road Less Traveled (New York: Simon and Schuster, 1978), 15. 
7. Identify which desires each is willing and able to satisfy.

8. Be consistent and fair.

9. Learn to express love and affection verbally.

10. Build your partner's self-esteem by giving and receiving positive feedback.

11. Control your anger.

Remember, the success of the marital relationship depends, to a large extent, on the degree to which both partners are committed to making it happen. Now, let us take a closer look at each of the eleven techniques.

\section{Technigue 1. Recognize that love does not keep}

score. Sharing in love does not mean keeping a balance sheet of who is doing what and who is doing more. There will be times when we must give more than we get, but there will be other moments when we will need and receive more than we are able to give. Keeping score belongs in competitive sports, not in a mutually supportive relationship. True love is wanting to give to another person without any thought about who is getting the better of the deal. The idea that love involves some sort of quid pro quo is, at best, evidence of immaturity that needs to be outgrown. At worst, it is a distortion of love that turns two people into unhappy combatants vying for control.

of all the games that lovers play, this can be one of the most delicate. When the players are mature enough 
and care enough to stop keeping score, the contest is over. Love has declared another victory. ${ }^{1}$

of course, a certain amount of scorekeeping is bound to go on any time two people are involved. It can even be healthy, periodically, to step back from a relationship and take stock of the give and take for those who "love too much" and have a tendency to allow themselves to be exploited in relationships. This exercise is crucial, in fact. But scorekeeping is unhealthy and harmful to relationships when it is something a person does constantly, and always with the same results. The people we are referring to as scorekeepers are always keeping tabs and always feel they are giving more. ${ }^{2}$

Scorekeepers keep a running inventory of all the mean, insensitive things the other has done to them since the beginning of their relationship. No matter how long ago a scorekeeper was hurt or mistreated, he cannot let it be forgotten or at least forgiven. These individuals keep the ledger as a permanent part of the case they are building against the person who hurt or angered them. Even years after a particular wrong was committed, the scorekeeper

${ }^{1}$ Leo Buscaglia, Born for Love: Reflections on Love (USA: Random House, 1992), 25.

${ }^{2}$ Mary Ellen Donovan and William P. Ryan, Love Blocks: Breaking the Patterns that Undermine Relationships (New York: Penguin Group, 1989), 306. 
feels free to bring it up and throw it in the other person's face once again. ${ }^{1}$

Starved for love in their early years, scorekeepers go through life looking for someone to provide the emotional sustenance they did not receive in childhood. They bring to their adult relationships the hungry, needy child they've kept buried within, and it is with the sensibility of this inner child that they judge their current relationships. ${ }^{2}$

\section{Technique 2. Renew your marital commitment to love}

each other. Donovan and Ryan point out:

It is the nature of the human psyche to seek relationships that involve commitment and thus provide a sense of permanence and security. People need to know that no matter what happens, they have a home base they can always return to for love, acceptance and care. ${ }^{3}$

Although some people have a greater need for security than others, everyone has some need for a person or persons to "be there" for them and not just today or tomorrow, but also in the times ahead. ${ }^{4}$

The security of having a solid home base is what enables an individual to venture out into the world alone; without it, the world may seem more intimidating than exciting .

The word commitment is derived from the Latin committere, meaning "to join, connect, entrust." The verb

\footnotetext{
I'Ibid., 308.

${ }^{2}$ Ibid., 308-309.

${ }^{3}$ Ibid., 240 .

${ }^{4}$ Ibid.
} 


\section{1}

"to commit" means "to bind or obligate, as by a pledge." When a person makes a commitment to someone else, it is as if he has made a pledge that in essence says, "You can trust me, you can rely on me. I will be there for you in difficult times as well as in good times. The bond between us in important to me; I will do my best to keep it strong and make it last."

Technique 3. Take time alone to identify what each of you needs in order for you to feel loved. This technique requires that both partners grow to know themselves enough to understand what experiences are pleasurable to them. In fact, a delicate balance of the ability to give and the ability to receive is required. Many of us have experienced the frustration of trying unsuccessfully to satisfy a lover. often this happens because the lover has failed to identify what would give satisfaction. Naturally, then, the first step to love enhancement requires that both partners know themselves and what they expect from the relationship. ${ }^{1}$

The key to this technique is to identify very clearly how your partner can act to meet your need. Too often, needs are left either unstated or stated so generally that your partner remains at a loss to know just what to do in order to fulfill your requests. ${ }^{2}$ Be specific and polite.

'John Wright, La Survie Du Couple (Montreal, Quebec: Les Editions La Presse LTÉE, 1985), 76.

${ }^{2}$ Braiker, 193 . 
Ask yourself: "What could my partner do or say that would make me feel good? What could we do or say together that would make me feel happy?"

Focus on keeping your request positive and clear. Do not explain your need by criticizing what your partner has failed to do in the past. simply ask him or her to help fulfill your need now. And take turns. Then, tell your partner exactly what you would like him or her to do in order to meet your need.

List the desires you would like your partner to fulfill. When both of you have made requests, set a time limit for fulfillment of your promises.

Make an agreement to meet with each other at a particular time to discuss the results of the exercise. Use that opportunity to provide feedback to each other about how it felt to have your partner try to respond to your stated need.

Technique 4. Decide which of your own desires are reasonable. While you are alone, go through your list of wants. Mark an "R" beside those you feel are realistic wishes, an "M" beside those that might be worth discussing with your partner, and a "U" beside those you know are unrealistic. 1

The following example illustrates some of the problems involved in articulating needs.

\footnotetext{
${ }^{1}$ Wright, 79
} 
Jacqueline: "I asked Robert to do two things for me in order to make me feel happy:

(1) to accompany me at prayer meeting (2) to give me an allowance. I know he can do both for me if he wants to. Why should I make concessions all the time!"

Such demands are not unrealistic. Jacqueline's husband is home watching TV while prayer meeting goes on. He has a steady and good-paying job. He can afford to give her an allowance.

Technique 5. Accept that your needs and your partner's needs are not identical. You must be prepared to discover that your desires and your partner's are not identical.'

Jacqueline said, "I just want Robert to be close to me sometimes. I don't want to do anything else." Communication about each partner's list of desires will be productive, provided differences are seen as healthy rather than threatening to the relationship.

Remember, it takes mutual good will, comprehension, and tenderness for couples to resolve the unavoidable difficulties of life.

Technique 6. Take turns expressing and listening to each other's desires, attempting simply to understand, not to change them. ${ }^{2}$ Dr. Tom Rusk, in his book The Power of

\footnotetext{
${ }^{1}$ Ibid., 80.

${ }^{2}$ Ibid.
} 
Ethical Persuasion, ${ }^{1}$ outlines seven steps in exploring alternative approaches for problem-solving. I think these steps can be applied to technique 6 .

a. Establish that your immediate goal is mutual understanding, not problem-solving.

b. Elicit the other person's thoughts, feelings, and desires about the subject at hand.

c. Ask for the other person's help in

understanding him or her. Try not to defend or disagree.

d. Repeat the other person's position in your own words to show you understand.

e. Ask the other person to correct your understanding and keep restating his or her position.

f. Refer back to your position only to keep things going.

g. Repeat steps 1 through 6 until the other person unreservedly agrees that you understand his or her position.

Technique 7. Identify which desires each is willing and able to satisfy. ${ }^{2}$ once you have listened to each other's list of desires, try to sort the requests that your partner has made into four types: (a) those requests that

\footnotetext{
${ }^{1}$ Rusk, 70-73.

${ }^{2}$ Wright, 82 .
} 
you are willing and able to satisfy now; (b) desires that you would like to satisfy but feel you do not yet know how; (c) desires that you are able to address but do not want to; and (d) desires that are unrealistic.

Let us briefly consider the four classifications of requests.

a. Those requests that you are willing and able to satisfy now. Do not rush this step. You need to discuss your requests openly and calmly. Once you have listened to your partner's requests, identify those desires that you feel willing and able to satisfy. The serenity prayer is appropriate here: "God grant me the Serenity to accept the things I cannot change.. . The courage to change the things I can and wisdom to know the difference" (Attributed to Friedrich oetinger [1702-1782] and to Reinhold Niebuhr. The Serenity Prayer, 1934.)

b. Desires that you would like to satisfy but feel you do not know how. Certain requests will require that one or both partners make certain changes in their behavior. At this point, do not feel you need to agree on a plan that will teach the giving partner new skills required to satisfy. Both partners can simply appreciate the fact that an initial decision has been made to increase pleasant exchanges. ${ }^{1}$

'Ibid., 83. 
c. Desires that you are able to address but do not want to. Accept that your partner may not actually want to satisfy some of the things you ask, no matter how reasonable you may feel they are. A man confessed to me:

Pastor, my wife doesn't want me to support my mother financially. My mother carried me for 9 months, she cared for me from birth till I was able to take care of myself. My wife said I should listen to her. We need the money for ourselves. But I will not listen to her. ${ }^{1}$

Refusing to admit that one is reluctant to fulfill a partner's request may, in the long run, threaten the relationship, if it leads one or both to feel strong resentment, humiliation, anger, or anxiety. Be very aware of the demands you are making of your partner and be sensitive to his or her hesitation.

d. Desires that are unrealistic. " "I wish you were like Paul." "I wish you were like So-and-So." one lady said to me, "Pastor, I really don't know what to do to satisfy my partner. He thinks I should be like so-and-So."

I performed the wedding of a beautiful couple. Both started to attend church regularly each week. Both got baptized by immersion. Both decided to make christ central in their lives, knowing full well that without Him their marriage would not succeed. One day Ben decided to give up his faith. He asked his wife, claudia, to do the same.

\footnotetext{
${ }^{1}$ Ibid.

${ }^{2}$ Ibid.
} 
Claudia replied, "I can't put aside God in my life. since I. have found Jesus, I feel secure, I have hope, I feel different." Ben insisted, "If you listen to me, I will remain with you; if you don't, I am going to leave you." claudia replied, "Your request is unrealistic, illogical. In times like these, how can we make it through life's vicissitudes without Jesus in our home and in our lives?"

Ben left Claudia with two children, even though he visits them sometimes. But claudia remained steady in her Lord. As the one who studied with them, baptized both of them and performed their wedding, I can attest to the veracity of this story.

Technique 8. Be consistent and fair. Dr. Samuele Bacchiocchi says it nicely:

Couples who are committed to preserving their marriage covenants will not engage in "dirty fighting," hitting below the belt, or trying to win the argument. Paul alludes to this principle in Ephesians 4:25 where he says, "Therefore putting away falsehood, let everyone speak the truth with his neighbor, for we are members one of another..." Thus, a literal translation would read: Having put away falsehood, let everyone speak truthfully with his neighbor."

It is essential for a couple to commit themselves to an honest relationship so that when conflicts develop, they will not fall into the trap of lying to each other just to win the argument. ${ }^{2}$

\footnotetext{
${ }^{1}$ Bacchiocchi, 109.

${ }^{2}$ Ibid.
} 
Remember that your objective is to be more loving and affectionate throughout your life together.

One man said to me:

Pastor, I don't really understand my wife at all--I understand that she works five days a week. I agree that I must help her do domestic activities. But I find her unreasonable for wanting me to cook five days a week. Moreover, sometimes she does not know what to cook for the home, yet she would expect me to prepare a different dish every day.

As someone has put it, "If you have requested breakfast in bed, it would be unwise for one partner to prepare the breakfast six days each week."

The object of conflict should not be to find fault or to assess blame but to resolve problems. Marriage is not a competitive sport but a cooperative endeavor. When a problem occurs, the goal should not be to determine who is right and who is wrong, but to find a satisfactory solution. "The attitude of partners," as stephen Grunlan puts it, "should not be a win/lose approach; that is, every solution involving a winner and a loser. Rather, the attitude of partners should be a win/win approach. The couple faces the problem together and when a solution is found, they both win."1

Technique 9. Learn to express love and affection

verbally. Affectionate words, compliments, tokens of appreciation, and sharing positive feelings can be rich and satisfying ways to exchange affection. However, we must learn to express our feelings verbally. ${ }^{2}$

Leo Buscaglia, in his book Loving Each other, remarks that "the very measure of a good relationship is in how much it encourages optimal intellectual, emotional and

${ }^{1}$ Ibid.

${ }^{2}$ Wright, 80 . 
spiritual growth."1 In other words, when partners express love and affection the aim should be to elevate, to encourage, not to demoralize us or to endanger our human dignity. Here are a few verbal expressions of affection. a. Thank you for making this delicious supper even though you are tired.

b. I really appreciated your presence and caring during my hospitalization.

c. I think you and I, by God's grace, can surmount our difficulties.

d. I like it when you ask about my work. I feel you are interested.

Technique 10. Building your partner's self-esteem by giving and receiving positive feedback. When a relationship turns toxic, communication is often restricted to a negative feedback cycle. This means that you both may be mired in giving and receiving criticism or expressing anger, demands, bitterness, and even insults. Or perhaps you are simply ignoring each other. This technique is designed to break the negative feedback cycle and replace it with positiveness. ${ }^{2}$

This is what one writer had to say about the importance of self-esteem:

\footnotetext{
${ }^{1}$ Buscaglia, Loving Each Other, 15.

${ }^{2}$ Braiker, 194 .
} 
Life would no doubt be easier if we were all given a large dollop of self-esteem. If we generally feel good about ourselves, have a number of supportive people in our lives, and have some sense of purpose, we can overcome those intermittent feelings of isolation and emptiness. We learn to emphasize the successes and rewarding relationships we have. On the other hand, if the positive attributes of our lives are insufficient or lacking altogether, it becomes increasingly difficult to maintain appearances and to continue functioning in a responsible, productive, caring manner. It is very difficult to maintain a positive facade if underneath you are feeling empty or in pain. ${ }^{1}$

Samuel L. Deshay, M.D., and Bernice A. Deshay, R.N., propose the following techniques that can help bolster selfesteem.

a. Avoid discussions and situations that you know will lead to tension or irritation.

b. Take a casual, leisurely walk outdoors, away from all the hustle and bustle.

c. Lighten up--learn to laugh at yourself and at circumstances that normally upset you.

d. Try to look on the lighter side and associate with happy people.

e. Smile--even when you are alone.

f. Stay away from TV programs involving murders, crimes and violence. Instead, tune in to.good music. ${ }^{2}$

\footnotetext{
${ }^{1}$ Saul Levine, M.D., Rebuilding shattered Lives (Toronto, Canada: Key Porter Books, 1992), 3 .

${ }^{2}$ Samuel L. Deshay and Bernice A. Deshay, 15 Days to Lower Blood Pressure and Cholesterol (Pleasant View, TN: Upward Way, 1990), 96.
} 
Technique 11. Control your anger. A Chinese proverb states that "if you are patient in one moment of anger, you will escape a hundred days of sorrow."1 Why should a couple control their anger? Because marital satisfaction is lowest when a spouse uses emotional manipulative strategies on his or her partner. Moreover, "anger is the emotion that fuels violence. . . A society like ours, which urges the expression of anger, sanctions it, and makes movies about its virtues, is a violent society."2

There is no doubt about it, anger damages a marital covenant love relationship. According to Martin E. P. Seligman, anger has three components:

a. There is a thought, a very discrete and particular thought: "I am being trespassed against." often, events get out of hand so quickly that you will not be conscious of this thought. You may simply react--but the thought of trespass is lurking there nonetheless.

b. "There is a bodily reaction. Your sympathetic nervous system and your muscles mobilize for physical assault. Your muscles tense. Your blood pressure and heart rate skyrocket. Your digestive processes stop.

${ }^{1}$ Martin E. P. Seligman, What You Can Change and What You Can't (New York: Alfred A. Knopf, 1993), 127.

${ }^{2}$ Ibid. , 120 . 
Brain centers are triggered and your brain chemistry goes into an attack mode. All this is accompanied by subjective feelings of anger."1

c. "Third--and this is what the first two phases ready you for--you attack. Your attack is directed toward ending the trespass immediately. You lash out. What you are doing is nothing less than trying to wound or kill the trespasser. If you are well socialized, you will attack verbally, not physically; and if you are very well socialized, you will usually be able to control the attack somewhat. you will mute it, or suppress it, saving it for a more opportune moment. You might even turn the other cheek altogether."2

Can anger be controlled? Gary R. Collins remarks that it is unlikely that God would have instructed us to control anger if such control was impossible. Several Bible passages imply that control is possible and indicate how this can be done.

a. Anger must be acknowledged. Before we can put away our bitterness, wrath, anger, and malice, we must admit, at least to ourselves, that such feelings exist.

\footnotetext{
${ }^{1}$ Ibid.

${ }^{2}$ Ibid.
} 
b. Outbursts must be restrained. The man or woman of God thinks before acting. There must be a quiet weighing of issues instead of a gushing forth of sinful verbal explosives.

sometimes it is helpful to share one's burden of anger with a friend. It is always good to pour out one's feelings to God. The verbal activity often leads to new perspectives that reduce or dissipate anger before it is expressed inappropriately and allowed to harm others or damage relationships. ${ }^{2}$

According to Gal 5:19, 20, when we follow our own wrong inclinations (the flesh), our lives produce evil results. And listed in those "evil results" are hatred and fighting, jealousy and anger. Therefore, we can control anger

a. by being aware of our emotional reactions

b. by recognizing and admitting our emotions. (Admitting the feeling of anger does not mean that you have to act it out. "The evidence is clear: overt anger, contrary to popular belief, is bad for your heart." "Venting your anger is not good for your health. . . It may increase rather than decrease our

${ }^{1}$ Collins, Christian Counseling, 122.

${ }^{2}$ Ibid. , 122-123.

${ }^{3}$ Seligman, 125 . 


\section{4}

risk of coronary heart disease, and it can exacerbate depression." ")

c. by trying to understand why you have anger. What brought it about? Does my anger come from frustration? What type of frustration? What or who is the cause of my frustration? What positive solution can I think of?

The word of God says: "When you are angry do not sin. Do not let the sun go down while you are still angry" (Eph 4:26). Are you angry with your partner or someone else right now? What can you do to resolve it? Do not let the day end before you begin to work on mending your relationship.

${ }^{1}$ Ibid., 27. 


\section{CHAPTER 6 \\ COVENANT CHRISTIAN MATURITY}

\section{Introduction}

The objective of this chapter is to help couples understand that the ultimate end in marital covenant love is the attainment of completeness in Christ and that attaining maturity in covenant love is a long process that includes struggles. Sooner or later, every conscientious married couple must address the following questions: What concession(s) must I make if I want my partner and me to grow together in our relationship? What must I do in order to be the perfect partner in God's sight? For the sake of honesty, and for the sake of God, who has instituted marriage, these questions should not be evaded.

Do I want always to control my partner? or do I desire to encourage him or her? Am I building up my marital life? Or am I destroying it by the hardness of my heart? Do I recognize that my thoughts, feelings, and options do not always represent the truth? Am I actively building up my marital covenant love relationship? will I be hearing from the Author of marriage "Well done, good and faithful couple, enter into the joy of your Master?" 
Growing up requires a great deal of discipline... To grow up, you must work on areas of your life that reflect irresponsibility, foolish thinking, and immature behavior. This is true, whether you are 15 or $105 !^{\prime}$

In this chapter the following points are considered: The necessity of Christian maturity; Four essential elements of maturity; The characteristics of the spiritully mature person; The ladder of Christian maturity (Gal 5:22, 23); Four kinds of love: Eros, Phileo, Storge, Agape; Signs of maturity in ourselves and others. The seven priority guidelines for attaining covenant maturity are also studied. Finally, I focus briefly on the need to spend "Kairos time" with God and explain what that means.

\section{Part One: The Necessity of Christian Maturity}

The relationship between Christian maturity, on the one hand, and growth in a marital covenant love relationship, on the other, is a reciprocal one. For this reason, this final chapter is designed to assist couples by helping them to recognize how their christian experience fosters or inhibits their marriage relationship.

To understand the inseparability and reciprocity between our christian and marital growth experiences, let us consider our relationship with our Lord. The gospel accepts

${ }^{1}$ Swindoll, 169. 
us where we are, but it does not leave us there. The Christian life is to be one of dynamic growth in which "we are to grow up in every way into $\mathrm{Him}$ who is the Head, into Christ" (Eph 4:15). Paul also prayed that Christians will experience a relationship in which "your love may abound more and more, with knowledge and all discernment" (Phil 1:9) in order that we may know how to choose wisely in the important issues of life.

Calvin remarks: "The true growth of Christians is when they progress in knowledge and understanding and in love." The New Testament is growth-oriented and the inspired writers often rebuke Christians for not continuing to grow after accepting christ as their Savior.

Couples should also experience growth as they move through the changing cycles of life. Because our relationships are personal, the growth process is neither automatic nor always upward. For most marriages, there are ups and downs, plateaus of routineness, and valleys or despair, as we experience the normal joys and crises of family living.

The christian couple has the responsibility to grow into spiritual maturity. In Eph 4:12-15, gifts are given to godly men for the perfecting (maturing) of the saints.

\section{'John Calvin, New Testament Commentaries:} Galatians, Ephesians, Philippians and Colossians (Grand Rapids, MI: Wm. B. Eerdmans Publishing Company, 1979), 232. 
Till we all come into the unity of the faith, and of the knowledge of the son of God to mature manhood, to the measure of the stature of the fulness of christ; so that we may no longer be children tossed to and fro. . . . Rather, speaking the truth in love, we are to grow up in every way unto him who is the head, into christ.

Again Calvin comments:

Full manhood is in christ. For foolish men do not seek their perfection among us, that everything outside Christ is hurtful and destructive. The age of fullness means full or mature age. No mention is made of old age, for in this progress there is no place for it. Whatever grows old tends to decay; but the vigor of the spiritual life is continually growing.

In Greek thought and usage, "maturity" (teleios) often means "totality." It refers to the one who does the whole will of God. "Being whole" manifests itself in concrete behavior. Being undivided in relationship to God includes detatching oneself for that which separates us from God. 2

According to Rom 8:29, God has predestined each believer "to be conformed to the image of His son." It is the Christian's responsibility to live each day with the desire to be more like christ.

${ }^{1}$ Calvin, 182 .

${ }^{2}$ Gerhard Kittel and Gerhard Friedrich, Theological Dictionary of the New Testament, (1972), 73, 74 . 
Part Two: Four Essential Elements to Maturity

The process of spiritual growth requires four

elements analogous to those necessary for physical growth. I wish to illustrate these analogies through the following table:

Table 1

SPIRITUAL GROWTH ELEMENTS

Needs of Healthy Body

Food, water

Air

Exercise

Rest
Needs of Christian Life

Daily portion of God's word

Submission to the Holy

Spirit

Service to Christ

Worship before God's throne

Especially in this materialistic and religiously confused age, God seeks committed husbands and wives and godly families to worship Him. Christ said it a long time ago to the woman of Samaria:

The hour is coming, and now is, when the true worshippers will worship the Father in Spirit and in truth, for such the Father seeks to worship Him (John $4: 23$ ).

It is impossible to develop spiritual maturity without the presence of all of these factors. This means that the Christian couple must develop the practice of private devotions before the Lord, where the couple reads the Word, prays and worships the Triune God. This daily experience then motivates them to submit their body to the 
indwelling Holy spirit, to be used as an instrument in the service of Christ.

\section{Part Three: The Characteristics of the Spiritually Mature Person}

In his book Christian Counselling, Dr. Gary Collins writes: "The spiritually maturing Christian shows a desire to be like Christ, accompanied by some evidence of the fruits of the spirit in his or her life."1

Then Dr. Collins provides some guidelines for maturity. As one matures there is usually:

- A tendency to behave according to one's age (and not like someone older or younger).

- A capacity to assume responsibility.

- An ability to look at oneself and one's problems objectively.

- An ability to acknowledge but control emotions.

- An understanding of other people's feeling and a sensitive ability to respond to these emotions.

- A growing independence from the control of family and friends.

- A willingness to postpone immediate gratification so that greater satisfaction can be attained in the future.

- A responsible attitude towards sex.

- An ability to laugh and see the humorous side of life without tearing others down or resorting to criticism.

- A realistic and essentially positive self-image.

- An ability to make choices and live with the consequences of one's decisions. ${ }^{2}$

${ }^{1}$ Collins, Christian Counselling, 384.

${ }^{2}$ Ibid. , 364,385 . 
Part Four: The Pyramid of Christian Maturity

Gal 5:22, 23 constitutes a guideline for Christian maturity. In this passage we find the enumeration of the fruit of the spirit. "But the fruit of the spirit is love, joy, peace, patience, kindness, goodness, faithfulness, gentleness and self-control. Against such things there is no law."

The absence of these Christian graces in marital life impedes growth both in the home and in the church. In Gal 5:19-21, Paul condemns the whole nature of man as producing nothing but evil and worthless fruits. So he now tells us that all virtues, all good and well-regulated affections, proceed from the spirit, that is, from the grace of God and the renewed nature that we have from Christ. We can see from figure 1 that the apostle places love at the apex of the pyramid. Love is the first fruit of the spirit. Therefore, love, as the term is used in the Greek New Testament, is now examined briefly and, in turn, the other fruits of the spirit. 
LOVE

JOY

PEACE

PATIENCE

KINDNESS

GOODNESS

FAITHFULNESS

GENTLENESS

SELF-CONTROL

Figure 1. Growth Ladder

\section{Part Five: Four Kinds of Love}

Greeks describe four kinds of love: eros, phileo, agape, and storge. Agape is sacrificial love. This is a Godlike love. God loves with unconditional acceptance. The Apostle Paul wrote, "But God demonstrates His own love for us in this: while we were still sinners, christ died for us" (Rom 5:8). Storge is commitment. Marriage requires commitment in order to grow. "It is the watchword for a struggling, hurting, eroding marriage that seems destined to be locked up and closed forever."'

Love. Agape (sacrificial love) and storge (commitment) come into existence by choice, whereas eros (sexual) and phileo (friendship) are emotional in nature.

${ }^{1}$ Swindoll, 166. 
Eros is fueled by sexual desire and sexual attraction. This sexual drive is the force that preserves the species and ensures survival. Phileo is fueled by feelings of friendship and companionship. Both of these, along with agape and storge, are necessary for a happy healthy marriage. (See figure 2.)

AGAPE
STORGE
PHILEO
EROS
Figure 2. $\quad$ Kinds of love.

Joy means cheerfulness towards our fellow human beings and is the opposite of sadness.

Peace can be contrasted with quarrels and contentions.

Longsuffering or Patience gentleness of mind, which disposes us to take everything in good spirit and not be easily offended.

Gentleness and Kindness means mild of temper, calm, and quiet in disposition. A Christian is never to be morose or sullen, but ever-cheerful, thoughtful of others, and courteous. ${ }^{1}$

\footnotetext{
"Acts to Ephesians" SDA Bible commentary, ed. F. D. Nichol (Washington, DC: Review and Herald Pub. Assn.),
} $6: 982$. 
Goodness/Faithfulness is a quality of conduct that gives others reason for confidence in us. Faith is a mental attitude, faithfulness, or a pattern of conduct.

Meekness is the attitude of heart and mind and life that prepares the way for satisfaction. A "meek" spirit is, in the sight of God, of a great price (1 Pet 3:4). Meekness is often mentioned by New Testament writers as a cardinal Christian virtue. ${ }^{1}$

Self-Control or Temperance means moderation in all things and complete control over passion and appetite. Excesses of every kind are harmful.

\section{Part Six: Signs of Maturity in Ourselves and others}

In his book Theology and Therapy, Samuel Southhard has pointed out some signs of growth that we should look for in ourselves and others. ${ }^{2}$

1. "Spiritually maturing persons are in love with other people," just as God (is in love) with them and they are in love with God (1 Cor 12:31-13:13). This love gives power to discerning persons as they move through personal fantasies and cultural deception toward the true christ. By contrast, unloving "discernment" is characterized by a fascination with, and fear of, evil.

\footnotetext{
${ }^{1}$ Ibid.
}

${ }^{2}$ Samuel Southhard, Theology and Therapy (Dallas: Word Publishing, 1989), 255. 
2. "Persons of spiritual maturity expect the power to come from God rather than from themselves." In Southhard's words:

They seek no credit for their own methods of discernment, the quality of cures, or the recognition that they receive (1 Cor. 13:4). By contrast, persons who feel powerless are intoxicated with the appearance of power through momentary wonders ( 1 cor. 13:1-3).

3. Spiritually discerning persons are not only aware that power comes from beyond themselves, but also that they have no power to decide what God is going to do in the life of another person (John $3: 8$ ). They do not "lord it over" others. By contrast, power-hungry persons inappropriately pass judgment on others and seek to control. Like the leaders of the Corinthian church, these people assume that they have a superior, special gift of knowledge over others $(1 \operatorname{Cor} 2)$. But in the opinion of the Apostle Paul, they need a reminder about spiritual gifts ( 1 Cor $12: 1)$.

4. Spiritual persons know the relationship between human capacity to do good and evil. They identify with the strengths/weaknesses of other persons (Gal 6:1-3). They recognize that all persons are tempted and that each of us is to identify with the temptations of others, just as Jesus did (Heb $4: 15$ ).

In contrast, people who do not know or admit their natural longings, reject in their bodies the desires that God has placed in all of us. It was necessary for Paul to 


\section{6}

write to the spiritually repressed corinthians that a husband must practice sexual intimacy except when the couple agrees together to abstain for a period of time.

To reject this is to give occasion for satan to tempt them for their "incontinency" (1 Cor 7:5). By contrast, spiritually isolated persons are intoxicated with their own message and seek no approval from the body of Christ. Their feelings take precedence over apostolic faith.

5. Spiritually sensitive persons are aware of the uniqueness of God's movement in each person. They pay attention to personal characteristics and varied circumstances. Ambiguity and mystery are accepted and appreciated. In contrast, imprudent (unrealistic) converts are not "apt teachers." The present their own mountain-top experiences with God as the answer for everyone and fail to recognize that God speaks in a unique way to each person.

6. The spiritually mature are growing persons and their growth is within a Christian fellowship. The direction of the growth both in themselves and in those around them is steadily in the direction of compassion, patience, and courage. By contrast, those who are spiritually stunted believe they know all things and have no need to be taught of anyone (1 $\operatorname{cor} 4: 8-21)$. They are often in power conflicts with those who do not accept their 
judgments. Consequently, they are isolated from most believers in Christ.

7. The spiritually mature welcome correction and seek instruction (Pss $1: 2,12,13 ; 3: 12-16$ ). There is a spirit of graciousness in their ability to learn from others (Phil 1:15-17). In contrast, the spiritually insecure are moved only as they think, by God Himself, and then only when He shows them some "sign." Our Lord continually warned against seeking after such signs (Matt 12:38-42; Mark 13:4, 21ff.; Luke 17:20, 21).

8. The spiritually discerning look for the gifts of the spirit. What attitudes and actions follow from the work of the Holy spirit? Whenever someone asks about the presence of the spirit, the spiritually discerning will look for those personally identifiable characteristics mentioned in Gal 5:22ff. In contrast, those who dread authentic selfhood are fascinated with showy gifts and pay little attention to personal conduct or character. In fact, the Apostle Paul had to warn the corinthian church, which prided itself on spiritual gifts, that it tolerated gross sin in the membership and seemed unconcerned about this (1 cor 5:113). ${ }^{1}$

${ }^{1}$ I am indebted to samuel southhard for most of the ideas expressed in these eight points. See his Theology and Therapy, 225-258. 


\section{Part Seven: Seven Guidelines for Attaining Christian Maturity}

J. E. Adams poses the question, "Is it possible to have a Christ-centered home in today's world of trouble and sin?"1 I believe it is. How? The Christian couple has spiritual, intellectual, psychological, and other resources to help them to shine for christ and to have a truly happy, successful Christian home. I now offer seven such resources in the form of guidelines for attaining covenant maturity.

1. Trust in the Lord

Trusting in the name of the Lord and attachment to the Triune God is the first step to attaining christian maturity. Ellen $G$. White states:

Jesus rested upon the wisdom and strength of $\mathrm{His}$ Heavenly Father. He declares, "The Lord God will help me; therefore shall I not be confounded: - . and I know that I shall not be ashamed. - Behold, the Lord God will help me."

pointing to His own example He says to us, "who is among you that feareth the Lord . . that walketh in darkness, and hath no light? Let him trust in the name of the Lord, and stay upon his God" (Isa $50: 7-10) .^{2}$

Mrs. White continues:

So it may be with us. Christ's humanity was united with divinity. He was fitted for the conflict by the indwelling of the Holy spirit. And He came to make us partakers of the divine nature. So long as we are united in Him by faith,

${ }^{1}$ Jay E. Adams, Christian Living in the Home (Nutley, NJ: Presbyterian and Reformed Publishing Co., 1972), 9.

${ }^{2}$ Ellen G. White, The Desire of Ages (Mountain View, CA: Pacific Press, 1940), 123. 
sin has no more dominion over us. God reaches for the hand of faith in us to direct it to lay fast hold upon the divinity of christ, that we may attain to perfection of character.

The Christian couple has the promise of God's help to them in the vicissitudes of life today. "Never will I leave you; never will I forsake you" (Heb 13:5). In this same vein, Gene Getz writes:

There is only one perspective that will enable men and women to find answers to the perplexing problems facing them in their married and family life. It is the Biblical perspective. Apart from God's laws and principles as revealed in scripture, there is no safe way to determine ultimate and enduring answers. . . This new life in Christ not only gives meaning to individuals but in a special way provides purpose and resources for those who have become "one flesh." 2

\section{Living in the Present and Pressing on}

It is characteristic of a growing person to be present in the here and now rather than focusing on the past. It is also a mark of maturity to keep on moving. Life is like a bicycle. You must continue pedalling, in order to move forward. When you live in the present, you do your best to hear what others are saying and the way they are saying it. When you respond, you do so in a congruent way. John Bradshaw notes:

Congruence means that the content (the words we say) is consistent with the process (the way we say the words), our tone of voice, facial

\footnotetext{
${ }^{1}$ Ibid.

${ }^{2}$ Gene A. Getz, The christian Home in a changing World (Chicago: Moody Press, 1972), 9.
} 
expression, body posture, etc. Congruence allows for real contact. Mystified people tend to be either confused with others or in conflict with them. ${ }^{1}$

It is my contention that living in the present is vital in overcoming the conflicts of the past and striving for a better future. Here is the Apostle Paul's sound advice:

Not that I have already obtained this or am already perfect; but I press on to make it my own, because Christ Jesus has made me His own. . . . But one thing I do, forgetting what lies behind and striving forward to what lies ahead, I press on toward the goal for the prize of the upward call of God in Christ Jesus (Phil 3:12-14).

Paul does not question here the certainty of his salvation, as though he were still in suspense, but repeats what he had said before, that he still aimed at further progress, because he had not yet attained the end of his calling. The SDA Bible Commentary says of Paul's statement:

He knows that he who would win must keep the goal and the prize clearly in his mind. The contestant must not be turned aside by applause or insult, he must not relax, he must not stumble, he must not stop; he must continually press forward until the goal is gained. . .

The Greek word "skopos"--"a mark (on which the eye fixes)", "a goal"-- is related to the verb skopeo, "to spy," "to peer," to look into the distance."

Paul teaches by his own example that we must make progress. For the love of Christ to eclipse everything

'John Bradshaw, Creating Love: The Next Great stage of Growth (New York: Bantam Books, 1992), 127.

"Philippians," SDA Bible Commentary, 7:170. 
else, we must think of nothing else. Maturity in Christ must preoccupy our mind, body, and soul, and it must be the object of constant meditation. Therefore, Paul does one thing, and forgets all the former things. He expresses his assiduousness and excludes all diversions. When he says that he presses toward the mark, he means that he is not wandering from the way. He condemns the looking back, which can either destroy or impair zeal.

Spiritual resources, however, are a sine qua non for Christian effectiveness. When a Christian couple fails to utilize the provisions that God makes available for daily victorious living, they encounter many problems in the marriage. The solution to the couple's problems is not in our stars, to paraphrase Shakespeare, but in sacrificial love, mutual understanding, a christ-like condescension, a new commitment to make their marriage work, and above all, the submission of their collective will to the omnipotent, Omniscient God, allowing Him to do for them that which they cannot do for themselves. There is no other path to covenant Christian maturity.

\section{A Commitment to Loving God and Partner}

Love for God and for one's partner cannot happen unless one is willing to commit oneself to making it happen. And that love is a process that requires hard work and courage. It is true that all of Christ's strength is my strength, provided that I am willing to abide and remain in 
Him (John 15:4, 5). In other words, I must make a choice. I must choose to make christ central in my life.

\section{A Willingness to Face Reality}

If a couple wants to experience maturity in their marital relationship, they must realize that each must change and adapt to the other. We all have things to learn about relationships and most of us have habits that prevent our being happy with our partners. A case history is given by osborne of an overly possessive and domineering wife and a passive, non-communicative husband who were on the verge of divorce. The husband was shown that he needed to communicate his feelings to his wife. In turn, the wife had to learn to be less domineering. In the context of this behavioral change the marriage was saved. ${ }^{1}$

The chameleon is noted for its ability to change color, to blend in with its environment. This capacity is the creature's primary means of protection. A chameleon can be viewed in two ways. First we might despise it for its lack of character. After all, anything that changes that readily must not know what it wants to be. To change constantly to match one's environment could be seen as being

${ }^{1}$ Cecil Osborne, The Art of Understanding Your Mate (Grand Rapids: Zondervan Publishing House, 1970), 65. 
wishy-washy and spineless with no constant identity of one's . own. ${ }^{1}$

Conversely, we could see this four-footed creature as wise. It does not lose its identity as a chameleon when it switches from green to brown. It is only protecting itself from potential danger and harm. viewed positively, this lovely reptile becomes clever, creative, and competent. of course, the chameleon does not have the choice that husband and wife have regarding adaptation. The chameleon has no free will. ${ }^{2}$ Creating harmony in marriage necessitates adaptation, flexibility, and the willingness to change. To adapt means to aclimatize, naturalize, become accustomed to or familiar with. ${ }^{3}$

It is said that Socrates had a very cantankerous and peevish wife; but she was faithful. One day some friends of the philosopher said to him, "You are so wise, your wife is so bizarre, how come?" Socrates replied, "Now you understand why I am so wise." In other words, having such a difficult wife, socrates had to adapt to her in order to bring harmony in their marital life. It is a great quality to be able to adapt to one's partner, and to help him or her become all that God intended.

\footnotetext{
${ }^{1}$ Rainey and Rainey, 234.

${ }^{2}$ Ibid.

${ }^{3}$ Ibid. , 234, 235.
} 


\section{A Willingness to Admit Mistakes and Learn from}

Them

A growing person learns from his or her mistakes.

Janet Moursund points out:

The real mistake lies not in committing an error, but in failing to learn from it. Every mistake can be the signal for a new step toward therapeutic competence, if it is recognized, analyzed and used for growth. Don't be complacent about your mistakes. They are not good, and nobody likes to make them. However, don't magnify them out of proportion, either. Like rocks in a stream, they can be used to trip and fall over or as a bridge to a new and better place. ${ }^{1}$

Make sure that your decisions are not based on emotions and coercion but rather on truth, reason, and persuasion. Be prepared to change your mind when the evidence indicates that you should.

\section{A Willingness to Practice Self-Examination}

A spiritually mature person practices selfexamination. It was socrates who posed what is the philosopher's Magna Carta with his maxim: "The unexamined life is not worth living." In his turn, Paul wrote to the Corinthians: "Examine yourselves to see whether you are holding to your faith. Test yourselves" (2 Cor 13:5).

This is a plea for self-examination whether in marital life or in the church. For your own salvation and for the salvation of your partner and family, you have an obligation to do your share to help your marriage work, and

${ }^{1}$ Moursund, 213 . 
a further obligation to eradicate from your life, by God's grace, bad attitudes or habits in order to make your marriage a success. Do not refuse to invest the time and effort to improve the chances of making your marriage work. In your introspection, ask yourself the following questions:

a. "Is there anything I can do that would enhance my marital covenant love relationship?" This question invites us to look at what we really want to have and to change.

b. "What would I need to change in order to get what I want?" Do not make success contingent upon someone else's behavior, but you can determine how you are going to react.

c. "Are there any changes I could make in myself that would enhance my life?"

d. "What would I be willing to do to effect the change?"

e. "How can I be a hindrance to my own maturity?" The reason for such penetrating questions is to help ourselves bring clarity to our thinking and to the choices we make. It takes both courage and effort to look inside of ourselves. David wrote, "Search me, o God, and know my heart! Try me and know my thoughts! And see if there be any wicked way in me, and lead me in the way everlasting!" (Ps 139:23，24). 
Remember, self-examination should contain three things. We should, first of all, examine ourselves. We must remember what we have done, thought, or felt during the day. We examine what is false in ourselves. "What should I have done that I did not do?" In other words, we judge ourselves. Second, we meditate on God. We try to understand what is temporary and what is eternal, remembering that God's word abides. Therefore we must seek God first and His righteousness. Then we must try to anchor ourselves on $\mathrm{Him}$, allowing $\mathrm{His}$ spirit to invade us and fill us with the fruit of the spirit (see Gal 2:23, 23). Third, meditate on what is to be done now. Maybe what you have to do now is to confess your mistakes; to reconcile with your partner; to help someone who is in need; or to correct past mistakes.

\section{Spend Kairos Time With God}

There is a difference between kronos time and kairos time. Kronos time is clock time, like twenty-four hours in a day. Kairos time is quality time; the time a major decision is made; a time of intensity or change of direction. Why spend kairos time with God? Because the hour is solemn. Time is short. We shall soon no longer be able to labor on the work of our sanctification. There is not an instant to lose.

Kairos time with God can be a weapon against selfcenteredness. This is a kind of extrinsic religion, or 
turning to God but not away from self, where religion is used as a defense, where religion is used to sanction one's own lifestyle. By contrast, an intrinsic religious life will have this thirst and hunger for, and commitment to oneness with God and deep love for all others, including one's partner. Kairos time with God can be a tonic to help you practice what you preach; to walk as Jesus walked.

In Rom 13:11-14 Paul wrote:

Besides this, you know what hour it is, now it is full time for you to wake from sleep. For salvation is nearer to us now than we first believed. The night is far gone, and the day is at hand. Let us then cast off the works of darkness and put on the armor of light, let us conduct ourselves becomingly as in the day, not in revelling and drunkenness, not in debauchery and licentiousness, not in quarreling and jealousy, but put on the Lord Jesus Christ, and make no provision for the flesh, to gratify its desire (RSV) .

Here Paul is telling us about kairos time. The word we use for "time" or "knowing the time" does not refer to time in general but a time with distinct significance, a time charged with issues of practical moment. We are being alerted, in other words, to the fact that it is now "high time" to wake out of sleep. Hence it is the completion of the salvation process that is said to be nearer than when we first believed. ${ }^{1}$

${ }^{1}$ John Murray, The Epistle to the Romans (Grand Rapids, MI: William B. Eerdmans Publishing Co., 1977), 165. 
In using your kairos time with God to strengthen both your marriage and your Christian experience, you must ask these questions: Lord, what do you want me to do? What should I do? Then:

1. Wait on the Lord: "Lord, speak, your servant listens."

2. Pray to become like Jesus. Only the grace of God will enable you to love your wife as Christ loves the church.

3. Pray for purity of heart.

4. Pray for spousal commitment on your part. A spousal commitment includes some or all of the following decisions:

a. "To be committed to continuous personal growth and to support your partner's personal growth."

b. "To affirm your partner's strengths and be willing to be patient, to forgive, and negotiate conflict and differences."

c. "To make and keep agreements about relationship rules and roles."

d. "To stand by your partner in sickness and health, in bad times as well as good."1

${ }^{1}$ Bradshaw, 310 . 
5. Pray that you may be imbued with the Holy spirit so. that your decisions may be based on truth and reason rather than on emotions.

6. Pray for self-awareness. "Know thyself."

7. Pray that your whole humanity--that is, mind, soul, body--be saturated with the fruit of the spirit (Gal 2:22, 23)

8. Pray that you may demonstrate in your life the graces enumerated in 1 cor 13 .

9. Pray that you may always love and abide in Jesus. Why? Because "without Him you can do nothing" (John 15:4, 5) .

The pivotal need is to allow the Holy spirit to help you get rid of hindrances that undermine marital love relationships. As was the case with Apostle Paul, our ultimate success is found in the claim, "I can do all things through Christ who strengthens me" (Phil 4:13). 


\section{CHAPTER 7}

\section{DESCRIPTION OF SEMINARS}

\section{Seminar \#1}

The issues to discuss: stages of intimacy.

1. The Romantic/Honeymoon stage: During this

stage, the need for closeness is certainly met, and there is no fear of abandonment.

2. The Conflict/Power struggle stage: This stage can also be called: The separation and Individual stage. Each partner emphasizes his or her individual identity. They no longer see everything alike. Their likes and dislikes begin to clash. In this stage you see negative aspects of your partner that hit you at your core.

3. The Interdependence Stage: Interdependence means each person can live and function independently from the other and yet belong to and support each other. This mutuality of belonging provides endurance to the relationship. It is the real thing in being married, which also gives real freedom. The mutuality of giving and receiving promotes the stimulus for both the marriage themes.

${ }^{1}$ The seminar material was taken from the five sermon 
relationship and the marital partners to grow. According to " Lucy and William Hulme, where one partner is the giving one and the other one the receiving one, the relationship is stymied; and so are the partners. The interdependence needed for a healthy "one flesh" relationship is related by saint Paul to the sexual dimension of marriage. "The husband should fulfill his marital duty to his wife, and likewise the wife to her husband. The wife's body does not belong to her alone but to her husband. In the same way, the husband's body does not belong to him alone but also to his wife" ( 1 Cor $7: 3,4)$.

\section{The Full commitment stage: A truly genuine} relationship requires commitment. This is "the decision to care." It is the result of a promise made and kept. The partners stick together "in prosperity and adversity." The partners love unconditionally. It is this love that is the bonding agent in marriage; it holds in "joys and sorrows."

objective: To help couples grasp the fact that love and intimacy cannot be separated. Couples need to spend time nurturing and fostering this growth of intimacy. The purpose of marriage is seen in henosis, that one flesh relationship.

\section{Seminar \#2}

The issues to discuss: communication and listening.

1. Conflict Resolution: The ability to deal constructively with differences and conflicts. 
2. Listening skills: Listening skills include the . ability to set aside one's own feelings, positions, and perceptions in order to hear another person's differing feelings, positions, and perceptions.

Objective: To help couples send clear, direct messages without blaming or accusing.

\section{Seminar \#3}

The issue to discuss: forgiveness.

1. Couples are not perfect, therefore they can make mistakes. Hence the necessity to forgive each other.

2. The biblical meaning of forgiveness.

3. Six phases in the process of forgiveness.

objective: To help couples understand that forgiveness is a gift given to self, which releases an injured person from anger and resentment.

\section{Seminar \#4}

The issue to discuss: enhancement of the marriage relationship.

1. Techniques for enhancing marital covenant love.

2. Change can be effected with mutual goodwill, with understanding on the part of each partner.

3. Marital difficulties must be viewed as challenges not as failures.

objective: To help couples become conscious of hindrances that undermine the marital-covenant love 
relationship and to provide them with skills to deal with those hindrances.

\section{Seminar \#5}

The issue to discuss: Christian growth.

1. God expects Christian couples to grow into maturity.

2. Symptoms and avoidance of arrested development among Christian couples, and abandonment of childish attitudes that prevent marital satisfaction.

3. The ultimate end in marital covenant love is the attainment of completeness in christ.

Objective: To help couples understand that attaining mutual covenant love is a long process that includes much struggle. 
CHAPTER 8

EVALUATION, SUMMARY, CONCLUSIONS, AND RECOMMENDATIONS

\section{Evaluation}

What is the opinion of the participants in marital covenant love relationship? The first questionnaire was distributed at the beginning of seminar 1 . The second questionnaire was distributed at the end of seminar 5. The objective of questionnaire 1 was to help couples see themselves just as they are in their relationship. The objective of questionnaire 2 was to help couples see where they should be in their relationship and to see whether they have made some progress.

The objectives of the Seminars were to reinforce in couples the ideas that marriage is to be viewed as a life long; that marriage plays a profound role in our lives; that a good marital relationship is worth seeking; and that stability, loyalty, solidarity, and feelings of belonging and of sharing are all part of being married. 


\section{The Questionnaire Results}

The first questionnaire contained 10 questions. Each was intended to allow the respondent to express a feeling or an opinion based on actual experience.

Questionnaire 2 was divided into three parts. Part A contained 12 questions and Part B contained 4 questions. The objective of Part $A$ and $B$ was to assess the understanding of the couples on marital covenant love sermons and seminars, whereas Part $C$ was designed to see whether the couples have made some progress or intend to make progress.

- According to the testimonials collected, progress was made. Here is what one lady confessed to me: "Before attending the seminars. I used to ignore my marital problems. I used to practice denial. But now I don't do that any more. I really want my husband to be happy." Here is another testimonial: "Pastor, in your seminars you were describing the relationship that exists right now between my wife and me. If our problems are too big for you, please refer us to someone who can help us." The person added: "I have never said this to anyone before."

Therefore, I can truly say that the sermons and seminars on marital covenant love relationship are useful, and meet the needs of the people. The entire project is about change. The gospel that we are called to preach is essentially a call for change. 


\section{Summary}

It is becoming increasingly clear that the marital love relationship will have permanence only to the degree to which it satisfies the emotional, psychological, intellectual, spiritual, and physical needs of the partners. There is a hunger for intimacy in every marital relationship. Most couples split up because they failed to find the intimacy that they longed for; or because they could not endure the pain of living without the intimacy that they once felt they possessed. Someone has said that "it is not wise to kid oneself about the depth of a partner's reservoir for milk of human kindness." Marital intimacy is a tonic to the soul. Married couples must invest time and energy in the relationship if it is to grow. Good communication is the lifeline of successful intimacy, and is invariably the result of hard work of committed partners working in pairs.

Following the institution of marriage in Genesis is the story of the Fall. The Fall is a fall away from communion with God. The Creator's act of redeeming fallen humanity restores it to communion--to intimacy. All the barriers to closeness are removed through the divine initiative of forgiveness. We are loved, and forgiveness is an expression of this love. God's love is tangible. God has incarnated love, enfleshed it. Our marriage to God is a covenant based on reconciliation. Reconciliation is 
precisely what is needed in the hurts of marital intimacy. Covenant love can hold even when wounds are inflicted through carelessness, insensitivity, arrogance, and sometimes even retaliation. We can give to our human marriage the forgiveness we have received from God. The basis of our survival as husbands and wives is the grace of God, which is always present, always abounding. With this comes the hope of our calling--"For it is God who works in you to will and to act according to his good purpose" (Phil $2: 13)$. God is at work on our behalf, willing the growth of our marriage. What will keep us going during darker days in the belief that God is for our marriage.

\section{Conclusion}

This project was an attempt to find a response to the hindrances that undermine the marital covenant love relationship. To do so, I propose a practical approach that addresses the needs of the couples. Who does not need forgiveness and acceptance in today's society? Who does not long for intimacy or human tenderness? Who does not want to find a solution to marital conflicts? Who does not want to be authentic and honest in our relationship? Each of the subjects chosen touches on problems that currently exist and affect couples everywhere. In a nutshell, the project has but one purpose: to help couples to change for the better. For the sake of clarity, let me list the main conclusions: 
1. Marriage is a divine institution and it is for the happiness of men and women.

2. Marriage is a close, lifelong companionship; it is indissoluble, unbreakable.

3. Love and intimacy are indispensable ingredients of a good marriage.

4. Couples are human, therefore they can make mistakes in marriage. Hence the necessity of mutual forgiveness and acceptance.

5. In order for us to grow up in marriage, love must be unconditional and self-sacrificing.

6. We must learn techniques that can help us become better husbands and wives. But such techniques must be undergirded by the power of God.

7. A successful Christian family is the most convincing manifestation of the Christian marriage.

8. Marriage is from God; all is not lost in an estranged relationship. There is something on which one can rekindle a dead relationship.

\section{Recommendations}

The local church should be seen as a healing or caring community. The pastor's unique position offers both the authority and the opportunity to intervene and bring healing to many hurting and dysfunctional marriages. The marital covenant love relationship project is unique because it appeals to both church members and non-church members. 
However, based on my personal observation, the program should be conducted from Friday night to sunday afternoon. one participant commented thus: "This is fantastic, but it would be nice to have the married couples together in a specific place by themselves." This project can be a good witnessing tool, since it is designed to reach out to Christian and non-Christian couples. Healing, forgiveness, reconciliation, and acceptance must be seen as part of the mission of the church to reach out to those who are hurting. 
APPENDIX 1

LETTERS 
Ottawa East S.D.A. Church

194 Prince Albert st.

ottawa, Ontario $\mathrm{K} 1 \mathrm{~J} 9 \mathrm{M} 4$

January 8th, 1995

Dear

As you know, I am currently writing my project for the Doctor of Ministry Degree, at Andrew's University. In the course of my studies, I have become aware of what might be considered a need on the part of the married couples and those contemplating marriage in the church, and would like to be of service to our congregation in trying to meet that need.

The need to which I refer, involves the enhancement of marital happiness in our church.

I have made a special selection of your names because I feel, that you are the kind of couple who are deeply interested in personal Christian Growth, and that you would respond most positively to an opportunity for selfimprovement.

on Sabbath January 28, I shall begin to preach a series of five sermons on the theme "Marital covenant Iove Relationship". The last sermon in the series will be preached March 11. What I am inviting you to do is to share this preaching experience with me as a member of a critique 
and evaluative group.

Following each sermon there will be a fellowship meal. After the fellowship, this group will meet for two hours for Growth Seminar and evaluation.

I am asking you to help me become a better PastorCounselor. Questionnaires will be prepared for you to use in this evaluation.

The objective of these series on "Marital Covenant Love Relationship" is fourfold:

1. To communicate more effectively with your spouse.

2. To become more intimate in your relationship.

3. To enjoy your God-given gift of marriage.

4. To grow and mature in God together with your spouse. You and I can increase our understanding of "Marital Covenant Love Relationship."

Remember the dates! January 28, February $11 \& 18$, March $4 \& 11$.

Thank you so much for your willing cooperation and may God continue to bless you.

sincerely yours, 
APPENDIX 2

PRE-SEMINAR QUESTIONNAIRES 


\section{PRE-SEMINAR QUESTIONNAIRE \\ (CONFIDENTIAL)}

Information:

Name of Church

Name of Pastor

Age

Sex

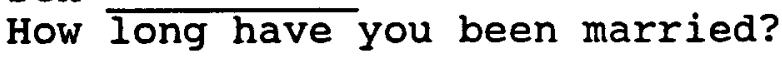

Read each statement and then circle the appropriate point that most closely describe your feelings.

$$
\begin{aligned}
& 1 \text { - Strongly Disagree } \\
& 2 \text { - Disagree } \\
& 3 \text { - Unknown } \\
& 4 \text { - Agree } \\
& 5 \text { - Strongly Agree }
\end{aligned}
$$

1. What I really want is a change in my partner's behavior.

2. I still love my partner though I don't appreciate his/her attitudes.

3. I listen to my partner's ideas, even if I don't agree.

4. I paraphrase or restate what my partner has said if it is not clear to me.

12345

5. I really do my best to understand my partner.

$\begin{array}{lllll}1 & 2 & 3 & 4 & 5\end{array}$

6. I change my mind when the evidence indicates that I should do so.

123345

7. I cannot experience marital satisfaction without changes in my partner's behavior.

123345

8. My influence is based on persuasion, reason and truth rather than emotion and coercion.

12345

9. I find it difficult to let my partner know something he/she does and says.

12345

10. I need to listen to my partner as he/she needs to listen to me. 
Table 1

Pre-Seminar Questionnaire Response Summary

1 = strongly disagree; 2 = disagree; 3 = unknown; 4 = agree;

5 = strongly agree

1. What I really want is a change in my partner's behavior.

2. I still love my partner though I don't appreciate his/her attitude.

3. I listen to my partner's ideas, even if I don't agree.

4. I paraphrase or relate what my partner have said if it is not clear to me.

5. I really do my best to understand my partner.

6. I change my mind when the evidence indicates that I should do so.

7. I can't experience marital satisfaction without changes in my partner's behavior.

8. My influence is based on persuasion, reason and truth rather than emotion and coercion.

9. I find it difficult to let my partner know something he/she does and says.

10. I need to listen to my partner as he/she needs to listen to me.

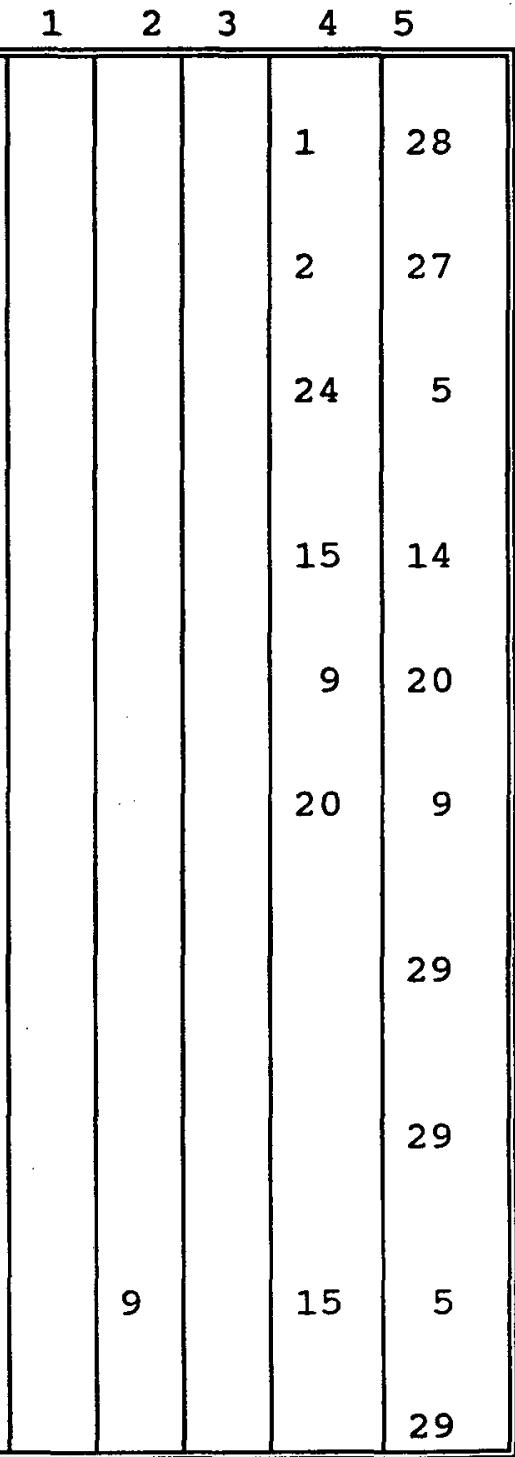


APPENDIX 3

POST-SEMINAR QUESTIONNAIRES 
POST-SEMINAR QUESTIONNAIRE

Information:

Name of Church

Name of Pastor

Age

Sex

How Iong have you been married?

How long have you been a church member?

A. Read each statement and then circle the appropriate point that most closely describes your feelings.

$$
\begin{aligned}
& 1 \text { - Strongly Disagree } \\
& 2 \text { - Disagree } \\
& 3 \text { - Unknown } \\
& 4 \text { - Agree } \\
& 5 \text { - Strongly Agree }
\end{aligned}
$$

1. This presentation on Marital Covenant Love helps me understand better my responsibility toward my partner.

2. I feel that God intends marriage to be permanent.

3. Intimacy and love are necessary ingredients of a durable marriage.

4. I feel that I get out of marriage what I put into it.

5. One's spouse must know that he or she is the most important person to the other person.

6. Without commitment the marriage cannot last.

7. Since no one is perfect, there is always a need to forgive.

8. If we forgive our spouse, our spouse is much more likely to forgive us.

12345

9. I am satisfied with my marriage now.

$\begin{array}{lllll}1 & 2 & 3 & 4 & 5\end{array}$

10. The sermons and seminars foster growth in marriage.

11. Communication skills are important in 
marital satisfaction.

12. This presentation is very useful.

B. Please circle the appropriate answer:

$$
\begin{aligned}
& \text { 1. Strongly Disagree } \\
& \text { 2. Disagree } \\
& \text { 3. Unknown } \\
& \text { 4. Agree } \\
& \text { 5. Strongly Agree }
\end{aligned}
$$

1. The Sermons and Seminars on "Covenant Love Relationship" have helped me to become selfconscious of some marital problems and how to go about solving them.

2. Marriages have their ups and downs, but God can use both the ups and downs for our marital growth.

3. The basis of our survival as marital partners is the Grace of God always present, always abounding.

4. Forgiveness is no substitute for changed behavior, but it is always the first step toward changed behavior. 


\section{Post-Seminar Questionnaire Response Summary}

1 = strongly disagree; 2 = disagree; 3 = unknown; $4=$ agree;

5 = strongly agree

1

1. This presentation on marital covenant love helps me understand better my responsibility toward my partner.

2. I feel that God intends marriage to be permanent.

3. Intimacy and love are necessary ingredients of a durable marriage.

4. I feel I get out of marriage what I put into it.

5. One's spouse must know that he or she is the most important person to the other person.

6. Without commitment the marriage cannot last.

7. Since no one is perfect, there is always a need to forgive.

8. If we forgive our spouse, our spouse is much more likely to forgive us.

9. I am satisfied with my marriage now.

10. The sermons and seminars foster growth in marriage.

11. Communication skills are important in marital satisfaction.

12. The presentation is very useful.

1 $\begin{array}{llll}2 & 3 & 4 & 5\end{array}$ 
Post-Seminar Questionnaire
Response Summary

B. Please circle the appropriate answer

1 = strongly disagree; 2 = disagree; 3 =unknown; 4 = agree;

5 = strongly agree

$\begin{array}{llllll}1 & 2 & 3 & 4 & 5\end{array}$

1. The sermons and seminars on "Covenant Love Relationships" have helped me become selfconscious of some marital problems and how to go about solving them.

2. Marriage have their ups and downs, but God can use both the ups and downs for our marital growth.

3. The basis of our survival as marital partners is the grace of God always present, always abounding.

4. Forgiveness is no substitute for changed behavior, but it is always the first step toward changed behavior.

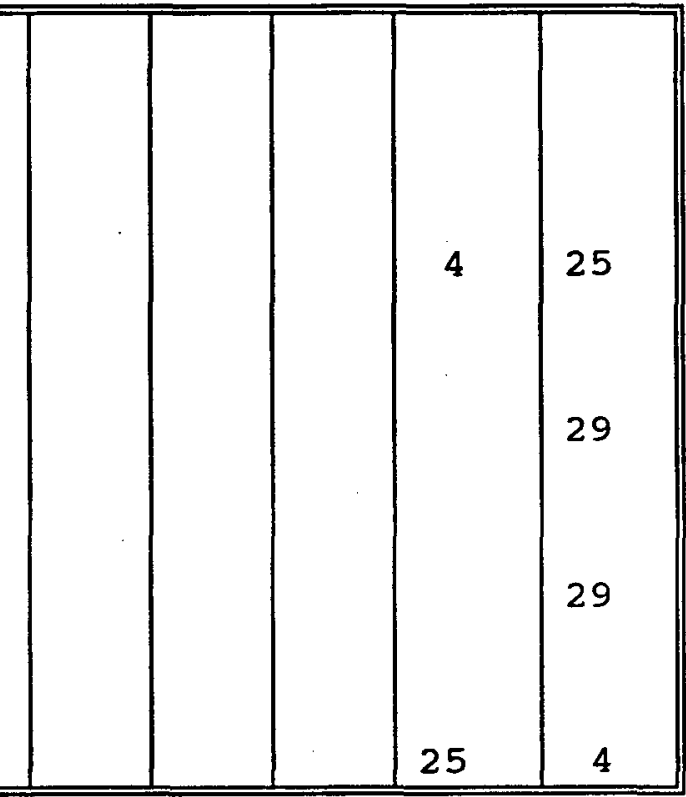


c. My progress in applying the techniques taught in Covenant Love Relationship Sermons and Seminars.

1 = strongly disagree; 2 = disagree; 3 = unknown; 4 = agree; 5 = strongly agree

I am doing this more I need to do this more I remain about the same

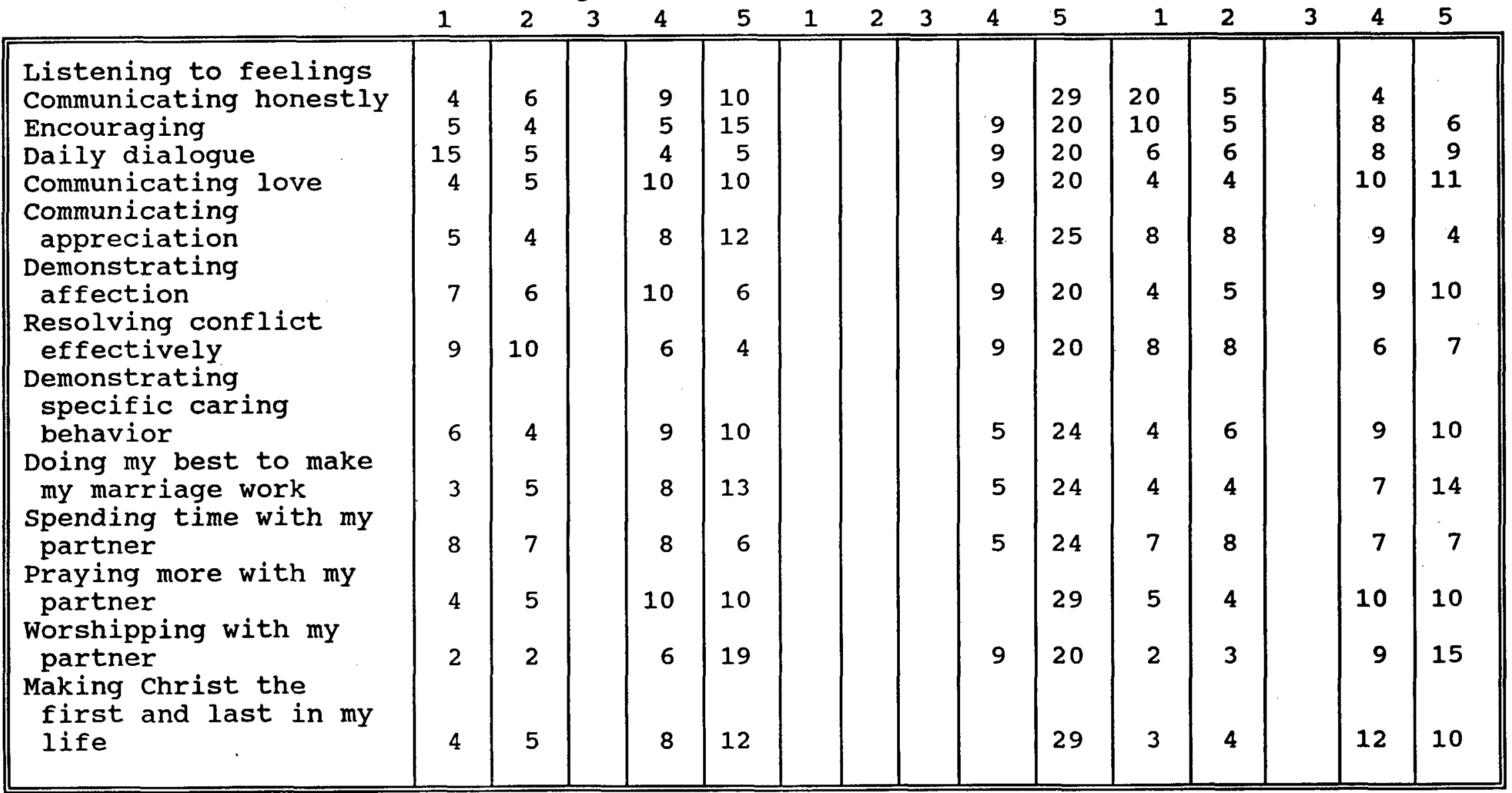


APPENDIX 4

EVALUATIONS 
FRAIK ULAY AUEUST CALPBET

\author{
P.0. Box 97, Sta. 'B', Ottawa, Ont., Canada K1P 6C3 \\ Tel. (613) 733-6023; Fax (613) 733-3702
}

EVALUATION OF SERHONS AND SEMINARS ON

MARITAL COVENANT RELATIONSHIP

bY FRANK A. CAMPBELL

(April 21, 1995)

\title{
A. INTRODUCTION
}

I was fortunate to listen to the sermons and to participate in the seminars which formed part of a recent series on "Marital Covenant Relationship". The series took place at the ottawa East Seventh-Day Adventist Church and all of the sessions were conducted by Pastor $V$. Jacques. I would like to make a few observations about the series in terms of its usefulness, practicality, and relevance to the church, and to close with a few general remarks.

\section{B. USEFUINESS}

The sessions were rich in information and ideas which could be implemented immediately. The usefulness of the actual sessions was reinforced by the handouts containing valuable information.

\section{PRACTICALITY}

The great value of both the sermons and the seminars was the way they dealt with practical issues and dispensed practical suggestions. The content was much more liberal than is normally associated with a religious environment and reflected a desire to reach out into the real world and touch on the real problems which people confront. Sensitivity was exercised in the way material on such topics as intimacy was presented during the midday services to take account of the different age groups present.

\section{RELEVANCE TO THE CHURCH}

If there is one thing the church needs, it is the sharing of skills and information dealing with family problems. Paramount among such problems are those associated with the marital relationship. As one of the two institutions created at Eden, marriage, like the Sabbath, needs to be regarded as an urgent and integral element in the theology and the mission of our church. Broken homes and unhappy families are, unfortunately, as much as part of the reality of our church as it is in any other group or category of people. 


\section{E. GENERAL REMARKS}

I was as much impressed with the enthusiasm, commitment and dedication by which the sessions were conducted as I was by the content. I would strongly suggest that such sessions - on this and related topics - be a staple of the program not only at ottawa East but at other Adventist churches as well. Moreover, I would suggest that we treat the sessions as an opportunity for outreach and use the mass media and other means to publicize the events.

Also, I would suggest that in future we place less emphasis on recruiting participants from among married couples. I would like to see former and future husbands and wives - yes, even the 16-year-old and 17-year-old - share this learning experience with us married folks. It is never too early, or too late, to learn these valuable lessons.

Even though the sessions were open to persons "planning to get married", I would go further, for two reasons. First, not every one planning to get married would be ready to advertise this fact to the church. Secondly, a seminar of this nature can help people, young and not so young, to decide in favour of marriage. One seminar participant said to me that the sessions helped to reduce her doubts about whether marriages can work. While there is much corrective work to be done, prevention is still better than cure.

Finally, I pray for God's richest blessings on Pastor Jacques as he brings this dimension firmly into an already valuable and important ministry. I am optimistic about his success. I wish him well.

\section{NOTE:}

Frank A. Campbell, a communications consultant and motivational speaker, holds a Master of Journalism (M.J.) degree from Carleton University, a Diploma in Mass Communication from the University of the West Indies and a Postgraduate Diploma in International Relations, also from the University of the West Indies. He is a former Ambassador of Guyana to Cuba and the current Youth Sabbath School Leader and Communications secretary at the ottawa East Seventh-Day Adventist Church. 


\section{AN EVALUATION ON THE SERMONS/SEMINARS PRESENTED BY \\ PASTOR JACQUES ON THE MARITAL COVENANT LOVE RELATIONSHIP}

1. The Ottawa East SDA Church in Ontario, Canada has been established for seven years and has a membership distribution of approximately 50\% single, 30\% married, and $20 \%$ divorce for members 20 years and older. The sermons and seminars were presented to the church primarily as a tool to resolve communication conflict and member generally gave the following responses when asked about the three month series of presentations:

a. The singles openly welcomed the presentations and felt that the lessons learned will undoubtedly prepare them very well for their future marriage relationships or just ordinary relationships in the classroom, work or at home;

b. The couples were excited that they were now equipped with useful tools to resolve conflicts in less painful and hurtful ways. When techniques presented are followed, couple find they can avoid hasty responses by following these techniques that facilitate understanding and discussions; and

c. The divorcees regretted that they did not have this opportunity years ago when they needed it most. They now feel blessed and will move forward in faith knowing full well they are now enriched in the knowledge that wherever God takes them they are better prepared to deal with communication conflicts.

Pastor Jacque's sermon/seminar on marital covenant love relationship worked because he effectively uses his own marriage relationship to illustrate many wonderful points.

2. The church on a whole benefitted immensely. We are now aware that the church family is not immune from the typical family squabbles. We have developed a better understanding of each other as men and women, with unique temperaments and idiosyncracies that are peculiar yet but very identifiable like fingerprints. From the course members can now isolate behaviour formed from cultivated tendencies and traits. We were encouraged to become skilful in seeking clarification to a misunderstanding rather than becoming overwhelmed and frustrated by the road blocks faulty communication generally creates for both the speaker and the listener.

3. I would recommend these sermons/seminars to any church. A congregation's ability to conduct outreach program is hampered greatly when it has to spend all its time in problem solving and discipline. The communication skills developed from attending the presentations will benefit thurch in the long run.

Erol Channer B. Eng., P. Eng. (Electronics and Systems Engineering)

Head Elder Ottawa East Church 
APPENDIX 5

SERMONS 


\section{NOTES FOR SERMON No. 1}

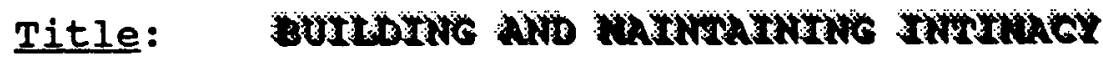

\section{Text: Genesis 2:24, 25:}

"For this reason a man will leave his his father and mother and be united to his wife, and they wil become one flesh. The man and his wife were both naked, and they felt no shame."

\section{Introduction}

Dear brothers and sisters, dear friends: My purpose this morning is not to consider the origin of marriage. For all of us know that marriage is a divine institution. It was God Himself who said that: "It is not good for the man to be alone. I will make a helper suitable for him." (Ge 2:18). Having made a helper suitable for Adam, the Lord brought Eve to Adam. (Ge 2:22). This was the institution of marriage. It was the actual marrying of Adam and Eve, the first marriage. But it was also the institution of marriage as a lasting ordinance for the human race.

Having said this, let me tell you exactly what I intend to do:

1. I intend to define intimacy and then

2. briefly we will consider the advantages of an intimate relationship.

3. I intend to tell you how to build and maintain 
intimacy in your marriage.

Judith $\mathrm{K}$. Balswick defines intimacy as "the process of coming to know and be known by another in a deep, caring way."

It involves self-disclosure and the ability to be naked and not ashamed in emotional, physical and psychological interaction. It entails an openness and shared vulnerability between spouses, which are dependent upon security established in a committed relationship." (Judith $\mathrm{K}$. Balswick, Toward a Practical Theology of Marital Sexuality, p. 285).

Balswick continues: "The bride and groom desire to know and be known in the most intimate ways, including sexual familiarity. They are pledged to grow together in an I - thou encounter of personal disclosure and vulnerability in their marital union."

1. Intimacy means to know and be known. As human beings we need closeness. The relationship of a man and a woman who are married is unique. Even those who are not quite satisfied with their marriage feel a strong sense of intimacy and a basic trust in each other, which they may notice only when one of them is under stress. A man confessed to me: "Pastor, I wish I had a sweet relationship with my wife."

2. Intimacy in your marital life offers you the safety valve needed to cope with life's problems. Clara P. Livsey, M.D. says this: "If a man is having a hard time on his job, to whom can he express his pain, his rage? To his boss, coworkers, friends, children? Most probably he will not. To do 
so may be inappropriate. If he does, he may lose face or his job; he may acquire a bad reputation. Only to his wife can he openly express his feelings. With her he does not have to be right or correct or cautious. No fear that she will fire him. If they have a workable marriage, she will listen and sympathize, be on this side." (Clara P. Livsey, The Marriage Maintenance Manual, How to Get Into it and How to Keep it Going, p. 4).

3. "Intimacy in marriage is worth seeking, among other reasons, because it is so protective to the spouses. People can be dissatisfied about their jobs, they may have health problems, or they may have problems with their children; yet they still will be able to cope if they have the strength provided by their relationship. Conversely, everything may be going well for a man or a woman, but if they have an unhappy marriage, all the other positive aspects of their lives careers, parenthood, health, seem lacking." (Ibid).

Two people can live in the same house and still come short of the kind of human companionship God intended. Fear, selfishness, and shame can keep them from entering into a close personal union. Even though married, they still remain alone, united only in part.

When McCall's magazine asked women the question: "What is most important to you now?" 61 percent of the 20,000 replied: "A feeling of being close to someone."

But there are several things to be understood about 
intimacy which are crucial to your achieving it. Intimacy is both deep and wide. It is deep in that it demands the sharing of one's inner self, allowing another to explore the inner caverns of self. Marital intimacy goes further than sexual exchanges; it involves an unveiling of one's very personal thought and feelings. (I will say more about intimacy in my seminar this afternoon.)

David, the psalmist, understood the meaning of intimacy when he wrote:

$$
\begin{aligned}
& \text { "O Lord, you have searched me } \\
& \text { and you know me. } \\
& \text { You know when I sit and when I rise; } \\
& \text { you perceive my thoughts from afar. } \\
& \text { you discern my going out and my Iying down; } \\
& \text { you are familiar with my ways." (Ps 139:1-3). }
\end{aligned}
$$

The Advantages of Intimacy

Intimacy brings satisfaction to the human spirit. Intimacy eases the anxiety of our estrangement and loneliness. We feel joined to another, and it feels warm and good. Here are the key benefits of a close relationship:

1. A feeling of relief and anticipation, knowing that the marriage brings stability, that no matter what problems lie ahead, the couple will not have to face them alone.

2. A strong bond of loyalty develops between the couple, helping them both to feel emotionally secure.

3. Intimacy reinforces each partner's self-esteem; since each 
knows the strengths and weaknesses of the other, there is no fear of abandonment.

4. The security of their commitment encourages the couple to grow. There is room for privacy. At the same time, however, there is is a sense of oneness.

5. The ability and the potential to find solutions that are suitable to them - even though they both know that problems are a part of life.

Building and Maintaining Marital Intimacy

What are some of the ingredients of an intimate marriage that distinguishes it from a distant relationship and from an unhealthy kind of closeness? What concrete steps can be taken to build and maintain true intimacy in marriage?

I propose the following four ingredients in building and maintaining intimacy in marriage: mutual respect; seeing differences as complementary rather than conflictual; affection and caring.

1. Mutual respect. Basic to all intimacy is an attitude of respect that both partners have for each other. While they are each unique and have many differences, they regard each other as persons with the same basic human dignity. They are sensitive to each other's needs and feelings as human beings. They realize that their partners deserve to be treated with the same kindness and sensitivity that they expect and desire for themselves.

Where there is mutual respect, there is no place for 
"putting down" one's partner, or for one person to dominate the other. There is less place for abusive language, gestures and "jokes" that leave one feeling "inferior".

2. See your diferences as complement. Two different beings becoming one means we should not fear asserting ourselves, too. Only when the two parts of the whole are truly what they were meant to be can the oneness be made possible. Each needs the other as a lock needs a key. Marriage is certainly the most difficult of all relationships, primarily because two people are thrown together and expected to relate in total harmony without serious disagreement, with common interests, goals and aspiration, for the rest of their lives. Too often dissimilarities drive partners apart because one of them does not allow the other to be himself or herself. one begins to dominate; the other feels threatened and crushed. Allow your differences to work for, not against you. 3. Demonstrate affection. External manifestations of affection have an important place in building and maintaining intimacy. Affection is a sign of the tender attachment that exists between a husband and a wife, as well as an important means of nuturing that warmth and closeness. Manifestations of affection should not be limited to times of love making, but need to be a regular part of the couple's daily life together. Holding hands, hugging, and embracing, looking at each other with a tender look, etc.

4. Caring. Marital love must involve agape love as well, or 
the marriage can flounder. Agape, or Christian love, is as concerned about the needs and the feelings of the other person as about our own. It suggests unconditional acceptance, even though the actions of the other person may seem unaccptable at the time. Caring means to consider the impact that your words and actions are having on your spouse. It is the willingness to lighten the other's burdens to ease the struggles of existence, and to make the journey of life a happier, more pleasant experience.

Caring involves the ability to empathize with another person, to feel what she feels, to know what it is like to walk in the other's shoes. Caring enables us to make sacrifices for our partner, to be by each other's side and to be for one another a safeguard, a source of support, nurture and nurture.

In conclusion, let me say this. Marital intimacy is a lifelong process that involves commitment on the part of both wife and husband to share as much of themselves as possible with each other. Says Ellen G. White: "The members of the family do not all have the same stamp of character, and there will be frequent occasions for the exercise of patience and forbearance; but through love and self-discipline all may be bound together in the closest union." (Patriarchs and Prophets, p. 176). 


\section{NOTES FOR SERMON No. 2}

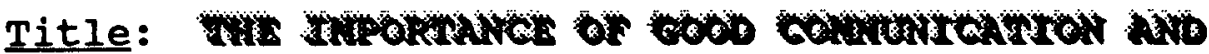

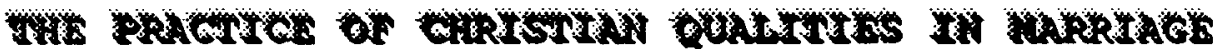

\section{Text: 1 Corinthians 13:4-8:}

"Love is patient, love is kind. It does not envy, it does not boast, it is not proud. It is not rude, it is not self-seeking, it is not easily angered, it keeps no record of wrongs. Love does not delight in evil but rejoices with the truth. It always protects, always trusts, always hopes, always perseveres. Love never fails. But where there are prophecies, they will cease; where there are tongues, they will be stilled; where there is knowledge, it will pass away."

Dear friends: The purpose of my sermon is twofold:

1) To show the importance of good communication in marriage, and

(2) to show that, in a marriage without the presence of those Christian graces enumerated in 1 Corinthians 13, communication skills alone will not keep the couple together.

Therefore, a happy marital life needs both a good communication system as well as the practice of Christian qualities. 


\section{THE IMPORTANCE OF GOOD COMMUNICATION}

The quality of marital life is greatly determined by how well the couple communicates and manages conflict. The first thing that a couple who is having problems will probably say is: "We don't communicate anymore." Even the business world is beginning to wake up to the importance of good interpersonel communications.

Judith and James sellner remark that: "If most couples communicated naturally, the rate of divorce, unhappiness, and violence in relationships would be drastically reduced. But most do not communicate naturally." (Loving for Life, p. 57).

Communication is important in the home as well as in the church. Gerhard Van Wyk observes that: "The God of the Bible is one who communicates and the Bible is God's book of communication." Genesis 3 presents God's dialogue with two people who are not only accusing one another but are hiding from God. (See Ge 3:10-12). "Throughout the history of God's people in the old Testament, we find God opening channels of communication. The New Testament emphasizes this point even more. With Pentecost, the spirit has made communication with God and between God's people possible. The power of the gospel brings about reconciliation and as result real communication between people is made possible. The gospel enables us to overcome every stumbling block and creatively communicate to every nation and kindred and tongue and people a present truth relevant to their existential needs." 
(Ministry, March 1995, p. 8).

Therefore, communication is vital to the survival of marriage and to the welfare of the church. Good communication is the foundation of relationship. As in a building, if the foundation is weak it must be repaired or the building will eventually fall down, no matter what you do to the upper structure. If the foundation is strong and well maintained, the structure can be blown apart but, you can start to rebuild on the same foundation the next day.

David and Vera Mace hold that an effective communication system is essential to the success of a marriage. Willingness to work at our marriage is not enough. "We must know what to work at, and how. And unless we are fully open to each other's thoughts and feelings, hopes and fears, we cannot clearly know what to work at, and the thrust of our efforts may be misplaced and wasted. We had a great deal to learn about couple communication." (Cited by A. Don Augsburger, Marriages that work, p. 92).

Effective communication

Married couples do not necessarily communicate effectively just because they live together. To learn to communicate more effectively and to understand clearly what our partner is communicating to us requires skills. We begin with the desire to establish better communication in our marriage and the attitude that our communication can be improved. Effective communication requires these skills: 
1. Become aware of your true feelings and thoughts and share your awareness.

2. Share feelings in an open caring way by stating what you feel without blaming.

3. Share meanings to be sure you understand each other.

4. Share intention.

5. Be emphatic. Hear, identify, and verbalize the other person's feelings.

6. Be responsible for your feelings.

7. Leave your partner free to be himself or herself. Encourage uniqueness.

our attitudes and beliefs can prevent our marriage relationship from improving. The following attitudes block communication and cause conflict or interfere with problem solving.

1. "I'm right." I don't need to hear what you have to say. I am just that way. You know how I am.

2. "It is your problem." Do not expect me to bail you out. Take care of it yourself. They are your relatives. If you had only listened to me in the first place, this would not have happened.

3. "You should anticipate my desires and feelings." By now you should know me. Why do we have to discuss it? can't you imagine what I am feeling?

4. "If we really love each other, why do we have to talk about this?" Love should conquer all. 
Hugh Allred and Thomas Graff have developed a systematic approach for improving communication between partners. They discribe communication as either level or vertical. When we practice level communication we seek to understand, negotiate, encourage, and reveal feelings. When we practice vertical communication, we draw attention to self, boss others, maintain or create distance and lor surrender. (S. Hugh Allred and Thomas T. Grapp, Couples' Handbook for Effective Communication, 1979).

The Purpose of Communication

The purpose of communication is to increase understanding between people or partners and to create a desire for continuing the exchange. The intention is to deepen interest, not create competition. Communication involves at least two parties: a sender and a receiver. Effective communication takes place when the receiver is able to "hear" the message and is able to respond to it.

A mixed message is one in which your words contradict your action or body language. Rebecca says: "No, Isaac I'm not angry", but then she keeps her distance from Isaac, in cold silence. She is sending a mixed message. She is not admitting her anger, but is showing it nevertheless. When you tell your partner you love herlhim, then proceed to ignore herlhis request that you spend more time talking together, you are sending mixed messages. "Good communication gives others the opportunity to decide for themselves. There is no 
emotional or intellectual coercion." (Gerhard Van Wyk, Ministry, March 1995, p. 8).

\section{Types of Communication}

One wife reported to her therapist: "My husband is an extremely fine conversationalist when he is at work and when we go out with a group of people, but if he is home alone with me he is the "silent type", and I do not know how much longer I can take it." Man is created a social being, and solitude is not good for him. Married couples must recognize, however, that companionship involves different types of communication. 1. There is the intellectual type. At this level of communication the husband or the wife recognizes the partner's need for some kind of intellectual interaction. He or she will enter into conversation with the partner and relate some of the day's events, dull and boring though they may seem to him or her, thus meeeting the partner's intellectual need to maintain an active and growing mind.

2. A second type of communication is the physical. There is a definite need to express love through physical relationship. Paul says it well in 1 Corinthians $7: 3-5$ :

The husband should fulfill his marital duty to his wife, and likewise the wife to her husband. The wife's body does not belong to her alone but also to her husband. In the same way, the husband's body does not belong to him alone but also to his wife. Do not deprive each other except by mutual 
consent and for a time, so that you may devote yourselves to prayer. Then come together again so that satan will not tempt you because of your lack of self-control.

Remember, marriage is a union of two people who become "one flesh". It involves mutual obligations and conjugal rights.

3. A third type of communication is the emotional. Someone said: "What is the use of going home after work! My wife has no respect for me. She tells me anything she wants to. There is constant fighting. I do not feel wanted and appreciated. I feel neglected, because the most important person in my life does not take time to understand me." If you want your partner to feel wanted and appreciated, you must feel his her emotional need. Maintain the house clean, cut grass, tell himlher that you will always love him/her, you must find great joy in one another's presence.

There are, of course other types of communication, but married couples must recognize these three as essentials to build a happy and satisfying marriage relationship.

\section{THE PRACTICE OF CHRISTIAN QUALITIES}

Love is the glue that keeps the marriage going. It is true that "the people perish for lack of knowledge." However, I believe that if Christian graces are not present in a marriage, communication skills will not be able to hold it. Peter says it well: "Love covers a multitude of sins." 
Peter $4: 8$ ).

When God commanded men to love their wives and told wives to be lovers of their husbands, He was speaking of Christ-like love. "Husbands love your wives, just as christ loved the church and gave Himself up for her." This kind of love is not romantic love. Romantic love is idealistic; Christ-like love is realistc. Romantic love is emotional; Christ-like love is basically active.

Says Ellen G. White: "True love is not a strong, fiery, impetuous passion. on the contrary, it is calm and deep in its nature. It looks beyond mere externals, and is attracted by qualiities alone. It is wise and discrimating and its devotion real and abiding." (Adventist Home, p. 51).

Ellen G. White continues: "A Christian must have a sanctified tenderness and love in which there is no impatience or fretfulness; the rude harsh manners must be softened by the grace of christ." (Ibid).

In 1 corinthians 13, Paul describes the ideal love. The agapic love. When you apply 1 Corinthians 13 to marriage, "you not only see where the rubber meets the road, you can smell it burning."

Love is patient. In other words, love is long suffering. "What is suffering? Some synonyms that come to mind at once are "pain", "tribulation", "sorrow", "anger". (Lewis B. Snedes, Love within Limits, p. 1). "When your spouse provokes you, you hang in there. You wait it out and then handle the 
dispute calmly at another time. You don't rush the person into growth or change, either. Like a gardener you watch the other mature and blossom - with patience." (Charles M. Sell, Achieving the Impossible: Intimate Marriage, p. 23). Agape is the love modeled by God in his relations with sinners, the love that drove Jesus to the cross. With agape we suffer long, but we suffer with hope. The model of longsuffering love is God Himself. God's love is his yes to a lost world. It is a redemptive yes, not merely an indifferent or indulgent one. It is a yes burning with desire for our salvation.

Love is kind. Kindness is the will to save. It is God's awesome power channeled into gentle heating. Kindness is love acting on persons. Kindness is the power that moves us to support and heal someone who offers nothing in return.

Kindness reaches out to help even when the other does not seem to merit it. Kindness is the power to move a selfcentered ego toward the weak, the ugly, the hurt, and to move that ego to invest itself in personal care with no expectation of reward. Kindness is love's readiness to enhance the life of another person. But it is more: it is the power to move close to another person in order to heal. Kindness is the power to bear another's burdens by feeling his pain in your own soul.

Love does not envy. There is no mental uneasiness over the other's success. We do not wish to have what belongs to someone else. We even pray for his success. 
Love does not boast, is not proud. It is very difficult to live with a proud person. "Boasting is a way of trying to look good when we suspect we are not good." "Boasting is our private advertising business, our little campaign to publicize an image of ourselves."

Love is not rude. "Rudness is putting people down in order to try to hold ourselves up." Love is never rude, because love is the power that moves us toward people for their good alone. Too often we reserve our politeness for people outside the family. We think we have the liberty to treat harshly those who are close to us.

Love is not self-seeking. While we can expect to get something out of marriage, this sacrificial attitude should dominate us. Love is the power that moves us to seek others. "The son of man came to seek and to save the lost." This being true, love appears to resist one of the deepest drives within any healthy being - the drive to discover and become one's own ideal self. Self-seeking is our humanistic duty. Remember Christ's word: "If anyone wants be My disciple, let him deny himself."

Love is not easily angered. Anger is not always wrong, but love does not lose control. Anger brings pain, an angry person wants to tear things apart. Unlike sadness, which is heavy and immobile, anger pushes us into attack. Agapic love is not irritable.

Love keeps no records of wrongs. Keeping score and 
getting even is destructive. Love is not resentful. Resentment is our memory of the painful, angry past. Resentment is deadly because its target is persons. Resentment depresses us, robs us of gratitude, sneaks into other relationships. Resentment damages our relations with our partners, our children, and our mutual friends.

Loves does not delight in evil but rejoices in the truth. Faultfinding is a damaging activity that love avoids. Love is forgiving, healing, accepting, and redeeming. But love rejoices only when evil is destroyed. Love knows the difference between falling into sin and programming it into one's life. "Love rejoices with the truth because love widens the scope of truth's lenses to include the whole person." (Smedes)

Love always protects, always trusts, always hopes, always perseveres. "Love covers a multitude of sins." ( 1 Peter $4: 8$ ). "Stego" is the Greek verb for covering up. Love keeps us quiet, tempering our tendency to say too much to quickly. Love has a fine sense for when to keep its mouth shut. Love hates a scandal. Scandal hurts people; and love hates everything that hurts people needlessly. Love covers up for the sake of healing. It keeps things quiet so that persons can be healed behind the scenes. (Lewis B. Smedes, Love within Limits, p. 86).

Loves always trusts. To say to your partner: "I believe in you", "I trust you", is one of the most suppositive things 
you can do for them.

Love always hopes. Sometime life's vicissitudes can bring discouragement. Depression makes you see a black sky in every direction. Then your partner says: "There is hope, I love and need you - tomorrow can be better than yesterday."

Love always perseveres. Love blends patience and courage in the face of all that hurts us and so enables to grow into a fuller person. Enduring means growing and expanding as persons under pressure. Endurance does not mean we don't seek help for our marital problems. We may have to take counseling to improve or reconcile our relationship. But there are times when all we can do is endure. Here is the greatest quality of love: love endures all things. Jesus endured the cross. Enduring may be painful. Christ's own passion and cross constitutes a model of christian endurance, (Heb 12:2), but His resurrection is a signal of victory through endurance. Salvation lies at the end of the tunnel. "The one who perseveres to the end, said Jesus, will be saved." (Mt 10:22; $24: 13)$.

Love never fails. Love abides. Love is the one power in this life that is self-generating. Love goes into eternity unchanged, for God is love. Love will never need to be transformed into something better.

Here is Pauls's concluding remark: "And now these three remain: faith, hope and love, but the greatest of these is love." 
As I stated in the beginning of my sermon, my purpose was twofold: (1) To encourage good communication in marriage and (2) to make you see the need to practice in your marriage the Christian qualities listed in 1 Corinthians 13. But how can this be done? It can be done through the power of God "who works in you to will and to act according to his good purpose." (Php 2:13). 


\section{NOTES FOR SERMON No. 3}

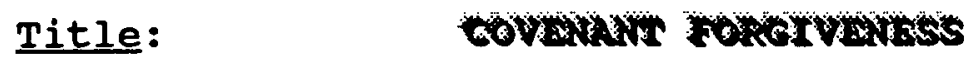

Texts: $\quad$ Matthew $6: 14,15$ :

"For if you forgive men when they sin against you, your heavenly Father will also forgive you. But if you do not forgive men their sins, your Father will not forgive your sins."

Ephesians 4:32:

"Be kind and compassionate to one another, forgiving each other, just as in Christ God forgave you."

Dear brothers and friends: In the Lord's prayer, we find the well-known phrase: "Forgive us our debts, as we also have forgiven our debtors." (Mt 6:12). Therefore, forgiveness clearly has two sides: we need to receive forgiveness and to extend forgiveness to others. Jesus makes it crystal clear: if we refuse to forgive others or our partners, God will refuse to forgive us. Why? "Because we are denying our common ground as sinners in need of God's forgiveness. It is easy to ask God for forgiveness, but difficult to grant it to others. Whenever we ask God to forgive us for sin, we should ask ourselves: "Have I forgiven the people who have wronged me?"

Life is filled with all kinds of personal hurts: white 
lies, broken promises, even physical injuries. They cannot simply be put aside or ignored. I think Beverly Flanigan is right when she writes: "Extreme emotions are the companions of intimate betrayals. Fury tainted with grief follows unforgivable injury of any kind, no matter what even causes it. To be betrayed by a stranger is one thing. To be morally wounded by one you have loved is quite another." (Beverly Flanigan, Forgiving the Unforgivable, p. 29).

\section{What is Forgiveness?}

According to the Christian Counselor's Manual: "Forgiveness is a promise, a promise that you'll never bring it up to the other person, a promise that you'll never bring it up to anyone else, a promise you'll never bring it up to yourself." (The Journal of Biblical Counseling, vol. XII, number 2, winter 1994, p. 8).

"Forgiveness is a result of hope, a reorganization of thought, and a reconstruction of dreams. Once forgiving begins, dreams can be rebuilt. When forgiving is complete, meaning has been extracted from the worst of experience and used to create a new set of moral rules and a new interpretation of life's events." (Beverly Flanigan, p. 29).

"Forgiveness has nothing to do with forgetting the past, either. A wounded person cannot, indeed, should not think that a fading memory can provide an expiation of the past. To forgive, one must remember the past, put it into perspective, and move beyond it. Without remembrance, no wound can be 
transcended." (Ibid.)

"The heart of covenant renewal is forgiveness. The story of Hosea makes that clear. The entire sacrificial system was God's provision for people who had broken the convenant. For wilful sin there was only the sheer mercy of God, which is not lacking" (R. Paul Stevens, Married for Good, p. 148).

Forgiveness is a costly matter. The death and resurrection of Jesus are the ultimate provision of God for covenant forgiveness and renewal. In marriage the only breach that cannot be healed is the permanent stepping out of the covenant by both parties. Forgiveness is the solvent of broken relationship within the covenant.

Sometimes we don't forgive because we think we cannot until our spouse repents. It is true that our spouse will not feel forgiven until there is repentance, but forgiveness is not dependent on repentance. Our kindness might in time lead our spouse to repentance as God's kindness does. Romans 2:4 states: "Do you show contempt for the riches of His kindness, tolerance and patience, not realizing that God's kindness leads you toward repentance?" It is our redemptive attitude that makes repentance easy. Redemptive love always uses patience and kindness. It seeks a resurrection.

Ron and Karen Flowers remark that:

"Redemptive love can last because the forgiveness it entails makes this kind of renewal possible. First, it can bear another's wrongdoing without 
yielding to the natural desire for revenge. Such forgiveness almost always restores interest in the relationship and leads to a firmer bond. Second, redemptive love opens the door for new beginnings. It puts the past as far away as east is from west and faces the future with hope. Loving another person does not mean that we no longer remember past injuries and conflicts. But it does mean that we consciously choose not to dwell upon them, that instead we bring to mind our covenant and our forgiveness. It means that we look to the moment at hand with courage." (Ron and Karen Flowers, "How to Redeem a Marriage", Ministry, September 1986, p. 6).

\section{How to Forgive}

According to the Bible, forgiveness must come from the heart. Jesus concluded the parable of the unmerciful servant thus: "This is how my heavenly Father will treat each of you unless you forgive your brother from your heart." (Mt 18:35). "The pretense of forgiveness, motivated by circumstances or by ulterior objectives, may deceive the one to whom it is accorded, but not Him who looks on the heart." (1 Sa 16:7). sincere forgiveness is an important aspect of christian perfection." (Seventh-Day Adventist Bible Commentary, vol. 5, p. 450$)$.

True forgiveness entails forgetfulness of the injury, the 
curing of all resentment and bitterness, and the restoration of broken relationship. It means "sending away" or "pardoning" or "cancelling" or "remitting" or "covering" what has come between two persons whose relationship has been severed.

Therefore, (1) forgiveness must be specific; (2) it must be verbalized; (3) it must be heartfelt; (4) and it must be maintained. Forgiveness must be from the heart because it is a decision. It is an art of will, not a feeling. Therefore, it is important actually to say: "I forgive you." Forgiveness brings restoration. Following the institution of marriage in Genesis is the story of the Fall. The Fall is a fall away from the divine image - from communion into isolation, alienation, and loneliness. God's act of redeeming fallen humanity restores it to communion, to intimacy. This bonding is more than a verbal covenant of forgiveness. We are loved, and forgiveness is an expression of this love. God's love is tangible, symbolized by the tangible water of baptism. God becomes one of us in Christ to love us in a human way. God the source of Forgiveness

In a sermon on the story of the sinful woman who was criticized for anointing Jesus' feet with both a precious perfume and her tears, theologian Paul Tillich says: "The righteous too want forgiveness, but they believe they do not need much of it. And so their righteous action are warmed by very little love." (Paul Tillich, To whom Much is Forgiven, 
in the New Being - New York, Charles Scribner's Sons, 1955, p. 13).

Again, refering to the woman, Tillich said: "It is not the love of the woman that brings her forgiveness, but it is the forgiveness she has received that creates her love." (Ibid). Those who have received forgiveness are like this woman who anointed Jesus' feet in gratitude. They extend forgiveness with much affection. Do you want to be forgiven? Forgive others. God has given us the responsibility for our own souls.

Jesus shows the way

Jesus shows the way by word and example.

1. Word. God has forgiven us in Christ. (AC 13:38; Eph 1:7; Eph. 4:32). He described Himself as the one who has been sent for "the lost sheep." (Mk 2:17). He rebuked His disciples for their unforgiving spirit. (Lk 9:55). He gave practical instructions as to the steps to be taken to secure reconciliation, beginning with a dialogue to talk things over. (Mt $18: 15-17)$.

2. Example. He stood to be baptized with sinners. (Mt 3:1317).

He was always associated with sinners and was stigmatized as the friend of publicans and sinners. (Mt 11:19).

He dined with them. (Mt 9:10).

He was a friend to the publican Zacheus (Lk 
19:1-10) and Levi. (Mk 2:13-17).

He was a friend to Judas who betrayed Him. (Mt $26: 50)$.

He remitted sins. (Mt 9:1-8; Lk 7:36-50).

He absolved Mary Magdalene (Lk 7:48) and the paralytic. (Mt 9:6).

He pardoned the cripple at the pool. (Jn $5: 14)$.

He forgave the adulterous woman. (Jn 8:11). He acquitted the disciples who deserted Him. On the cross, He asked the Father to forgive His enemies. (Lk 23:34).

He forgave the good criminal. (Lk 23:39-43). He gave his life and shed his blood to expiate sins.

He entrusted to his disciples the mission of proclaiming forgiveness. (Lk 24:27; AC 5:31; $10: 43 ; 13: 38)$.

Indeed, forgiveness brings peace and joy. It brings peace with oneself, peace with others and peace with God. Forgiveness in marriage makes growth possible. Forgiveness ends the destructive role of guilt. Forgiveness, as we have seen, allows the past to be past. Within the covenant of forgiveness we can let go of the past and become a new creation again. 


\section{NOTES FOR SERMON No. 4}

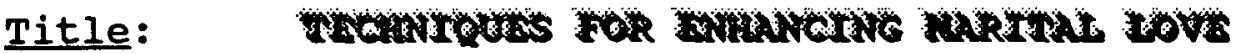

\section{Texts: John 15:5:}

I am the vine; you are the branches. If a man remains in me and $I$ in him, he will bear much fruit; apart from me you can do nothing."

Philippians $4: 13:$

"I can do every thing through him who gives me strength."

1. Jesus, using the vine metaphor, expanded its scope to all and individualized its application. In adapting it to the immediate situation, He stressed certain features.

The first was that there is a genuine stock. No fruit can be better than the vine that produces it. Jesus said: "I am the true vine." Unless the believer is vitally connected with Him, the quality of his fruitfulness will be unacceptable. There may be many branches, but if they are to bear the right kind of fruit, they must be a part of the real vine.

The second feature is that God, the Father, is the gardener. Success in raising any crop depends largely on the skill of the farmer or gardener. The relation of the believer to God is that of the vine to the owner of the vineyard. He tends it, waters it, and endeavors to protect it and cultivate it so that it will produce its maximum yield. 
2. Another emphasis is on pruning. Two aspects are noted: the removal of dead wood and the trimming of live wood so that its potential for fruit bearing will be improved. The verb translated "cut off" (aireo) means literally "to lift up" or "to take away"; the second, "trims clean" (kathaireo) a compound of the first, means "to cleanse" or "to purify." (The Expositor's Bible Commentary, vol. 9, John\Acts, p. 151).

Pruning is necessary for any vine. Dead wood is worse than fruitlessness, for dead wood can harbor disease and decay. The vine grower is concerned that the vine be healthy and productive. The caring process is a picture of the divine dealing with human life. God removes the dead wood from his church and disciplines the life of the believer so that it is directed into fruitful activity.

What does the symbolism of bearing and not bearing fruit mean? Spontaneously one tends to interpret the imagery in terms of good works and a virtuous way of life, but we must remember that John does not make the distinction that later Christian theologians would make between the life that comes from christ and the translation of that life into virtue. For John, love and keeping the commandments are so much a part of the life coming from faith that one who does not behave in a virtuous manner does not have life at all. Life is committed life. Therefore, a branch that does not bear fruit, is not simply a living, unproductive branch, but a dead branch. Some may find this interpretation harsh since it holds out no hope 
for the unproductive branches; yet in the gospel of John there is not much more room for an intermediate stage. There are only living and dead branches. In the atmosphere of the last supper, Judas may be thought of as a branch that did not bear fruit. He is now a tool of satan and belongs to the realm of darkness. (John 13:2, 27, 30).

What is the gardener's purpose for cleansing and trimming the branches that do bear fruit? The answer is obvious: so that the fruitful branches may bear more fruits.

Paul wrote to the Thessalonians: "May the Lord make your love increase and overflow for each other and for everyone else, just as ours does for you... You do love all the brothers throughout Macedonia, and we urge you, brothers, to do so more and more." ( 1 Th $3: 12 ; 4: 10)$.

In order to bear fruit we must remain in Jesus. That is why verses 4 and 5 of John 15 insist that in order to bear fruit one must remain in Jesus; all who remain in Jesus bear fruit, and no one else. The total dependence of the Christian upon Christ, which is the quintessence of John's thought, is expressed nowhere more eloquently than here.

Abide in me. "A continuous abiding in a living connection with Christ is essential for growth and fruitfulness. Occasional attention to matters of religion is not sufficient. Riding high on a wave of religious fervor one day, only to fall low into a period of neglect the next, does not promote spiritual strength. To abide in Christ means that 
the soul must be in daily, constant communion with HIm and must live His life. (Gal 2:20). It is not possible for one branch to depend upon another for its vitality; each must maintain its own personal relationship to the vine. Each member must be its own fruits." (Seventh-Day Adventist Bible Commentary, vol. 5, p. 1042).

Ellen G. White remarks: "Abiding in Christ means a constant receiving of $\mathrm{His}$ spirit, a life of unreserved surrender to His service. The channel of communication must be open continually between man and his God. As the branch constantly draws the sap from the living vine, so are we to cling to Jesus, and receive from Him by faith the strength and perfection of His own character." (The Desire of Ages, p. 676).

In order to bear fruit, we need to abide both in Jesus and in His word. We must abide in that word, it must put root down and and determine our entire life. Only then do we abide "in Him."

Christian husbands and wives who do not abide in Jesus and in Jesus' word may not be able to have a happy marital life at all. The branches cannot bear fruit of themselves, but receive their strength and sap from the vine. The believer is not a self-determined person, but one who is always receiving anew, who lays claim to nothing as his or her own accomplishment. And so neither does Jesus claim anything as His own achievement, as $\mathrm{He}$ is represented in the Fourth 
Gospel and throughout His earthly ministry. Listen to His own words:

\footnotetext{
"The one who sent Me is with Me. He has not left Me alone, for I always do what pleases Him." (John $8: 29)$.
}

Christ places Himself entirely in the service of the Father and renounces His own word. He gave Himself over entirely to what the Father has effected in Him. For that reason, His works were the works of the Father. "To empty the person so that the whole fulness of God can flow in is not something, of course, that can be acquired or forced by some technique of self-alienation. It is the mystery of love being enacted." Ernst Haenche, A Commentary on the Gospel of John, chapters 7-21, Fortress Press, Philadelphia, 1984, p. 131).

Now the question abounds, where is the connection between "abiding in Jesus", "bearing fruit", "abiding in Jesus' word" and techniques for enhancing marital love? of course, unless Christian couples abide in Jesus, or unless techniques are underguirded by an outside power, such techniques will avail nothing. Having said this, I would like to propose a number of techniques for enhancing marital love.

The word "to enhance" means to intensify, to increase in value or worth; to add to the effect. Says Ellen G. White: "All who are imbued with His spirit will love as He loved. The very principle that actuates christ will actuate them in all their dealing one with another." (The Desire of Ages, p. 
678). The above statement can be applied to a Christian couple as well. "Husbands love your wives as Christ loved the church." (Eph. 5:28). Such a love can be demonstrated if the Christian husband or wife is imbued with Christ's spirit. In other words, the Christian couple must abide in Jesus.

Technique No. 1 - Be totally honest with your partner, be authentic.

You recall Jesus' statement to the disciples at the foot washing: "And you are clean, though not every one of you." (Jhon 13:10). There He singled out Judas, who was consciously and deliberately planning to betray Him. Jesus did not equate "clean" with "perfect" but rather with sincere devotion that unites others to Him as branches are united to the vine. Judas was an example of branch that was cut off. The means by which pruning or cleaning is done is the word of God. It condemns sin; it condemns dishonesty; it inspires holiness; it fosters good behavior; it promotes growth. The word of God will empower and condition you to cast off bad habits that can undermine marital love relationship.

Technique No. 2 - Bear in mind that "apart from Christ you can do nothing."

Even the techniques that are being proposed here will not help you much. Continued production depends on constant union with the source of fruitfulness. The effectiveness of the believer depends on his receiving the constant flow of life from christ. 
Ellen G. White remarks: "Christ communicates the current of spiritual strength to every believer. So long as the soul is united to Christ, there is no danger that it will wither or decay." (The Desire of Ages, p. 679).

Technique No. 3 - I can surmount difficulties and meet challenges in my marriage through who gives $\underline{m}$ e

strength.

Fruit bearing is not only possible but certain if the branch remains in union with the vine. If the life of christ permeates the life of a christian couple, fruit will be inevitable. There will be better understanding and mutual respect.

Technique No. 4 - Make it a duty to pray and obey the word of the Lord.

obedience and prayer. To remain in christ and to allow His words to remain in oneself means a conscious acceptance of the authority of His word and a constant contact with Him by prayer. The prayer request must be related to a definite need and must be for an object Jesus Himself would desire. Remember, the proof of discipleship is fruit bearing: improved communication or better communication; more love for your partner. If you are obedient to God and pray earnestly to Him, your marital life will benefit.

"It is through the word that christ abides in His 
followers. This is the same vital union that is represented by eating His flesh and drinking His blood. The words of Christ are spirit and life. Receiving them, you receive the life of the vine. You live "by every word that proceedeth out the mouth of God." (Mt. 4:4). (Ellen G. White, The Desire of Ages, p. 677).

Honest, I would have liked to be able to mention some more techniques for enhancing marital love which binds couples together in an enriching way. But the four I have described are essential to a good marriage - (1) honesty or authenticity in my relationship; (2) recognizing that apart christ I can do nothing; (3) recognizing that Christ helps me surmount and meet marital challenges; (4) making it a duty to pray and obey the word of the Lord. I believe that these are four of the more basic elements in the covenant love relationship. 


\section{NOTES FOR SERMON No. 5}

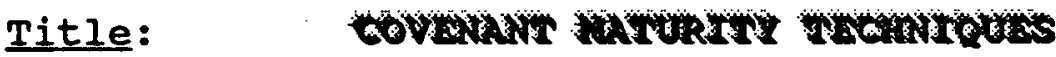

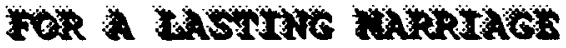

\section{Texts: Philippians 2:13:}

"For it is God who works in you to will and to act according to His good pleasure."

2 Corinthians 3:5:

"Not that we are competent of ourselves to claim anything as coming from us; our competence is from God."

Dear brothers and friends: Making our marriages last is harder now than ever before. The Christian home is in distress. Some marriages are clearly not going to last; others, you cannot tell. Some, of course, are making it: there are working, happy marriages all around us, couples successfully creating new balances, finding purpose and deep satisfaction in sharing their lives and coping with the realities at hand.

Each marriage, though, no matter how happy, is beset with problems of personality, survival, goals, the search for self, and the quest of our decade: "something more". "Something more" can be almost anything: success, money, peace, understanding, personal growth, even the very answer to human existence. 
"Something more" puts a lot of pressure on marriage." Times have changed, and it is not only in marriage but in every facet of our lives that we expect to have satisfaction. We, today, require more of our partners. Can we make our marriage last through all the changes in ourselves and in society?

You remember Christ's penetrating question: "When the Son of man comes, will He find faith on the earth?" (Mt 18:8). When christ comes shall the find committed married couples? Shall christ find faithful, God-fearing families on this earth? In this society where the demands are for instant gratification, instant intimacy, instant communication, instant everything, are we, I wonder, no longer aware of the flow and cycles of life, of our need for roots and continuity? Are we no longer able to accept the commitment of life together as growth? No longer able to last through the rough periods that inevitably come along in any marriage? The ultimate end in marital covenant love is the attainment of completeness in Christ. Mutual covenant love is a long process that includes struggles. The ever-increasing divorce rate even among Christians seems to indicate a lack of willingness to persevere to the end in marriage.

And yet, the desire for stability and security, the recognition of our needs for belonging and for being rooted in the constancy of another's affection are everywhere, running like a thread through everyone's story. Marriage can still 
provide all that and even more. Says Ellen G. White in the book "The Adventist Home", p. 105: "To gain a proper understanding of the marriage relationship is the work of a lifetime. Those who marry enter a school from which they are never in this life to be graduated."

Making the marriage last depends on many aspects of our relationship. We must be aware of the cycles of life and how they affect our shared existence. We must expect tension and conflict to arise from time to time; it is through resolving our conflicts and understanding the dynamism of tension that we grow. The discoveries we make about each other in our different phases of life together can make life interesting and exciting.

We can make the marriage last by restoring the romance in our lives. It is not the romance we see on television or in the movies, but the feeling that someone wants me, loves me, and appreciates me. It is the courting love "ahaba." "Ahaba" is the Hebrew love that makes us feel wanted. It comes from a root word for the love between $a$ man and a woman in marriage. "So, Jacob served seven years to get Rachel, but they seemed like only a few days to him because of this love (ahaba) for her. (Ge 29:20). This statement of pure human love is ahaba at its best - waiting, wooing and winning." ( $R$. Paul Stevens, Married for Good, p. 62).

For the sake of clarity I would like to propose the following techniques for a lasting marriage: 
1. Knowledge. Many married couples get into trouble because of lack of knowledge. The Bible is correct, "my people are destroyed from lack of knowledge." (Hos 4:6). Knowledge is easy to attain. Reading good Christian literature and attending courses or seminars are ways of increasing your knowledge. creating a successful relationship requires an understanding of the dynamics of relationships. But understanding the concepts is one thing; being able to translate that knowledge into effective behavior is another. once you have the knowledge, you then have to acquire the skills to put that knowledge into action.

2. skill. A skill is the ability to use your knowledge effectively. Two indispensable skills required for effective communication are talking clearly and listening. If you want to tell your partner that you love him or her or that you have a problem. with his or her behvior, you must convey that message clearly. If your partner has the ability and willingness to listen, he or she will understand you. There are some basic skills you must learn and practice on a daily basis 
if you want to have a successful, loving relationship. (See the chapter on covenant Communication as well the sermon on Good Communication and the practice of Christian Qualities in Marriage in the appendices).

3. Attitude. An attitude is how you feel, positively or negatively, about what you know. Attitudes are difficult to change because their source is emotional, not rational. Your attitudes are created out of your entire life's experience. A negative attitude is one that closes you from learning. You are not open to change. You may say: "I know enough", "when I want I will change", "I am not going to change my opinion." over time this leads to what we might call "psychosclorosis" hardening of the mind. Remember, God is willing to do for you that which you can't do for yourself. If you have an open and honest heart, the Holy spirit will help you get rid of all the bad habits in your life. Fear of being hurt physically, emotionally or spiritually underlies all negative attitudes. When parents fight to hurt each other and there is no forgiveness or resolution, a child hurts. The child forms a negative attitude in 
order to prevent hurting like that again. A positive attitude is keeping an open mind; it is essential to learning.

4. Behavior. A behavior is the external expression of your desire to have an effect on the world. Altering your behavior is much more dificult than changing your knowledge, or attitudes, or learning new skills. For example, the typical smoker knows that smoking is unhealthy, and most smokers have a positive attitude about quitting. Some smokers even take courses to develop the skills to quit, but they still smoke. You change your behavior only when you are motivated to do so - when you allow the spirit of the Living God to come into your heart, and to transform it. Motivation can be internal or external. Lasting, satisfying change in behavior occurs when you are internally motivated. External motivation (sometimes referred to as threat, force, punishment, or coercion) may be effective in the short run, but only internal motivation, or willingness, creates long-term behavioral change.

5 commitment. Basic to marriage is the kind of commitment we made to each other before God and witnesses. 
This commitment is a great wall of strength during the attacks of discouragement, difficulty, and doubts. Commitment helps pull the couples through times of temptation, tension and trial. "I committed myself to fidelity and to the permanence of marriage, with no thought of divorce as an option in case difficulty arose.

\section{Unselfish living.}

My wife and I find that the more we forget our own rights and demands and seek the good of the other, the happier we are. Marriage cannot grow without unselfish giving and living. To think of a marriage as a fiftyfifty proposition is not enough. Unselfish living means that we think of the other first, for it is in giving that we receive. In enriching the other, we find enrichment. When we unselfishly serve each other, we grow in stature, satisfaction, and self-fulfilment. But when we stop giving and living unselfishly, affection dries up and resentment results. When we become too concerned for self, we react and strike out; and relationships deteriorate. When we love each other, we make each other lovely; when we 
honor each other; we make each other honorable; and when we respect each other, we make each other respectable.

\section{Mutual openness.}

Openness builds trust which is basic to a happy marriage. Without trust, a relationship soon disintegrates and is destroyed. But mutual trust grows out of frank and courageous sharing of thoughts and feelings.

8. Mutual understanding.

Marriage is meaningful also to the extent we seek to understand each. It is possible for married couples to live side by side, in the same house, and still be strangers to what the other is thinking and feeling. This means that each partner should work hard to understand the particular needs of the other. They are not the same. One makes up for what the other lacks. When there is mutual openness, couples feel appreciated.

\section{A spiritual base.}

The closer the couple araws to God, the closer they are to each other. In order for the marriage to last, couples need a sense of shared destiny, a uniting together in a cause greater than themselves. Happiness in 
marriage, as well as in other areas, grows deep and binding when it is not life's first object. "Pursuit of happiness" is a selfdefeating activity. Commitment, joy, and happiness come not in seeking them, but when we lose ourselves in sharing them.

To make marriage last, we need God. Day by day we recognize His blessings in our lives. When we kneel in prayer we rise better prepared for life. When we give ourselves together in the cause of Christ's kingdom, we find our lives growing in greater oneness. (See A. Don Augsburger, Marriages that Work, pp. $57-64)$. 
APPENDIX 6

SEMINAR MATERIALS 


\section{Building and Maintaining Intimacy}

In a healthy marriage, to be united means to share a common commitment, a common purpose, and common goals. It means agreement on the central issues. Unity requires giving up some of myself for the sake of the relationship. I put my spouse ahead of my parents, my friends, my activities, and my children. My spouse does likewise. This is unity. 1

In order to maintain unity in our relationship, we must often sacrifice what we are. I should spend time with other loved ones and even leave time for myself, but not to the detriment of my marital relationship. My spouse should do likewise. ${ }^{2}$

${ }^{1}$ DeLoss D. Friedsen and Ruby M. Friedsen, Counseling and Marriage, vol. 19 (Dallas: Word Publishing, 1989), 133. ${ }^{2}$ Ibid. 
The more of yourself that you put into a relationship, the more love, satisfaction and joy you will get out of it. Men and women are born incomplete, and need each other to become whole. They are born with complementary qualities and characteristics. Each needs the other to fulfil his or her human destiny. Happy relationships go hand in hand with peace of mind, long life, health, happiness and abundance. Men and women with poor relationships, or no relationship at all, have more ill health and die younger than men and women who live happily together. ${ }^{1}$

Tracy provided evidence to show that divorced men die from heart disease, cancer, and strokes at double the rate of married men. The rate of all types of cancer is five times higher for divorced men and women, compared to their single counterparts. If for no other reason than your desire to live a long and happy life, you should be very serious about building and maintaining excellent relationships with the most important person in your life. ${ }^{2}$ one's ability to create love and intimacy is directly proportional to one's skill and willingness to deal effectively with conflict and anger. It is easy to love and feel close when things are going well, but your mutual respect and goodwill is tested in times of antagonism or disappointment. ${ }^{3}$

${ }^{1}$ Brian Tracy, Maximum Achievment (New York: Simon and Schuster, 1993), 286.

${ }^{2}$ Ibid. , 286.

${ }^{3}$ Judith A. Sellner and James G. Sellner, Loving for Life (North Vancouver: Self-Counsel Press, 1991), 102. 
The ability and willingness to resolve conflicts successfully are among the most important social skills you can possess. These skills alone will help you gain selfconfidence and the respect of people around you.'

Strategies for resolving conflicts may be classified into nine basic types:
(1) flight
(2) diversion
(3) fighting
(4) compromise
(5) "smooth"
(6) withdrawal
(7) confrontation
(8) seeking help
(9) constructiveness

${ }^{1}$ Judith A. Sellner and James G. Sellner, Loving for Life (North Vancouver: Self-Counsel Press Ltd., 1991), 102. 


\title{
THE MARITAL PYRAMID
}

The Marital Pyramid illustrates well the steps to intimacy in a covenant love relationship.

\author{
Intimacy \\ Conflict Resolution \& Management \\ Communication Skills
}

Spiritual, Emotional \& Mental Health of Partner

The Marital Pyramid has four layers. The bottom or foundation layer is the spiritual/emotional/mental health of the partner. This has a great bearing on the happiness of the marriage. No one has perfect emotional responses and attitudes. However, it is important to a successful marriage for both partners to be free of any major spiritual, mental, and emotional problems. ${ }^{1}$

The second part of the pyramid is communication skills. Communication techniques are provided in chapter 3. True intimacy cannot exist without effective communication.

The third layer is conflict management. Learning to solve problems is a sign of growth. The way one handles life's vicissitudes, in particular the way one handles marital conflict, shows what type of person one really is. Intimacy is at the top of the pyramid. It is also the hallmark of a good marriage. Trying to help couples

${ }^{1}$ Adapted from Friedsen and Friedsen, Counselling and Marriage, 19:56. 
achieve intimacy while there are major unresolved conflicts is unlikely to be effective. This does not mean that the marriage has to be conflict-free. However, when conflict arises, the couple's closeness must be able to help them deal with it constructively.

D. and M. Friedsen state that any major psychiatric disorder--depression, anxiety, phobia, manic-depression, illness, schizophrenia, or paranoia, and any significant personality disorder--asocial, avoidant, antisocial, passive-aggressive--can contaminate the higher levels of the pyramid. ${ }^{1}$ 
According to $\mathrm{Dr}$. Allen B. Weisse, the different types of personality disorders are readily recognizable. ${ }^{1}$ Dr. Weisse's descriptions of personality disorders follow.

The paranoid personality is characterized by longstanding suspicion and mistrust of others.

The schizoid personality is isolated and lonely, and uncomfortable with human contact.

Histrionic types are excitable, emotional, and flamboyant, but often superficial in their relationships.

Antisocial subjects are unable to conform to the norms of society and are often found among the criminal class.

Narcissistic personalities tend to focus on their own physical and personal attributes and problems to the exclusion of others.

Avoidant personalities are unable to interact with others for fear of rejection and are commonly labeled as having "inferiority complexes."

The dependent personality is a submissive individual who often burdens others with his personal indecision and is in constant need of approval and reassurance from others. The compulsive person is characterized by his or her inflexibility and perfectionism as well as indecisiveness.

'Allen B. Weisse, The Man's Guide to Good Health (Yonkers, NY: Consumer Report Books, 1991), 162, 163. Dr. Weisse is a practicing cardiologist and a Professor of Medicine at New Jersey Medical School in Newark. 
The passive-aggressive person is driven by an underlying aggression masked by subtle obstructionism, inefficiency, and resistance to change.

The sadistic personality delights in hurting others. The masochistic individual enjoys being hurt or abused.

Couples must be aware that deaths of family members and friends, personal illness, marital problems, difficulties on the job, financial insecurity, and problems with one's children all pose major threats to our sense of well-being--threats that we must all confront at one time or another in the course of our lives."

Individuals with personality disorders think of themselves as perfectly normal and rarely seek help for their problems. As a result, their patterns of behavior, well established by adolescence, usually persist throughout adulthood. For instance, the neurotic patient frequently continues to function in society--going on with his or her daily work and household tasks despite any distress caused by mental or emotional symptoms. ${ }^{1}$

The psychiatric disorders mentioned above, when manifested in a relationship, can, if they are brushed aside, undermine love and intimacy. Like athletes, couples must keep themselves in a state of physical and mental health if they want to experience optimum levels of marital satisfaction. However, in the final analysis, we sustain

'Ibid., 157. 
intimacy by choosing to give. Paul wrote to the Corinthians:

The husband should fulfil his marital duty to his wife, and likewise the wife to her husband. The wife's body does not belong to her alone, but also to her husband. In the same way, the husband's body does not belong to him alone, but also to his wife. Don't deprive each other except by mutual consent and for a time, so that you may devote yourselves to prayer. Then come together again so that satan will not tempt you because of your lack of self-control (1 Cor 7: 3-5).

Married couples have the responsibility to care for each other. Therefore Christian couples should have a high regard for their sex lives. The man must understand that a wife desperately needs tenderness, understanding, and love. To be able to give herself freely to him, she needs to talk about unresolved conflicts and have them solved before making love. ${ }^{1}$

${ }^{1} \mathrm{Jack}$ Mayhall and Carole Mayhall, Marriage Takes More Than Love (Colorado Springs: Navpress, 1978), 218. 
Building and maintaining intimacy constitute one of the best ways to create excitement in the covenant marital love relationship. DeLoss D. Friedsen points out: "The thoughts, the feelings, and the behaviors of people in intimate relationships are positive. Positive about the marriage, positive about their partners, and positive about themselves."1

Love and intimacy cannot be separated. They may not be equated, but they certainly go together. When partners are intimate, they are emotionally and physically close in a way that allows them to feel safe while being vulnerable.

\section{Stages of Intimacy}

One of the keys to building and maintaining a sucessful marital covenant love relationship lies in understanding that intimacy goes through four stages. They are: the romantic/honeymoon stage, the conflict/power struggle-stage, the interdepencence stage, and the full commitment stage.

The romantic/honeymoon stage

This is the wonderful stage of togetherness and oneness that most couples go through. In its pure form, the man and woman want to spend all their time together and seem

${ }^{1}$ Friedsen and Friedsen, Counselling and Marriage, 
to have similar tastes, feelings, and desires. In this stage they perceive each other as being incredibly alike. In this romantic or honeymoon stage, the need for closeness is met, and there is no fear of abandonment. ${ }^{1}$

This stage is wonderful; it is exciting. There is a strong feeling that you were made for each other or that you have found something that draws you together. This romantic/honeymoon stage is healthy and important. "However, there is something potentially destructive about this stage if it continues too long. After a while, comes the fear of being swallowed up by the other person." 2

The conflict/power struggle stage

This stage can also be called the separation and individuation stage. In this stage, the two persons emphasize individual identities. They no longer see everything alike. In fact, they may begin to emphasize their differences in taste, values, activities, parenting styles, and even religious convictions.

The conflict/power-struggle stage begins when you realize that your partner is not all he or she appeared to be. He does something you do not like. She disappoints or betrays you. You realize that some of your basic values run counter to his or hers. Your likes and dislikes begin to

\footnotetext{
${ }^{1}$ Friedsen and Friedsen.

${ }^{2}$ Friedsen and Friedsen.
} 
clash.1

Anger, silence, jealousy, yelling at one another, slamming doors, withholding sex, demanding sex, being "nice," feeling tired as soon as he walks in the door, and fighting over money are some of the symptoms of the powerstruggle stage. ${ }^{2}$

In this stage, each sees the negative aspects of the other partner that strike at the other's core. The honeymoon or romantic stage has faded. Power struggles arise when the husband tries to tell his wife how she "should" be, but is not, and she does the same to him.

In this stage, each person pulls away from the other (separation) and each one emphasizes his or her individual identity (individualization). Doctors Judith $A$. and James

G. Sellner remark:

This stage of relationship is inevitable and unavoidable. It's the stage at which couples separate, divorce, berate each other verbally or physically, and enter counseling. The problem is not that conflicts and power struggles occur in relationships; the problem is that we are not taught how to deal with them and move beyond them.

The interdependence stage

"Interdependence means each person can live and function independently of the other. The interdependence stage is the midpoint between the extremes of total

\footnotetext{
${ }^{1}$ Sellner and Sellner, 22.

${ }^{2}$ Ibid.
} 
togetherness and dependence or total separation and independence."1

This stage can also be called the realistic stage. To choose reality is to allow yourself to see the good, the bad, the ugly, and the beautiful sides of your partner. Out of this comes a feeling of safety based on knowing who your partner is. You are with a real person and each person has his/her strengths and weaknesses. You know that your partner can be sometimes "beast," sometimes "angel."

The full commitment stage

A truly loving relationship requires commitment. Marriage is a covenant. It is indissoluble. clinical philosopher Peter Koestenbaum calls it "the decision to care." All relationships go through trying times--economic or psychological crises, illness, deep disappointments, or betrayals. That is the nature of ethical love, what has been referred to as covenant love. It is the result of a promise made and kept. ${ }^{2}$

${ }^{1}$ Friedsen and Friedsen, 130.

${ }^{2}$ Sellner and sellner, 31. 
The people in our lives might be divided into three groups. Acquaintances are people whom we know only casually. Friends are closer. They are people who care for one another, spend time together, and have similar interests and viewpoints. Intimates have all the characteristics of friends, but they also share mutual concerns and personal struggles. ${ }^{1}$

In marriage; intimacy includes sexuality. Husband and wife should show understanding and experience a closeness, acceptance, loyalty, vulnerability, accountability, caring, empathy, and love that is not present in mere friendship.

Physical communication is the most intimate expression of a highly successful marriage. For too long, principles and information concerning sexual relationship have been presented outside of God's truth. The implication often is that God and sex are set against each other. On the contrary, God is for sex $!^{2}$

${ }^{1}$ Gary R. Collins, Christian Counselling (Dallas: Word Publishing, 1988), 189.

${ }^{2}$ Tim Timmones, Maximum Marriage (NJ: Fleming $\mathrm{H}$. Revell Company, 1976), 19 . 


\section{THE IMPORTANCE OF COVENANT COMMUNICATION}

J. A. Fritze, a Lutheran minister and clinical counselor, has said:

You can't know anyone unless you communicate with them. You cannot love anything you don't know. Therefore, the depth of love existing between husband and wife will largely depend on the amount and depth of their communication. ${ }^{1}$

Communication (verbal and non-verbal) is a process of sharing information with another person in such a way that he or she understands what you are saying. ${ }^{2}$ Communication experts tell us that there are six messages involved in the communication process:
1. What you mean to say
2. What you actually say
3. What the other person hears
4. What the other person thinks he hears
5. What the other person says about what you said
6. What you think the other person said about what you said. ${ }^{3}$

The basic, most important techniques that couples must possess to deal effectively with interpersonal problems are communication skills. Both partners must be willing and

1J. A. Fritze, quoted in Jack Mayhall and Carole Mayhall, Marriage Takes More Than Love (Colorado Springs: NavPress, 1986), 65.

${ }^{2}$ Ibid. , 66.

${ }^{3}$ Mayhall and Mayhall, 67. 
able to communicate. Regardless of how willing and skillful one's partner might be, the communication quality is impaired unless the other partner somehow matches this willingness and skill.1

Both partners must desire deep, personal communication in their marriage. They have to make this a mutual priority. If one partner desires intimate communication and the other is indifferent, there is the likelihood of an impasse. ${ }^{2}$ However, a kind, patient, understanding, empathetic, communicative partner can be an excellent teacher. Where there is a will, there is a way.

${ }^{1}$ Challon O'Hearn Roberts and William P. Roberts, Partners in Intimacy: Living Christian Marriage Today (New York: Pantist Press, 1988), 33.

${ }^{2}$ Ibid. 


\section{EFFECTIVE COMMUNICATION}

The first aspect of effective communicaton is the sending of a message. The three basic requirements for sending an effective message are to phrase the message so it may be understood, have credibility as a sender, and encourage feedback on how the message is affecting the receiver. 1

How can couples know when communication is working effectively and when it is not? Effective communication exists between persons when the receiver interprets the sender's message in the same way the sender intended it. If John tries to communicate to Jane that it is a wonderful day and he is feeling great by saying, "Hi," with a warm smile, and if Jane interprets John's "Hi" as meaning John thinks it is a beautiful day and he is feeling well, then effective communication has taken place. ${ }^{2}$

Challon $O^{\prime H e a r n}$ Roberts and William P. Roberts, in their book, Partners in Intimacy: Living Christian Marriage Today, declare: "If asked what is the most important thing a couple must do to work toward marital intimacy, the answer would have to be: Communicate! Communicate! Communicate!" ${ }^{3}$ strong families and happily married couples have

${ }^{1}$ David W. Johnson and Frank P. Johnson, Joining Together: Group theory and Group Skills (Englewood Cliffs, NJ: Prentice Hall, 1991), 161.

${ }^{2}$ Ibid. , 107.

${ }^{3}$ Roberts and Roberts, 30 . 
been found to practice good communication. They are good listeners, and they are skilled in expressing their thoughts, desires, and emotions to one another. ${ }^{1}$ Judson Swihart remarks:

strong families do not automatically have a good communication system. They have to desire it, work at it, re-evaluate it. Communication requires a constant watchful eye and large doses of nurturing. ${ }^{2}$

David and Vera Mace in their book, The Sacred Fire, state, "An effectively functioning communication system is first and foremost in a marital love relationship." ${ }^{3}$

${ }^{1}$ George A. Rekers, Counseling Families (Waco, TX: Word Books, 1988), 107.

${ }^{2}$ Ibid.

${ }^{3}$ David Mace and Vera Mace, The Sacred Fire: Christian Marriage Through The Years (Nashville: Abingdon Press, 1987), 


\section{CHARACTERISTICS OF GOOD COMMUNICATION}

Dr. Ketterman ${ }^{1}$ has identified seven characteristics of good communication:

1. Communicators must have open minds and must focus on the present. 2

2. Communicators make sure their intellects are not subservient to their emotions.

3. Communicators must resist the temptation to be judgmental or to condemn.

4. Communicators must learn to empathize with each other, while avoiding execessive sympathy or pity.

5. Communicators do best when they "listen with their hearts as well as their heads."

6. Communicators must remain focused on the goal of each transaction.

7. Communicators must be both assertive and gracious. ${ }^{3}$

David W. Johnson and Frank P. Johnson suggests eight

${ }^{1}$ See Rekers, 107.

${ }^{2} \mathrm{Dr}$. Samuele Bacchiocchi, The Marriage Covenant (Berrien Springs, Michigan, 1991), 112, echoes the same idea. Dr. Bacchiocchi recounts the story of a woman who complained to her friend that her husband became historical every time they had an argument. "Her friend corrected her by saying 'You mean he becomes hysterical'. 'No,' replied the woman, 'I mean historical. Whenever we have an argument, he brings up every related problem since we have been married.'"

'Jay E. Adams, The Christian Counselor's Manual (NJ: Phillpsburg Reform Publishing Co., 1973), 65. 
guidelines to bear in mind when sending a message. ${ }^{1}$

1. Clearly "own" your messages by using first person pronouns ("I" "MY"). Personal ownership includes clearly taking responsibility for the idea and feelings that one expresses.

2. Make your message complete and specific. Include all the information necessary for the receiver to understand the message.

3. Make your verbal and non-verbal message congruent. Do not say one thing with your voice and another with your actions or facial expressions.

4. Do not be afraid to repeat yourself. Sending the same message more than once and using more than one channel of communication (such as pictures and written messages as well as verbal and non-verbal cues) will help the receiver understand your message.

5. Ask for feedback. To communicate effectively you must be aware of how the receiver is interpreting and processing your messages.

6. Make the message appropriate to the receiver's frame of reference. You would need to present the same information differently to an expert in the field and to a novice, to a child and an adult, to your boss and a coworker.

'David W. Johnson and Frank P. Johnson, Joining Together: Group Theory and Group Skills, 110. 
7. Describe your feelings by name (I feel sad), by action (I feel like crying), or by figure of speech (I feel down in the dumps). Description will help communicate your feeling clearly and unambiguously.

8. Describe others' behavior without evaluating or interpreting. When reacting to the behavior of others, be sure to describe it ("you keep interrupting me") rather than evaluating it ("you are a rotten, self-centered egotist who won't listen to anyone else's ideas"). ${ }^{1}$

Another indispensible element in interpersonal communication is the credibility of the sender. One lady said to me, "Pastor, I can't trust my husband at all. He is not trustworthy. He doesn't keep his word." No amount of communication techniques can help this husband in his communication with his spouse until he first brings his own credibility as a communicator into a state of repair.

${ }^{1}$ See Johnson and Johnson, 110. 
Obstacles to Covenant Communication

In his book, The Power of Ethical Persuasion, ${ }^{1}$

Tom Rusk lists five barriers to human communication:

1. We all live in unique and private worlds of personal experience.

2. Nearly everyone is insecure to some extent. Thus, when we feel threatened, hurt, or angry, we tend to react with blame and self-defense rather than with attempts to improve communication.

3. Everyone has difficulty handling strong feelings and maintaining a dynamic balance between mind and heart.

4. Feelings are facts to the person experiencing them. Rejecting a person's feelings makes the person feel rejected as a whole.

5. We almost always perceive some kind of power imbalance in difficult communication, but we rarely discuss power openly.

${ }^{1}$ Tom Rusk, The Power of Ethical Persuasion (New York: Penguin Books, 1993), 9. 


\section{Three Hindrances to an Effective communication}

1. The attitude that there is no point in communicating or continuing a dialogue is very damaging. Suppose Lisa had said, "Dan wants to leave. It is up to him. I won't discuss it with him." It is almost certain that Dan would have gone.

2. A second hindrance to communication is the idea based on a take-it-or-leave-it attitude. It is not enough to emit without being received. To be listened to--as well as to listen--is therefore essential. One lady said to me, "My husband sees only himself all the time. He does not care about my feelings at all."

3. Communication must be consistent if it is to be persuasive. The words we utter must coincide with the acts we do. In 1 John 3:18 we read: "Dear children, let us not love with words or tongue but with actions and in truth." Contradictory messages are harmful to a good relationship. We must send clear messages and we must be reliable and credible. 


\section{TECHNIQUES FOR ENHANCING COVENANT COMMUNICATION}

Couples need basic communication skills to deal effectively with their marital problems. My personal experience affirms this. One of the first things said by a spouse having marital difficulties is, "My husband and I don't communicate," or "My wife does not know how to communicate." Communication skills are vital to lasting relationships.

There are four important elements in communicating:

1. The Sender and Receiver of the Message

In this discussion, the couple constitute the sender and receiver. An exchange does not take place unless one sends a message and the other receives it. According to Judith $A$. and James G. Sellner, the effectiveness of the exchange is determined by the physiological and psychological condition of the individuals as well as the perceived relationship between a couple. ${ }^{1}$

\section{Form of the Message}

A message can be conveyed verbally (in words) or non-verbally (in silence, or by action). A rigid posture can send as powerful a message as a few well-chosen words.

\section{Content}

The content of a message can do four things:

(a) It can convey information. "I took your car to the garage, it will be ready at 4 P.M." "I 
bought your favorite soap."

(b) A message can transmit a feeling. "I feel unhappy" (with no smile on the face) or "I love you" (followed by a warm hug).

(c) A message can convey the desire to have power or authority over the other. "You should," or "Do what I say."

(d) A message can make a statement about your values, prejudices, or beliefs. "What is the use of your religion?" "You only care about one thing."

\section{Intent}

Effective communication requires that you be aware of your intent. Are you entering into this exchange to create more understanding, love, and intimacy? or are you more interested in changing or controlling the other person, getting your own way, or making your partner feel guilty or silly? 


\section{Five Techniques for Exploring \\ Your Partner's Viewpoint}

\section{Establish that your immediate goal is mutual} understanding.

When you realize that a communication is in trouble, you may try to say, "Look, it feels to me like things are getting out of hand. Can we back up a little and first make sure we really understand each other?" or "I don't feel like we are getting anywhere with this problem. Can we put a hold on finding a practical solution for the moment and simply compare our points if view in greater detail? I'd be happy to let you expand on your position first."

\section{Elicit your partner's thoughts, feelings, and}

desires about the subject at hand.

You can begin by saying, "I have a problem and would appreciate your help" or "I need to be certain that I understand what you want to happen as a result of our meeting or discussion."

3. Ask for your partner's help in understanding him or her.

Try not to defend or disagree. You might say it this way, "I think I hear what you are saying, but I want to double check. Do you mean that? . . " or "since nobody is perfect, I might be quite wrong about what is going on, so I need you to explain. . ." "Maybe I'm jumping to conclusions, but to me what you are saying means that . . Exactly what do you mean? How does it feel to you? Am I 
getting it right?"

4. Repeat your partner's position in your own words to show you understand.

"Okay, I want to make sure that I've got this straight. You are saying that .. . Have I got that right? Is that correct?" or "It's important to me that I really understand. Let me see if I can put what you are saying into my own words" or "So what you are saying is . . ."

5. Ask your partner to correct your understanding and keep restating his or her position. Ways to say this might include, "Okay, I need to back up a little. What exactly did you mean when you said? . ." or "Sorry, I guess I am jumping to conclusions. Tell me a little bit more about. . . so I can get this straight." "Thank you for setting me right on this. Let me know whether I've got it now. The way I would describe your position is . . ."1

Remember the foregoing techniques are designed to help couples communicate and express their feelings in a more effective way. Poor communication undermines the marital love relationship. As one lady in a counseling session said to me, "My husband can't communicate. That explains the trouble."

'I am indebted to Dr. Tom Rusk for some of these techniques. For more detail, see The Power of Ethical Persuasion, 70-80. 


\section{WHAT IS FORGIVENESS?}

Quite simply, when you forgive, you give up your right to punish. Forgiveness is an act of the will, a deliberate choice, which means you will not retaliate although you may feel the other person has wronged you. True forgiveness does not throw your mate's failures back at him/her or use them to hurt him/her!

Pure and free forgiveness gives us something we often do not deserve. This is how God relates to His children. He has given us love when we deserve punishment. Forgiveness says, in effect, "I won't reject you for your failures. I choose to accept you fully just as you are and I won't remind you of your failures."1

Forgiveness stands with the open arms of a loving friend, ready to embrace. It is difficult for a mate to resist such complete and unselfish love.

According to walter wangerin, Jr., there are three elements that must be present in the act of forgiveness:
1. Giving up
2. Giving notice
3. Giving gifts. ${ }^{2}$

Forgiveness is a willing relinquishment of certain rights. The one sinned against chooses not to demand her

${ }^{1}$ Ibid.

${ }^{2}$ Walter Wangerin, Jr., As for Me and My House (Nashville: Thomas Nelson Publishers, 1987), 79. 
rights of redress for the hurt she has suffered. He does not hold his spouse accountable for her sin, nor enforce a punishment upon her, nor exact a payment or any reparations from her. She does not make his life miserable in order to balance accounts for her own misery, although she might feel perfectly justified in doing so. The act of forgiveness is inconsistent with a tit-for-tat approach. 


\section{THE PROCESS OF FORGIVENESS}

Beverly Flanigan in her book, Forgiving the Unforgivable, ${ }^{1}$ proposes six phases in the process of forgiveness:

1. Naming the injury

2. claiming the injury

3. Blaming the injurer

4. Restitution or balancing the scales

5. Choosing to forgive

6. The emergence of a new self.

${ }^{1}$ Beverly Flanigan, Forgiving the Unforgivable: overcoming the Bitter Legacy of Intimate Wounds (New York: Maxwell Publishing Company, 1992), 74 . 


\section{The Objective of Blaming}

To blame someone is, first of all, to hold that person responsible for causing an event to happen." "It is, second, to assert that the responsible person did something wrong. "2

People do not blame each other for good things, they blame each other when bad things happen. The story of Jonah is a good illustration of this. Because of Jonah's disobedience to the voice of the Lord, "the Lord sent a great wind on the sea, and such a violent storm arose that the ship threatened to break up" (Jonah 1:4, NIV). "The sailors said to each other, 'Come let us cast lots to find out who is responsible for this calamity." Jonah was responsible. Vs. 12 confirms this! "I know that it is my fault that this great storm has come upon you" (Jonah 7:12). Thus, blaming has two steps. First, you must decide who caused something to happen. Second, you must decide that the responsible person was wrong--that is, morally wrong. The person blamed has violated an accepted moral rule and is responsible for having done so. ${ }^{3}$ There is nothing bad or good about blaming. Blaming in its technical sense is holding someone morally accountable. ${ }^{4}$ Blaming

\footnotetext{
${ }^{1}$ Flanagan, 108 .

${ }^{2}$ Ibid.

${ }^{3}$ Ibid.

${ }^{4}$ Ibid.
} 
requires action. Taking action gives people some control over events in their lives. ${ }^{1}$ The first action towards blaming is for a wounded person to decide who exactly can be blamed for the injury. Who are the available "targets" of blame? ${ }^{2}$

In the case of Jonah, no one on the boat was responsible for the danger. It would have been morally wrong to blame anyone for the crisis. Only Jonah was to blame. Jonah was the available target.

Injured people need to be told that blaming is a positive step forward. But it is not, by any means, a place to land and stay; it is only a step on the way to healing. once you can blame, you know whom you must forgive.

I'Ibid., 108, 109.

${ }^{2}$ Ibid. 


\section{The Emergence of a New Self}

As Janet ${ }^{1}$ put it, "If something devastates your life, a complete reorganization begins. I needed a whole new philosophy about people." You remember the story of Nancy mentioned earlier. Nancy became a new person after she realized that she could no longer harbor ill feelings against her daughter's murderer.

The final phase of forgiving is called the emergence of the new self. It is in this phase that the word "forgiving" begins to make sense. The two parts of the word forgiving--"for" and "giving"--suggest the idea that a wound exists for the purpose of giving; in other words, wounds exist to give us a chance to give up one thing and begin something else. ${ }^{2}$

People who forgive choose not to dwell in the past but to look to the future. Jesus Christ, the source of forgiveness, forgave Peter for denying $\mathrm{Him}$. He encouraged him to move forward. "Feed my sheep. . . Feed my lambs" (John 21:15-17). Now that Peter was forgiven, there was a new task before him. He was to learn from, but not to live in, the past. The same holds true today both for those who choose to forgive and for the beneficiaries of the act of forgiveness.

In Rom 6:28, Paul says, "And we know that in all

${ }^{1}$ Real person but fictitious name.

${ }^{2}$ Flanigan, 162 . 
things God works for the good of those who love Him, who have been called according to His purpose." Some harm we can control; some we cannot. Remember the Serenity Prayer, "God grant me the serenity to accept the things I cannot change, the courage to change the things I can, and the wisdom to know the difference."

When you forgive a person who has hurt you, and that person may be your own partner, you say in reality:

Harm comes to every one; moral contracts cannot prevent injury; no one is immune from it, but a larger force (usually God) has a reason, however mysterious, for injuries that befall people. People may suffer, but the suffering has a larger purpose. The test of a person's character is how well he functions even when he cannot understand God's plan for him.'

${ }^{1}$ Dictionary of the Apostolic Church (1926), s.v. "forgiveness." 


\section{BIBLICAL FORGIVENESS}

\section{How to Forgive}

The Greek word for forgiveness is aphiemi. It is used often in the New Testament, especially in the Gospels, and means "send away from oneself" (Matt 13:36:); "let go" (Matt 4:20); "turn away" (Matt 19:29; 1 Cor 7:10); "pass over" or "neglect" (Heb $6: 1$ ).$^{1}$ Hence it is used in the sense of remitting a debt (Matt $18: 27 ; 6: 12,14$ ).

Forgiveness includes making of no account the sin which has been committed (Mark 2:5; John 8:11). It also means the acceptance of the sinner (Luke 15:20ff.). ${ }^{2}$ Christ taught not only the duty of forgiveness or repentance, but also that it was to be unlimited both in quality and quantity. No offense was so serious, no repetition of offense so excessive that forgiveness might be withheld, provided only that penitence was shown.

\section{Unlimited Forgiveness}

In Matt $8: 22$, Christ shows that Forgiveness is not a matter of mathematics or legal regulations, but an attitude. He who harbors within himself the idea that at some future time he will not forgive, is far from extending true forgiveness even though he may go

\footnotetext{
"forgiveness."

${ }^{2}$ The New International Dictionary of New Testament Theology, Vol. 1, 701 .
}

${ }^{1}$ Dictionary of The Apostolic Church (1926), s.v. 
through the form of forgiving. ${ }^{1}$

If the spirit of forgiveness activates the heart, a person will be as ready to forgive a repentant soul the eighth time as the first, or the 491 st time as the eighth. True forgiveness is not limited by numbers.

The theologian William Barclay states that "there is no reckonable limit to forgiveness." ${ }^{2}$ Alluding to the story of the debtor, Barclay further comments:

It teaches that lesson which runs through all the New Testament--a man must forgive in order to be forgiven. He who will not forgive his fellow men cannot hope that God will forgive him. "Blessed are the merciful" said Jesus, "for they shall obtain mercy." As James said, "For judgement is without mercy to one who has shown no mercy" (James 2: 13). Divine judgement and human forgiveness go hand in hand. ${ }^{3}$

If God has forgiven all, how much more should a man or woman be ready to forgive the partner who has done wrong!

Forgiveness in word and Action

Jesus prayed for those who crucified Him, "Father forgive them, for they know not what they do." He washed the feet of the one who was going to betray Him. He graciously pardoned Peter for his denial of Him, then He reincorporated him into the apostolic circle.

${ }^{1}$ Seventh-Day Adventist Bible Commentary, Vol. 5, (Washington, DC: Review and Herald Pub. Assn., 1956), 449.

${ }^{2}$ William Barclay, The Daily Study Bible: The Gospel of Matthew, (Toronto, Canada: G. R. Welch Co, 1975), 2:192.

${ }^{3}$ Ibid. , 194, 195. 
It was the French philosopher Moliere who wrote this: "Men are alike in their words, but their actions differentiate among them." Jesus, the source of forgiveness, did not merely utter the words "I forgive you" but by His actions He demonstrated the spirit of forgiveness.

Forgiveness, on the part of either God or man, is much more than a judicial act. It is a restoration of peace where there has been conflict (Rom 5:1). But it is even more than that. It includes the effort to restore the erring person himself (Gal 6:1). Applied to the marriage covenant, this idea implies that husbands and wives must pledge themselves to love each other unconditionally and to be always willing to overlook each other's frailties. Therefore I must be willing to forgive and accept my partner as long as I would like God to forgive and accept me. I am -very much in agreement with Bacchiocchi's explanation of forgiveness:

In a covenant marriage, we recognize the sin that our mates have committed against us. We don't explain away the sinful behavior of our mates by saying "He did not mean what he said," or "probably I deserve what he did to me" or "I don't feel really hurt by what he did to me." Rather, we realistically recognize that we have suffered wrong, but we don't allow such wrongs to weaken our mutual commitment. Why? First, because we recognize that we are sinful beings who sometimes hurt each other terribly. We violate the deepest trust of our mates. We trample upon their unconditional love. Secondly, because we realize 
that since God can forgive our mates; so can we. ${ }^{1}$

${ }^{1}$ Bacchiocchi, 115, 116. 


\section{COVENANT FORGIVENESS AS THERAPY}

Researchers Michael McCullough and Everett Worthington concisely define forgiveness as a complex combination of

effective cognitive and behavioral phenomena in which negative effect and judgement toward the offender are reduced, not by denying one's right to such effect and judgement, but by viewing the offender with compassion, benevolence and love, while realizing that the offender has no right to them.

In their research studies on forgiveness, Mccullough and Worthington were able to demonstrate that forgiveness can lead to restored relationships and to restored peace of mind for both partners. When people forgive, there are decreased feelings of revenge, more positive feelings among every one involved, and more efforts to bring about reconciliation.' Richard Nixon once said, "When you hate others and refuse to forgive, you are the one who really loses in the end. When there is forgiveness between people, the forgiver and the offender both benefit."

In his book, Stress Without Distress, Dr. Hans Selye, recognized as the world's foremost authority on stress, has stated that hate causes stress and love eliminates it. He asks, "If everyone loved his neighbor as himself, how could there be any war, crime, aggression or

${ }^{1}$ Gary R. Collins, The Biblical Basis of Christian Counselling for People Helpers (Colorado Springs: NavPress, 1984), 146 . 
even tension among people?"1

The problem, wrote Dr. Selye, is that, "if we don't somehow modify our built-in selfishness, we arouse fear and hostility in other people."2

Professor Jean Monbourquette recounts an incident of forgiveness as therapy:

I was an eyewitness to a psychological, indeed a physical healing which followed an exercise of forgiveness. I received in therapy a university professor of deep faith. His industrious attitude and his marital problems brought him to the brink of depression. Furthermore he was suffering from ulcers. I asked him to admit his frustration, his anger against his alcoholic wife, his son (a victim of drugs), and his daughter's infatuation with a young man whom he detested. I suggested to him to forgive each of them. Two weeks later the university professor announced that he had no more ulcers and that his health was drastically improved. ${ }^{3}$

In his book, Loving Each Other, ${ }^{4}$ Leo Buscaglia recounts another cure of forgiveness. It concerned a husband and wife who had gone to a prison to embrace, in forgiveness, a man who had raped and murdered their twentytwo-year-old daughter. Bob and Goldie Bristol told of the horror and pain they felt on learning of their daughter's murder. They revealed their eventual decision to leave

$$
\begin{aligned}
& \text { 'Selye, } 35 . \\
& { }^{2} \text { Ibid. }
\end{aligned}
$$

${ }^{3} J e a n$ Monbourquette, Comment Pardoner (Ottawa, Canada: Novalis Centurion, 1992), 12, 13. (translation by Vaudre Jacques).

${ }^{4}$ Leo Buscaglia, Loving Each other (NJ: Slack, 
retribution to heaven. Fortified with a deep sense of religious faith, they decided to embrace their enemy in love. After many attempts to reach Tom (the fictitious name they assigned to their daughter's slayer), he finally agreed to see them. Mrs. Bristol described their meeting in prison in touchingly simple language:

The door opened, Tom entered the room. He was about six feet tall, dark haired and muscular, cleanly dressed and shaven. . . A person. God's love welled up within me and overflowed. Tom paused, his eyes filled with tears. My husband and $I$ stood and each in turn embraced Tom. We wept together. ${ }^{1}$

She frankly admitted that they did not understand the "why" of his brutal action. They simply allowed themselves to experience his humanness--the aspect of Tom they were able to identify with, understand, and accept.

After their meeting, they felt free, purged of anger and resentment. Even their pains disappeared. ${ }^{2}$

Asking for forgiveness and forgiving others are complicated processes that involve deep sympathy, humanity, and wisdom. Historically, we have found that without forgiveness there can be no lasting love, no change, no real growth, no freedom. ${ }^{3}$ Dr. Gerald Jampolsky is right when he states: "Hate, bitterness and vindictiveness are overpowering, self-defeating and intellectually as well as

\footnotetext{
${ }^{1}$ Ibid.

${ }^{2}$ Ibid., 94 .

${ }^{3}$ Ibid. , 95.
} 
emotionally depleting."1

Again, the question arises: Why should we forgive? We forgive, for the price we pay for not forgiving is too great. To bear grudges, to harbor hate, to seek revenge, are all self-defeating and lead us nowhere. They neither satisfy nor heal. They keep us from moving forward and starting again. They bury positive energies in negative actions which serve only to exhaust and deplete us. They keep us suspicious and hesitant to trust again. They destroy our creativity, and retard our growth. ${ }^{2}$

It is certainly for this therapeutic benefit that Jesus instructed His followers to forgive (Luke 17:4). On another occasion, He spoke with disapproval about the servant who was forgiven a large debt, but then refused to forgive the much smaller debt of a fellow servant (Matt $18: 23-35)$

The aim of forgiveness is reconciliation, God does not want brothers and sisters to live in estrangement. As Roberts puts it:

The aim of Christian forgiveness is not to rid the forgiver of an unpleasant and disruptive emotion but to strive toward the attitudes and relationships characteristic of God's Kingdom. Forgiveness is therapy, and love is the health at which it aims. ${ }^{3}$

Jesus is very specific in Matt 6:12: "Forgive us our debts, as we also forgive our debtors." We need to receive forgiveness and to extend forgiveness to others. Someone writes, "I made a distinction between

${ }^{1}$ cited in ibid.

${ }^{2}$ Ibid., 104

${ }^{3}$ See Robert C. Roberts, 199. 
forgiving in the head and forgiving in the heart. Not to forgive in your heart destroys your health and your heart. People should know, though, that it is hurdle after hurdle." Another person declares: "Not to forgive means not being the person you want to be. Not forgiving can do terrible things to a person. It changes you."

Janet wrote:

Forgiveness is a virtue, I think. Anger brings you nothing. No sleep, no smiling. Then it spurts out into other areas. . . God doesn't want us to be miserable mentally or physically. If you are harboring anger or wanting revenge, you are not doing God's will for you. You are not allowing yourself to be the person God wants you to be. Forgiveness is a fantastic way to live. It releases you from so much. You can never again be so angry. Never as intense. Never for so long. I think it's one of the most important things to be able to do. It is accepting the fact that no one is perfect. ${ }^{1}$ 


\section{TECHNIQUES FOR ENHANCING MARITAL COVENANT LOVE}

Dr. Hans Selye, in his book Le stress sans Détresse, remarks that "whatever is the problem, we cannot face it but by one of two fundamental types of reaction: Actively, struggling with it, or positively, by running from it."1

Dr. M. Scott Peck echoes Selye's statement when he says that

life is a series of problems. Do we want to mourn about them or solve them? Problems are the cutting edge that distinguishes between success and failure. Problems call forth our courage and our wisdom; indeed they create our courage and our wisdom. It is only because of problems that we grow mentally and spiritually. It is through the pain of confronting and resolving problems that we learn.2

Building love is a creative process, much more like painting a picture or playing a symphony than performing a mechanical function. Love will increase if both partners have or learn certain skills. Here are eleven techniques that can help build up marital love. These techniques are numerous and are not exhaustive, but the following ones are a good start.

1. Don't keep score.

2. Renew your marital commitment toward each other.

3. Take time alone to identify what each of you needs in order to feel loved.

${ }^{1}$ Dr. Hans Selye, Le stress sans Détresse (New York: J. B. Lippincott Co., 1974), 18, translation mine.

${ }^{2}$ Dr. M. Scott Peck, The Road Less Traveled (New York: Simon and Schuster, 1978), 15. 
4. Decide which of your desires are reasonable.

5. Understand that your needs and your partner's needs are not identical.

6. Take turns expressing and listening to each other's desires, attempting simply to understand, not to change them.

7. Identify which desires each is willing and able to satisfy.

8. Be consistent and fair.

9. Learn to express love and affection verbally.

10. Build your partner's self-esteem by giving and receiving positive feedback.

11. Control your anger.

Remember, the success of the marital relationship depends, to a large extent, on the degree to which both partners are committed to making it happen. Now, let us take a closer look at each of the eleven techniques. 
Technique 1. Recognize that love does not keep score. Sharing in love does not mean keeping a balance sheet of who is doing what and who is doing more. There will be times when we must give more than we get, but there will be other moments when we will need and receive more than we are able to give. Keeping score belongs in competitive sports, not in a mutually supportive relationship. True love is wanting to give to another person without any thought about who is getting the better of the deal. The idea that love involves some sort of quid pro quo is, at best, evidence of immaturity that needs to be outgrown. At worst, it is a distortion of love that turns two people into unhappy combatants vying for control.

Technique 2. Renew your marital commitment to love each other. Donovan and Ryan point out:

It is the nature of the human psyche to seek relationships that involve commitment and thus provide a sense of permanence and security. People need to know that no matter what happens, they have a home base they can always return to for love, acceptance and care. ${ }^{1}$

Although some people have a greater need for security than others, everyone has some need for a person or persons to "be there" for them and not just today or tomorrow, but also in the times ahead. ${ }^{2}$

The security of having a solid home base is what

\footnotetext{
${ }^{1}$ Ibid. , 240.

${ }^{2}$ Ibid.
} 
enables an individual to venture out into the world alone; without it, the world may seem more intimidating than exciting.

Technique 3. Take time alone to identify what each of you needs in order for you to feel loved. This technique requires that both partners grow to know themselves enough to understand what experiences are pleasurable to them. In fact, a delicate balance of the ability to give and the ability to receive is required. Many of us have experienced the frustration of trying unsuccessfully to satisfy a lover. often this happens because the lover has failed to identify what would give satisfaction. Naturally, then, the first step to love enhancement requires that both partners know themselves and what they expect from the relationship. ${ }^{1}$

The key to this technique is to identify very clearly how your partner can act to meet your need. Too often, needs are left either unstated or stated so generally that your partner remains at a loss to know just what to do in order to fulfill your requests. ${ }^{2}$ Be specific and polite.

Technique 4. Decide which of your own desires are reasonable. While you are alone, go through your list of wants. Mark an " $R$ " beside those you feel are realistic wishes, an " $M$ " beside those that might be worth discussing

'John Wright, La Survie Du Couple (Montreal, Quebec: Les Editions La Presse LTÉE, 1985), 76.

${ }^{2}$ Braiker, 193. 
with your partner, and a "U" beside those you know are unrealistic. ${ }^{1}$

Technique 5. Accept that your needs and your partner's needs are not identical. You must be prepared to discover that your desires and your partner's are not identical. ${ }^{2}$

Jacqueline said, "I just want Robert to be close to me sometimes. I don't want to do anything else." Communication about each partner's list of desires will be productive, provided differences are seen as healthy rather than threatening to the relationship.

Remember, it takes mutual good will, comprehension, and tenderness for couples to resolve the unavoidable difficulties of life.

Technique 6. Take turns expressing and listening to each other's desires, attempting simply to understand, not to change them. ${ }^{3}$ I'om Rusk, in his book The Power of Ethical Persuasion, ${ }^{4}$ outlines seven steps in exploring alternative approaches for problem-solving. I think these steps can be applied to technique 6 .

a. Establish that your immediate goal is mutual

\footnotetext{
${ }^{1}$ Wright, 79.

${ }^{2}$ Ibid., 80 .

${ }^{3}$ Ibid.

${ }^{4}$ Tom Rusk, The Power of Ethical Persuasion (New
} York: Penguin Group, 1993), 70-73. 
understanding, not problem-solving.

b. Elicit the other person's thoughts, feelings, and desires about the subject at hand.

c. Ask for the other person's help in understanding him or her. Try not to defend or disagree.

d. Repeat the other person's position in your own words to show you understand.

e. Ask the other person to correct your understanding and keep restating his or her position.

f. Refer back to your position only to keep things going.

g. Repeat steps 1 through 6 until the other person unreservedly agrees that you understand his or her position.

Technique 7. Identify which desires each is willing and able to satisfy.

Technique 8. Be consistent and fair. Dr. Samuele Bacchiocchi says it nicely:

Couples who are committed to preserving their marriage covenants will not engage in "dirty fighting," hitting below the belt, or trying to win the argument. Paul alludes to this principle in Ephesians 4:25 where he says, "Therefore putting away falsehood, let everyone speak the truth with his neighbor, for we are members one of another..." Thus, a literal translation would read: Having put away falsehood, let everyone speak truthfully with his neighbor. ${ }^{1}$

Technique 9 . Learn to express love and affection

${ }^{1}$ Bacchiocchi, 109. 
verbally. Affectionate words, compliments, tokens of appreciation, and sharing positive feelings can be rich and satisfying ways to exchange affection. However, we must learn to express our feelings verbally. ${ }^{1}$

Technique 10. Building your partner's self-esteem by giving and receiving positive feedback. When a relationship turns toxic, communication is often restricted to a negative feedback cycle. This means that you both may be mired in giving and receiving criticism or expressing anger, demands, bitterness, and even insults. Or perhaps you are simply ignoring each other. This technique is designed to break the negative feedback cycle and replace it with positiveness. ${ }^{2}$

This is what one writer had to say about the importance of self-esteem:

Life would, no doubt be easier if we were all given a large dôllop of self-esteem. If we generally feel good about 'burs̀elves, have a number of supportive people in our lives, and have some sense of purpose, we can overcome those intermittent feelings of isolation and emptiness. We learn to emphasize the successes and rewarding relationships we have. On the other hand, if the positive attributes of our lives are insufficient or lacking altogether, it becomes increasingly difficult to maintain appearances and to continue functioning in a responsible, productive, caring manner. It is very difficult to maintain a positive facade if underneath you are feeling empty or in pain. ${ }^{3}$

${ }^{1}$ Wright, 80 .

${ }^{2}$ Braiker, 194 .

${ }^{3}$ Saul Levine, M.D., Rebuilding Shattered Lives (Toronto, Canada: Key Porter Books, 1992), 3 . 
Samuel L. DeShay, M.D., and Bernice A. DeShay, R.N., propose the following techniques that can help bolster selfesteem.

a. Avoid discussions and situations that you know will lead to tension or irritation.

b. Take a casual, leisurely walk outdoors, away from all the hustle and bustle.

c. Lighten up--learn to laugh at yourself and at circumstances that normally upset you.

d. Try to look on the lighter side and associate with happy people.

e. Smile--even when you are alone.

Technique 11. Control your anger. A Chinese proverb states that "if you are patient in one moment of anger, you will escape a hundred days of sorrow."1

Why should a couple control their anger? Because marital satisfaction is lowest when a spouse uses emotional manipulative strategies on his or her partner. Moreover, "anger is the emotion that fuels violence. . . A society like ours, which urges the expression of anger, sanctions it, and makes movies about its virtues, is a violent society." 2

There is no doubt about it, anger damages a marital

${ }^{1}$ Martin E. P. Seligman, what You Can Change and what You Can't (New York: Alfred A. Knopf, 1993), 127.

${ }^{2}$ Ibid., 120 . 
covenant love relationship. According to Martin E. P. Seligman, anger has three components:
a. There is a thought, a very discrete and particular thought: "I am being trespassed against." often, events get out of hand so quickly that you will not be conscious of this thought. You may simply react--but the thought of trespass is lurking there nonetheless. 
FOUR ESGENTIAL ELEMENTS TO MATURITY

The process of spiritual growth requires four elements analogous to those necessary for physical growth. I wish to illustrate these analogies through the following table:

\section{Table 1}

Spiritual Growth Elements

Needs of Healthy Body

Food, water

Air

Exercise

Rest
Needs of Christian Life

Daily portion of God's word

Submission to the Holy Spirit

Service to Christ

Worship before God's throne

Especially in this materialistic and religiously confused age, God seeks committed husbands and wives and godly families to worship Him. Christ said it a long time ago to the woman of Samaria:

The hour is coming, and now is, when the true worshippers will worship the Father in Spirit and in truth, for such the Father seeks to worship Him (John $4: 23$ ).

It is impossible to develop spiritual maturity without the presence of all of these factors. 


\section{THE CHARACTERISTICS OF THE SPIRITUALIY MATURE PERSON}

In his book Christian Counselling, Dr. Gary Collins writes: "The spiritually maturing Christian shows a desire to be like Christ, accompanied by some evidence of the fruits of the spirit in his or her life."1

Then Dr. Collins provides some guidelines for maturity. As one matures there is usually:

- A tendency to behave according to one's age (and not like someone older or younger).

- A capacity to assume responsibility.

- An ability to look at oneself and one's problems objectively.

- An ability to acknowledge but control emotions.

- An understanding of other people's feeling and a sensitive ability to respond to these emotions.

- A growing independence from the control of family and friends.

- A willingness to postpone immediate gratification so that greater satisfaction can be attained in the future.

- A responsible attitude towards sex.

- An ability to laugh and see the humorous side of life without tearing others down or resorting to criticism.

- A realistic and essentially positive self-image.

- An ability to make choices and live with the consequences of one's decisions. ${ }^{2}$

'Gary collins, Christian counselling: A Comprehensive Guide (Dallas: Word Publishing, 1988), 384 .

${ }^{2}$ Ibid. , 364, 385 


\section{THE LADDER OF CHRISTIAN MATURITY}

Gal $5: 22,23$ constitutes a guideline for christian maturity. In this passage we find the enumeration of the fruit of the spirit. "But the fruit of the spirit is love, joy, peace, patience, kindness, goodness, faithfulness, gentleness and self-control. Against such things there is no law."

The absence of these Christian graces in marital life impedes growth both in the home and in the church. In Gal 5:19-21, Paul condemns the whole nature of man as producing nothing but evil and worthless fruits. So he now tells us that all virtues, all good and well-regulated affections, proceed from the spirit, that is, from the grace of God and the renewed nature that we have from christ.

Love. We can see from figure 1 that the apostle places love at the top of the ladder. Love is the first fruit of the spirit. Therefore, love, as the term is used in the Greek New Testament, is now examined briefly and, in turn, the other fruits of the spirit. 
$-306$

LOVE

JOY

PEACE

PATIENCE

KINDNESS

GOODNESS

FAITHFULNESS

GENTLENESS

SELF-CONTROL

Figure 1. Growth Ladder 


\section{AGAPE}

STORGE

PHILEO

\section{EROS}

Figure 2. Kinds of love.

Joy means cheerfulness towards our fellow human beings and is the opposite of sadness.

Peace can be contrasted with quarrels and contentions.

Longsuffering or Patience gentleness of mind, which disposes us to take everything in good spirit and not be easily offended.

Gentleness and Kindness means mild of temper, calm, and quiet in disposition. A Christian is never to be morose or sullen, but ever-cheerful, thoughtful of others, and courteous. 1

Goodness/Faithfulness is a quality of conduct that gives others reason for confidence in us. Faith is a mental attitude, faithfulness, or a pattern of conduct.

Meekness is the attitude of heart and mind and life that prepares the way for satisfaction. A "meek" spirit is, in the sight of God, of a great price (1 Pet 3:4).

"Acts to Ephesians" SDA Bible commentary, ed. F. D. $6: 982$. 


\section{SEVEN GUIDELINES FOR ATTAINING CHRISTIAN MATURITY}

\section{Trust in the Lord}

Trusting in the name of the Lord and attachment to the Triune God is the first step to attaining Christian maturity. Ellen G. White states:

Jesus rested upon the wisdom and strength of $\mathrm{His}$ Heavenly Father. He declares, "The Lord God will help me; therefore shall I not be confounded: - . and I know that I shall not be ashamed. - . Behold, the Lord God will help me." Pointing to His own example He says to us, "who is among you that feareth the Lord.. . that walketh in darkness, and hath no light? Let him trust in the name of the Lord, and stay upon his God" (Isa $50: 7-10) \cdot 1$

Mrs. White continues:

So it may be with us. Christ's humanity was united with divinity. He was fitted for the conflict by the indwelling of the Holy spirit. And He came to make us partakers of the divine nature. So long as we are united in Him by faith, sin has no more dominion over us. God reaches for the hand of faith in us to direct it to lay fast hold upon the divinity of christ, that we may attain to perfection of character. ${ }^{2}$

The Christian couple has the promise of God's help to them in the vicissitudes of life today. "Never will I leave you; never will I forsake you" (Heb 13:5).

\section{Living in the Present and Pressing on}

It is characteristic of a growing person to be present in the here and now rather than focusing on the past. It is also a mark of maturity to keep on moving.

${ }^{1}$ Ellen G. White, The Desire of Ages (Mountain View, CA: Pacific Press, 1940), 123.

${ }^{2}$ Ibid. 
Life is like a bicycle. You must continue pedalling, in order to move forward. When you live in the present, you do your best to hear what others are saying and the way they are saying it. When you respond, you do so in a congruent way. John Bradshaw notes:

Congruence means that the content (the words we say) is consistent with the process (the way we say the words), our tone of voice, facial expression, body posture, etc. Congruence allows for real contact. Mystified people tend to be either confused with others or in conflict with them. ${ }^{1}$

It is my contention that living in the present is vital in overcoming the conflicts of the past and striving for a better future. Here is the Apostle Paul's sound advice:

Not that I have already obtained this or am already perfect; but I press on to make it my own, because Christ Jesus has made me His own. . . . But one thing I do, forgetting what lies behind and striving forward to what lies ahead, I press on toward the goal for the prize of the upward call of God in Christ Jesus (Phil 3:12-14).

\section{A Commitment to Loving God and Partner}

Love for God and for one's partner cannot happen unless one is willing to commit oneself to making it happen. That love is a process that requires hard work and courage. It is true that all of Christ's strength is my strength, provided that I am willing to abide and remain in Him (John $15: 4,5)$. In other words, I must make a choice.

'John Bradshaw, creating Love (New York: Bantam Books, 1992), 127. 
I must choose to make Christ central in my life.

\section{A Willingness to Face Reality}

If a couple wants to experience maturity in their marital relationship, they must realize that each must change and adapt to the other. We all have things to learn about relationships and most of us have habits that prevent our being happy with our partners.

\section{A Willingness to Admit Mistakes and Learn from}

Them

A growing person learns from his or her mistakes.

Janet Moursund points out:

The real mistake lies not in committing an error, but in failing to learn from it. Every mistake can be the signal for a new step toward therapeutic competence, if it is recognized, analyzed and used for growth. Don't be complacent about your mistakes. They are not good, and nobody likes to make them. However, don't magnify them out of proportion, either. Like rocks in a stream, they can be used to trip and fall over or as a bridge to a new and better place. ${ }^{1}$

Make sure that your decisions are not based on emotions and coercion but rather on truth, reason, and persuasion. Be prepared to change your mind when the evidence indicates that you should.

6. A Willingness to Practice Self-Examination

A spiritually mature person practices selfexamination. It was Socrates who posed what is the philosopher's Magna Carta with his maxim: "The unexamined

\footnotetext{
'Janet Moursund, The Process of Counselling and
} Therapy (New Jersey: Prentice Hall, 1990), 213. 
life is not worth living." In his turn, Paul wrote to the Corinthians: "Examine yourselves to see whether you are holding to your faith. Test yourselves" (2 Cor 13:5). This is a plea for self-examination whether in marital life or in the church. For your own salvation and for the salvation of your partner and family, you have an obligation to do your share to help your marriage work, and a further obligation to eradicate from your life, by God's grace, bad attitudes or habits in order to make your marriage a success. Do not refuse to invest the time and effort to improve the chances of making your marriage work. In your introspection, ask yourself the following questions: a. "Is there anything I can do that would enhance my marital covenant love relationship?" This question invites us to look at what we really want to have and to change.

b. "What would I need to change in order to get what I want?" Do not make success contingent upon someone else's behavior, but you can determine how you are going to react.

c. "Are there any changes I could make in myself that would enhance my life?"

d. "What would I be willing to do to effect the change?"

In Rom 13:11-14 Paul wrote:

Besides this, you know what hour it is, now it is full time for you to wake from sleep. For 
salvation is nearer to us now than we first believed. The night is far gone, and the day is at hand. Let us then cast off the works of darkness and put on the armor of light, let us conduct ourselves becomingly as in the day, not in revelling and drunkenness, not in debauchery and licentiousness, not in quarreling and jealousy, but put on the Lord Jesus Christ, and make no provision for the flesh, to gratify its desire (RSV).

Here Paul is telling us about kairos time. The word we use for "time" or "knowing the time" does not refer to time in general but a time with distinct significance, a time charged with issues of practical moment. 
How to Go About It

In using your kairos time with God to strengthen both your marriage and your christian experience, you must ask these questions: Lord, what do you want me to do? What should I do? Then:

1. Wait on the Lord: "Lord, speak, your servant listens."

2. Pray to become like Jesus. Only the grace of God will enable you to love your wife as christ loves the church.

3. Pray for purity of heart.

4. Pray for spousal commitment on your part. A spousal commitment includes some or all of the following decisions :

a. "To be committed to continuous personal growth and to support your partner's personal growth." b. "To affirm your partner's strengths and be willing to be patient, to forgive, and negotiate conflict and differences." 


\section{ANGER INVENTORY ${ }^{1}$}

Read each statement and then mark the appropriate number to indicate how you generally feel. There are no right or wrong answers. Do not spend too much time on any one statement, but give the answer that seems to describe how you generally feel.

1. I am quick-tempered.
Almost never
1
Sometimes
2
$\underset{3}{\text { Often }}$
Almost always
4

2. I have a fiery temper.
Almost never
1
Sometimes
2
$\underset{3}{\text { Often }}$
Almost always
4

3. I am a hotheaded person.
Almost never
sometimes
1
2
often
3
Almost always
4

4. I get angry when I am slowed down by others' mistakes. $\begin{array}{rccc}\text { Almost never } & \text { Sometimes } & \text { Often } & \text { Almost always } \\ 1 & 2 & 3 & 4\end{array}$

5. I feel annoyed when I am not given recognition for doing good work.
Almost never
1
Sometimes
2
Often
3
Almost always
4

6. I fly off the handle.
Almost never
1
Sometimes
Often
Almost always
2
3
4

7. When I get mad, I say nasty things.
Almost never
1
Sometimes
often
3
Almost always

8. It makes me furious when I am criticized in front of others.
Almost never
1
Sometimes
often
3
Almost always
2
3
4

9. When I get frustrated, I feel like hitting someone.
Almost never
1
Sometimes
2
often
3
Almost always
4

${ }^{1}$ Developed by Charles spielberger in collaboration with G. Jacobs, R. Crone, S. Russell, and I. Wesberry. 
10. I feel infuriated when I do a good job and get a poor evaluation.
Almost never
1
Sometimes
2
Often
Almost always
4

8coring. Simply add the numbers attached to your answers for the ten questions. The higher your total, the more anger dominates your life.

If you scored 13 or below, you are in the least angry

10 percent of people.

If you scored 14-15, you are in the lowest quarter.

If you scored 17-20, your anger level is about average.

If you scored 21-24, your anger level is high, around the seventy-fifth percentile.

If you scored 29-30 and you are male, your anger level is around the ninetieth percentile.

If you scored 25-27 and you are female, your anger

level is around the ninetieth percentile.

If you scored above 30 and you are male, your anger

level is at the most hotheaded ninety-fifth percentile.

If you scored above 28 and you are female, your anger

level is at the ninety-fifth percentile.

People mellow as they age. If you are under twentythree years old, a score of 26 or more puts you in the most angry 10 percent. But if you are over twenty-three years old, a score of only 24 or more puts you with the top 10 percent. If you scored in the top half of the anger inventory, anger is an emotion with shich you are quite familiar. 


\section{BIBLIOGRAPHY}




\section{BIBLIOGRAPHY}

Achtemeier, Elizabeth. The Committed Marriage. Philadelphia, PA: Westminster Press, 1976.

Adams, Jay E. Christian Living in the Home. Nutley, NJ: Presbyterian and Reformed Publishing Co., 1972.

- The Christian Counselor's Manual. New Jersey: Phililpsburg Reform Publishing Co., 1973.

Atkinson, David. To Have and To Hold--The Marriage covenant and the Disciple of Divorce. Grand Rapids, MI: Eerdmans, 1979.

Bacchiocchi, Samuele. The Marriage Covenant. Berrien Springs, MI: Biblical Perspectives, 1991.

Balswick, Judith K. Toward A Practical Theology of Marital Sexuality. N.p.

Barclay, William. The Daily Study Bible: The Gospel of Matthew. Vol. 2. Toronto, Canada: G. R. Welch Co., 1975 .

Bradshaw, John. Creating Love: The Next Great Stage of Growth. New York: Bantam Books, 1992.

Braiker, Harriet B. Lethal Lovers and Poisonous People:

How to Protect Your Health From Relationships That Make you Sick. New York: Pocket Books, 1992.

Brunner, Emil. Man in Revolt: A Christian Anthropology.

Philadelphia: Westminster, 1939.

Buscaglia, Leo. Loving Each Other: The Challenge of Human Relationships. New Jersey: Slack, 1984. - Born for Love: Reflections on Love. USA:

Random House, 1992.

Calvin, John. Calvin's New Testament Commentaries. Grand Rapids, MI: Eerdmans Publishing Co., 1979.

Chambers, Peter. Made in Heaven. London: N.p., 1988. 
Clinebell, Howard J., Jr. Basic Types of Pastoral Counseling. Nashville: Abingdon Press, 1966.

Collins, Gary R. Christian counseling: A Comprehensive Guide. Dallas: Word Publishing, 1988.

- The Biblical Basis of Christian Counseling for People Helpers. Colorado Springs: NavPress, 1984 .

Deshay, Samuel L., and Bernice A. Deshay. 15 Days to Lower Blood Pressure and Cholesterol. Pleasant View, TN: Upward Way, 1990.

Dictionary of the Apostolic Church.

Donovan, Mary Ellen, and William P. Ryan. Love Blocks: Breaking the Patterns That Undermine Relationships. New York: Penguin Group, 1989.

Dunstan, G. R. Theology 78, no. 659, May 1975.

Eadie, John. A Commentary on the Greek Text of the Epistle of Paul to the Ephesians. Grand Rapids, MI: Baker Book House, 1979.

Eichrodt, Walter. Theology of the old Testament. Philadelphia: The Westminster Press, 1960.

Exegetical Dictionary of the New Testament. Grand Rapids, MI: Wm. B. Eerdmans Publishing Co., 1990.

Feinberg, Charles I. The Minor Prophets. Chicago: Moody Press, 1980.

Flanigan, Beverly. Forgiving the Unforgivable: overcoming the Bitter Legacy of Intimate Wounds. New York: Maxwell Publishing Co., 1992.

Friedsen, DeLoss D. and Ruby M. Friedsen. Counseling and Marriage. Vol. 19. Dallas: Word Publishing, 1989.

Getz, Gene A. The Christian Home in a Changing world. Chicago: Moody Press, 1972.

Gordis, Robert. Love and Sex: A Modern Jewish Perspective. New York: McGraw-Hill Ryerson, 1978.

Harrison, Roland Kenneth. Introduction to the old Testament. Grand Rapids, MI: Wm. B. Eerdmans Publishing Co., 1969. 
Hartman, Louis. Encyclopaedic Dictionary of the Bible. New York: McGraw Hill, 1963.

Hastings, J., ed. "Forgiveness." Dictionary of the Apostolic Church, vol. 11. New York: 1926.

Hendrix, Harville. Keeping the Love You Find. New York: Pocket Books, 1992 .

Hulme, Lucy, and William Hulme. Practicing Marriage. Philadelphia: Fortress Press, 1987.

Interpreter's Dictionary of the Bible. New York: Abingdon Press, 1962 .

Johnson, David W., and Frank P. Johnson. Joining Together: Group Theory and Group Skills. Englewood Cliffs, NJ: Prentice-Hall, 1991.

Kelly, William Doane, quoted in Louis Hartman, Encyclopaedic Dictionary of the Bible. New York: McGraw-Hill Publishing Co., 1963.

Kistler, Robert c. Marriage, Divorce, and... Edited by Raymond H. Woolsey. Washington, DC: Review and Herald Pub. Assn., 1987 .

Kittel, Gerhard, and Gerhard Friedrich. Theological Dictionary of the New Testament. Vol. 1. Grand Rapids, MI: Wm. B. Eerdmans Pub. Co., 1994.

Lanares, Pierre. Les secrets de L'Amour. Dammarie les Lys, France: Editions SDT, 1975.

Levine, Saul, M.D. Rebuilding shattered Lives. Toronto, Canada: Key Porter Books, 1992.

Mace, David, and Vera Mace. The Sacred Fire: Christian Marriage Through the Years. Nashville: Abingdon Press, 1987.

Mayhall, Jack, and Carole Mayhall. Marriage Takes More Than Love. Colorado Springs: Navpress, 1978.

Monbourquette, Jean. Comment Pardoner. Ottawa, Canada: Novalis Centurion, 1992.

Moursand, Janet. The Process of Counselling and Therapy. Englewood Cliffs, NJ: Prentice-Hall, 1990.

Murray, John. The Epistle to the Romans. Grand Rapids, MI: Wm. B. Eerdmans Pub. Co., 1977. 
Nelson's Expository Dictionary of the Old Testament. Nashville: Thomas Nelson Publishers, 1980.

The New International Dictionary of New Testament Theology. Grand Rapids, MI: 1975.

New International Dictionary of New Testament Theology. Vol. 1. Edited by Collin Brown. Exeter: Devon, 1975.

Osborne, cecil. The Art of Understanding Your Mate. Grand Rapids, MI: Zondervan Publishing House, 1970.

The Ottawa Citizen, Sunday, May 15, 1994.

Peck, M. Scott, M.D. The Road Less Traveled. New York: Simon and Schuster, Inc., 1978.

Rainey, Dennis, and Barbara Rainey. Building Your Mate's Self-Esteem. San Bernardino, CA: Here's Life Publishers, 1966.

Rayburn, Robert G. o come, Let Us Worship. Grand Rapids, MI: Baker Book House, 1980.

Rekers, George A. Counseling Families. Waco, TX: Word Books, 1988 .

Roberts, Chalion O'Hearn, and William P. Roberts. Partners in Intimacy: Living Christian Marriage Today. New York: Pantist Press, 1988.

Roberts, Robert $c$. Taking the Word to Heart: Self and other in an Age of Therapies. Grand Rapids, MI: Wm. B. Eerdmans Pub. Co., 1993.

Robertson, 0. Palmer. The christ of the covenants. Grand Rapids, MI: Baker Book House, 1980.

Rusk, Tom. The Power of Ethical Persuasion. New York: Penguin Books, 1993.

Schillebeeckx, Edward. Marriage. London: Sheed and Ward, 1965 .

Seligman, Martin E. P. What You Can Change and What You Can't. New York: Alfred A. Knopf, 1993.

Sel1, Charles M. Achievement the Impossible: Intimate Marriage. Portland, OR: Multnomah Press, 1978.

Sellner, Judith A., and James G. Sellner. Loving for Life. North Vancouver: Self-Counsel Press, 1991. 
Selye, Hans. Stress Without Distress. New York: J. B. Lippincott Co., 1974 .

Seventh-day Adventist Bible Commentary. Mountain View, CA: Pacific Press Publishing Assn., 1956.

Seventh-day Adventist Minister's Manual. Silver Spring, MD: General Conference of Seventh-day Adventists, 1992.

Southard, Samuel. Theology and Therapy. Dallas: Word Publishing, 1989 .

Swindoll, Charles. Strike the original Match: Rekindling and Preserving Your Marriage Fire. Portland, OR: Multnomah Press, 1980.

Thomas, John L. Beginning Your Marriage. Chicago, IL: ACTA Publications, 1987.

Timmones, Tim. Maximum Marriage. New Jersey: Fleming $H$. Revell Co., 1976.

Tracy, Brian. Maximum Achievement. New York: Simon and Schuster, 1993.

Wangerin, Walter, Jr. As For Me and My House. Nashville, TN: Thomas Nelson Publishers, 1987.

Warren, Bennis. On Becoming a Leader. Addison, IL: Wesley Publishing Co., 1989.

Weisse, Allen B. The Man's Guide to Good Health. Yonkers, NY: Consumer Report Books, 1991.

White, Ellen G. The Desire of Ages. Mountain View, CA: Pacific Press Pub. Assn., 1940.

Wright, John. La Survie Du Couple. Montreal, Quebec: Les Editions La Presse LTEE, 1985.

Wynne, Lyman C., and Adele R. Wynne. "The Quest for Intimacy." Journal of Marital and Family Therapy 12 October 1986):383. 


\section{VITA}

Personal and Family:

Name:

Date of Birth: Place of Birth: Wife's Name: First Child: second Child:
Vaudré Pierre Jacques

June 10,1946

Cap-Haitien, Haiti

Gladys Brutus Jacques

Danielle Jacques

Patrick Elie Jacques

Educational Accomplishments:

Bachelor of Theology, Canadian Union College, College Heights, Alberta 1978

Master of Divinity, Andrews University, USA 1982

Doctor of Ministry, Andrews University, USA 1995

Professional Accomplishments:

1976 (Summer) Assistant Publishing Department Quebec Conference

1977 (Summer) Assistant Publishing Department Manitoba, Saskatchewan Conference

1978-1979 Internship, Winnipeg, Manitoba Saskatchewan Conference

1981-1986 District Pastor, Swan River, Hudson Bay

1986-1991 Responsible for the French Work

1991 ottawa, Ontario Conference

1994 District Pastor, Ottawa Est, Ontario Conference District Pastor, Ottawa Est, ottawa French, Ontario Conference 